\title{
Archeological Survey of Wildlife Mitigation Lands, Justiceburg Reservoir, Garza County, Texas
}

\author{
Douglas K. Boyd \\ Prewitt and Associates, Inc. \\ C. Britt Bousman \\ Department of Anthropology, Texas State University \\ Martha Doty Freeman \\ Prewitt and Associates, Inc.
}

Follow this and additional works at: https://scholarworks.sfasu.edu/ita

Part of the American Material Culture Commons, Archaeological Anthropology Commons, Environmental Studies Commons, Other American Studies Commons, Other Arts and Humanities Commons, Other History of Art, Architecture, and Archaeology Commons, and the United States History Commons

Tell us how this article helped you.

This Article is brought to you for free and open access by the Center for Regional Heritage Research at SFA ScholarWorks. It has been accepted for inclusion in Index of Texas Archaeology: Open Access Gray Literature from the Lone Star State by an authorized editor of SFA ScholarWorks. For more information, please contact cdsscholarworks@sfasu.edu. 


\section{Archeological Survey of Wildlife Mitigation Lands, Justiceburg Reservoir, Garza County, Texas}

\section{Creative Commons License}

\section{(c) (1) $\Theta(9$}

This work is licensed under a Creative Commons Attribution-NonCommercial-No Derivative Works 4.0 International License. 


\section{ARCHEOLOGICAL SURVEY OF WILDLIFE MITIGATION LANDS, JUSTICEBURG RESERVOIR, GARZA COUNTY, TEXAS}

By

Douglas K. Boyd

C. Britt Bousman

and

Martha Doty Freeman
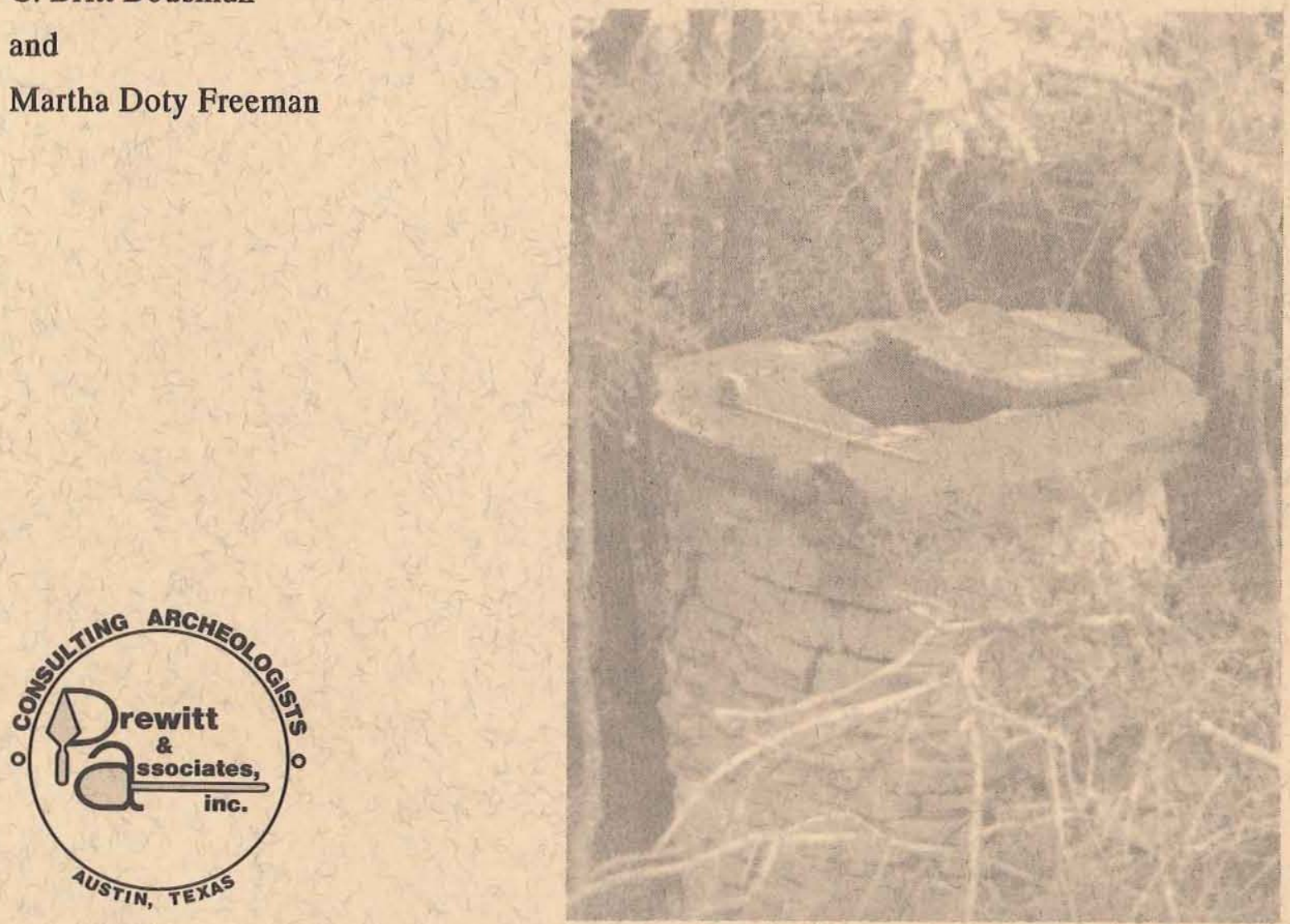

REPORTS OF INVESTIGATIONS, NUMBER 79

TEXAS ANTIQUITIES COMMITTEE PERMIT NO. 939 


\title{
ARCHEOLOGICAL SURVEY OF WILDLIFE MITIGATION LANDS, JUSTICEBURG RESER VOIR, GARZA COUNTY, TEXAS
}

\author{
by \\ Douglas K. Boyd \\ C. Britt Bousman \\ and \\ Martha Doty Freeman
}

Principal Investigator: Elton R. Prewitt

REPORTS OF INVESTIGATIONS, NUMBER 79

\author{
Prewitt and Associates, Inc. \\ Consulting Archeologists \\ Austin, Texas
}

November 1991

TEXAS ANTIQUITIES COMMITTEE PERMIT NO. 939 
Series Technical Editor: Linda Nance Foster 
TABLE OF CONTENTS

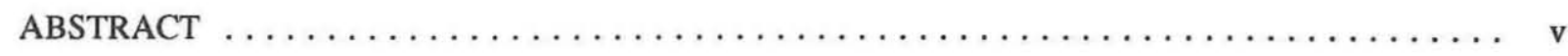

ACKNOWLEDGMENTS $\ldots \ldots \ldots \ldots \ldots \ldots \ldots \ldots \ldots \ldots \ldots \ldots \ldots \ldots \ldots \ldots \ldots \ldots \ldots \ldots \ldots$

CHAPTER 1: INTRODUCTION

Douglas K. Boyd $\ldots \ldots \ldots \ldots \ldots \ldots \ldots \ldots \ldots \ldots \ldots \ldots \ldots \ldots \ldots \ldots \ldots \ldots \ldots \ldots \ldots$

CHAPTER 2: BACKGROUND AND RESEARCH ORIENTATION

Douglas K. Boyd and Martha Doty Freeman $\ldots \ldots \ldots \ldots \ldots \ldots \ldots \ldots$

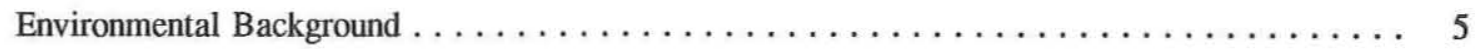

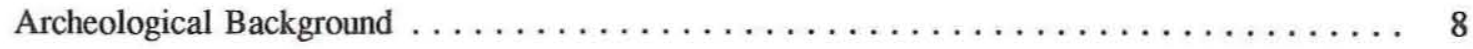

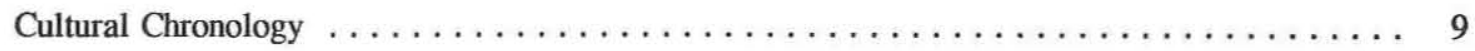

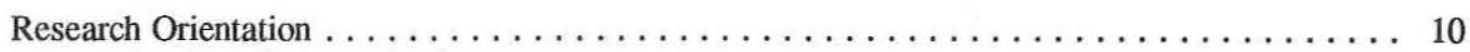

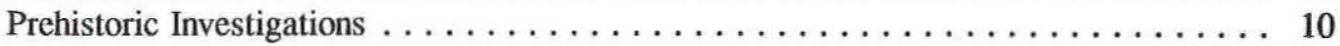

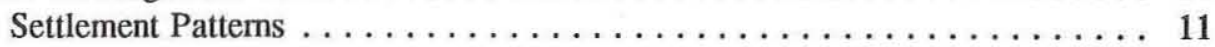

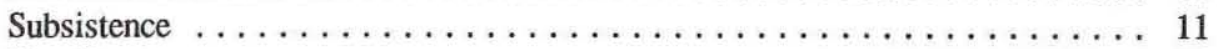

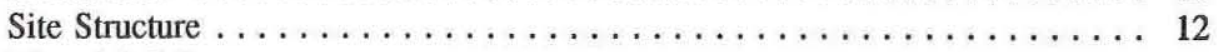

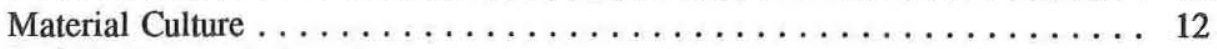

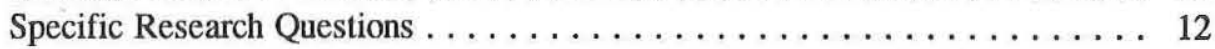

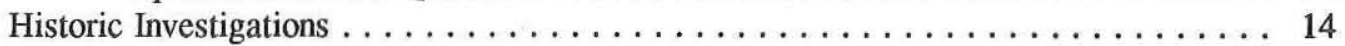

CHAPTER 3: ARCHEOLOGICAL SURVEY

Douglas K. Boyd and Martha Doty Freeman $\ldots \ldots \ldots \ldots \ldots \ldots \ldots$

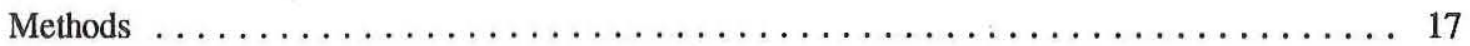

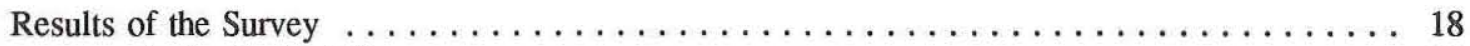

Archeological Sites . . . . . . . 18

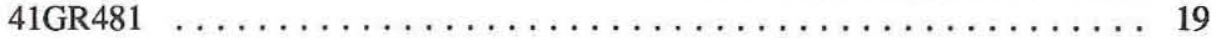

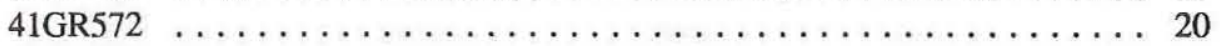

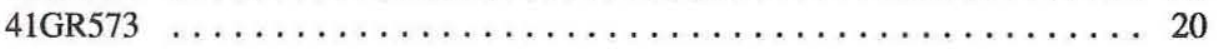

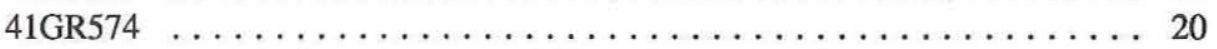

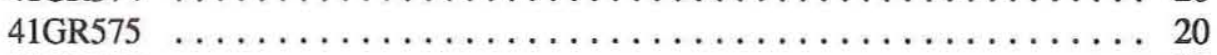

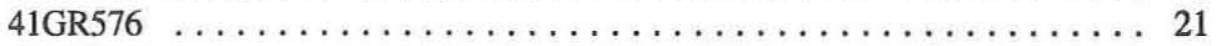

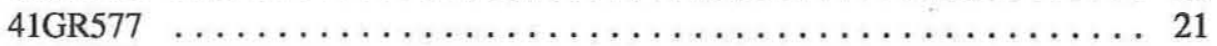

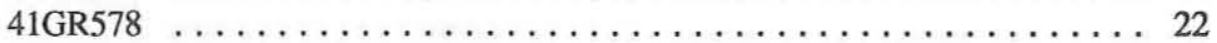

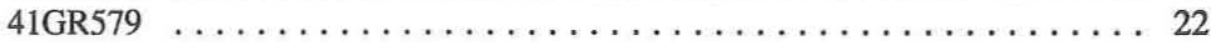

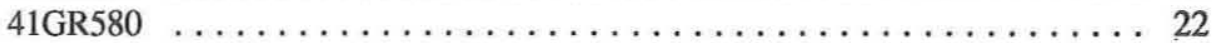

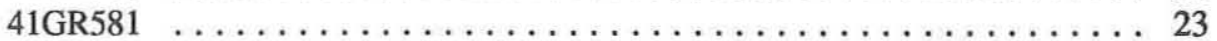

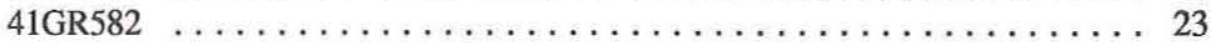

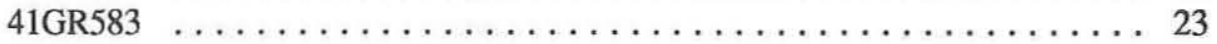

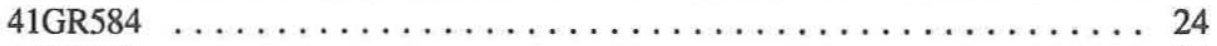

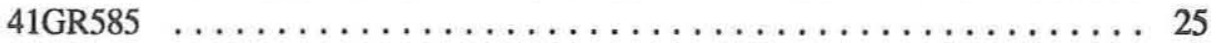

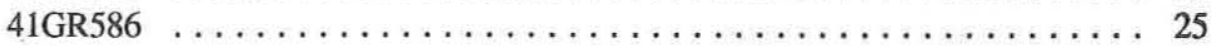

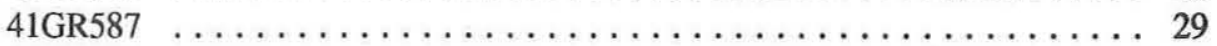

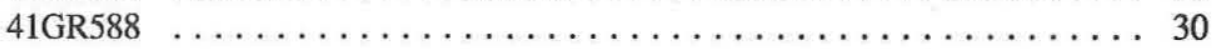

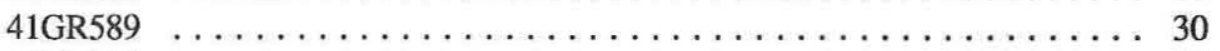

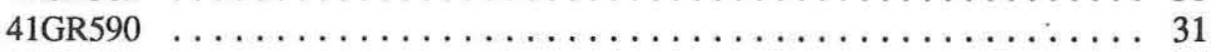

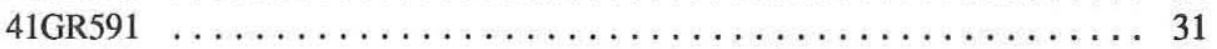

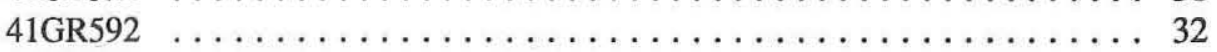

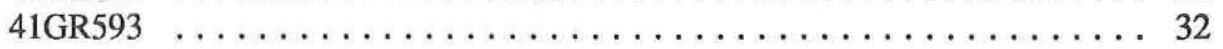




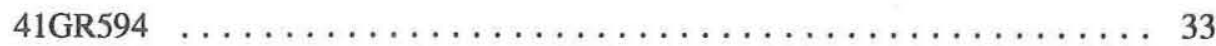

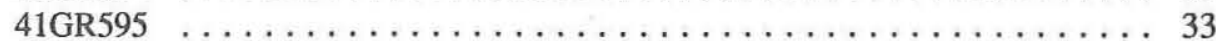

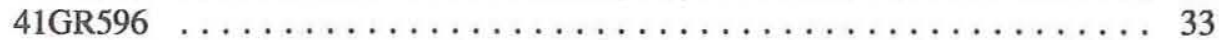

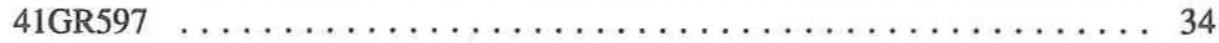

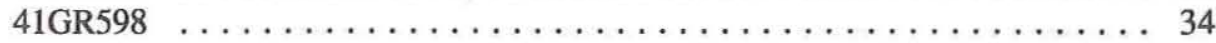

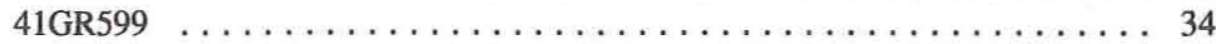

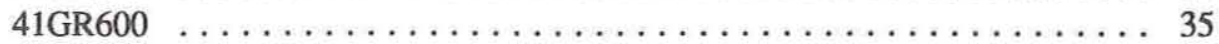

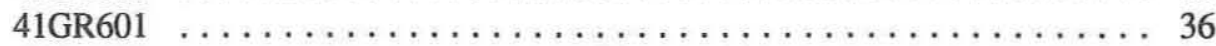

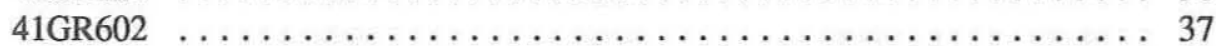

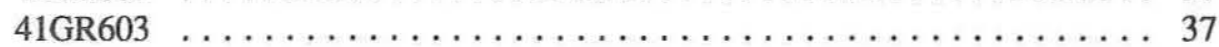

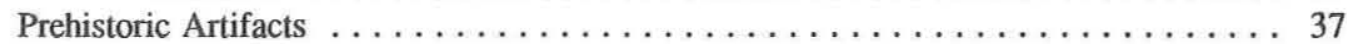

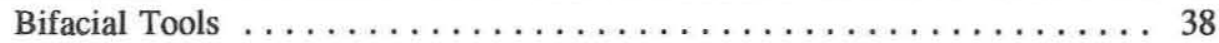

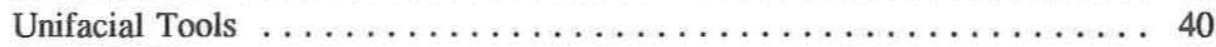

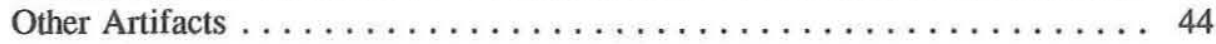

CHAPTER 4: GEOARCHEOLOGICAL INVESTIGATIONS

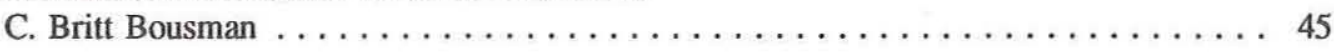

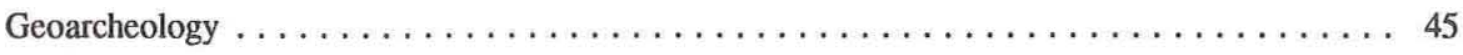

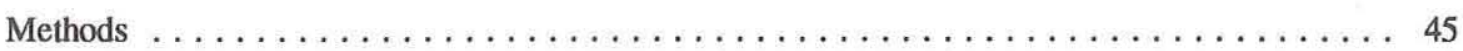

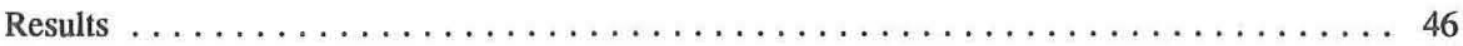

Surface Soils . . . . . . . . . . . . . . . . . . . . . . 46

Upland Sand Sheet and Gravel Deposits $\ldots \ldots \ldots \ldots \ldots \ldots \ldots \ldots \ldots \ldots$

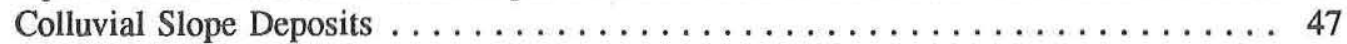

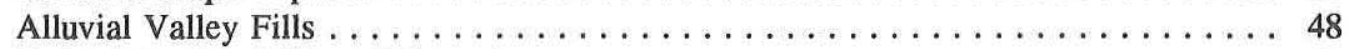

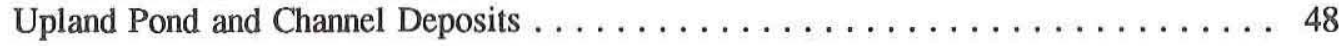

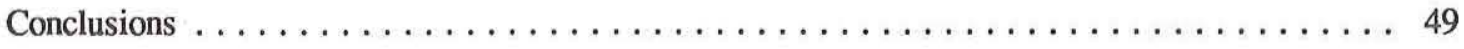

CHAPTER 5: SUMMARY AND CONCLUSIONS

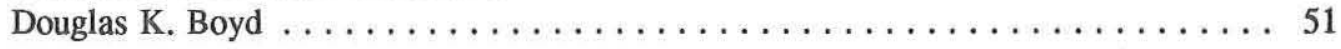

CHAPTER 6: ASSESSMENTS AND RECOMMENDATIONS

Douglas K. Boyd and Martha Doty Freeman $\ldots \ldots \ldots \ldots \ldots \ldots \ldots \ldots \ldots$

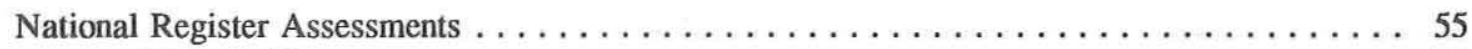

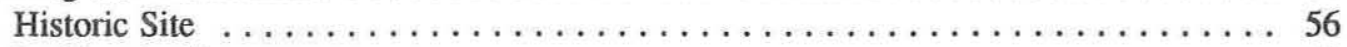

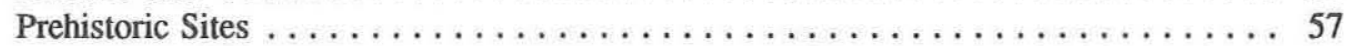

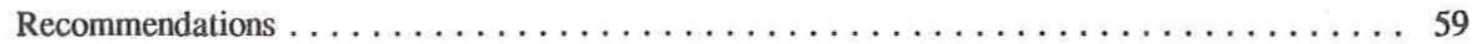

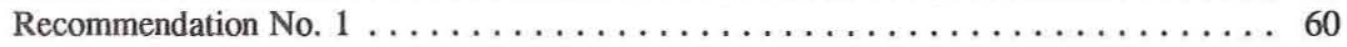

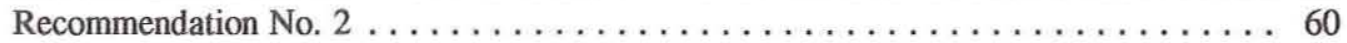

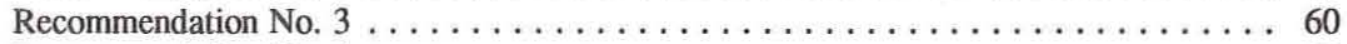

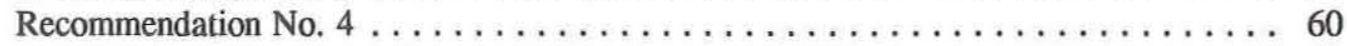

Summary of Recommendations $\ldots \ldots \ldots \ldots \ldots \ldots \ldots \ldots \ldots \ldots \ldots \ldots \ldots \ldots \ldots \ldots$

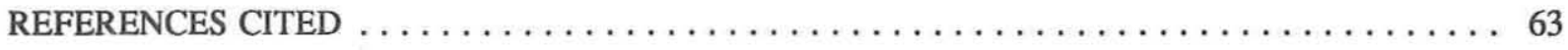

APPENDIX: GEOLOGIC PROFILE DESCRIPTIONS

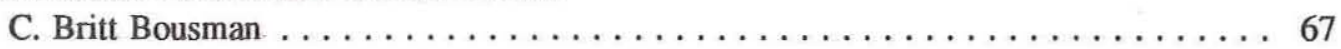




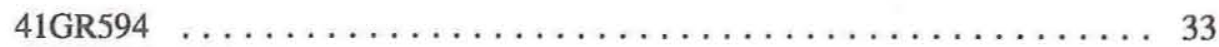

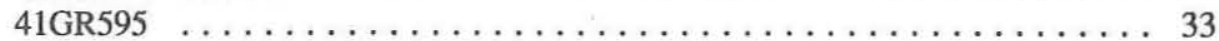

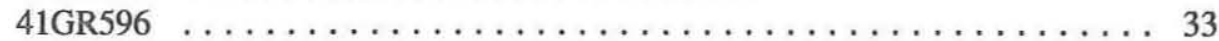

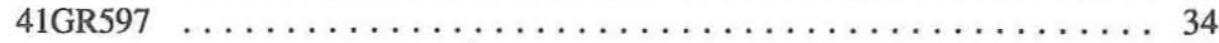

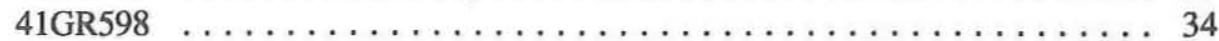

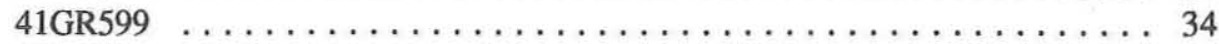

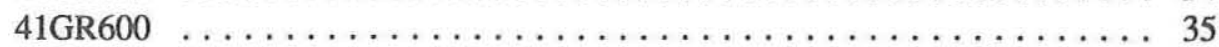

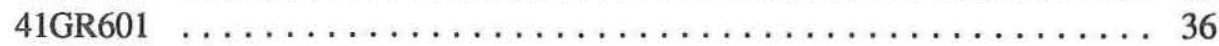

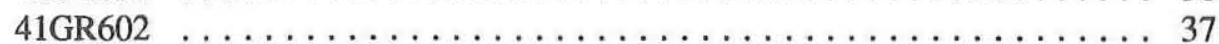

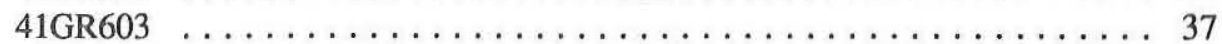

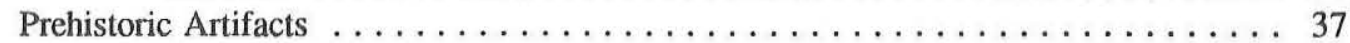

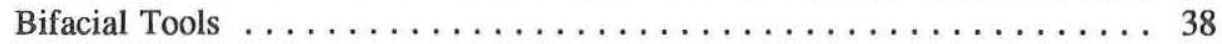

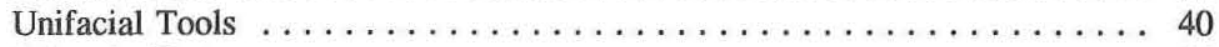

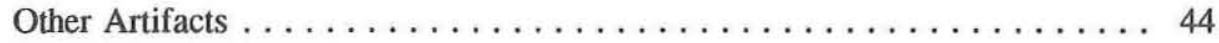

CHAPTER 4: GEOARCHEOLOGICAL INVESTIGATIONS

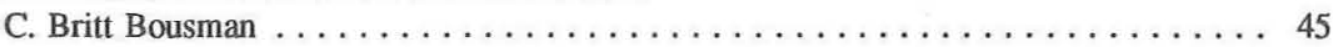

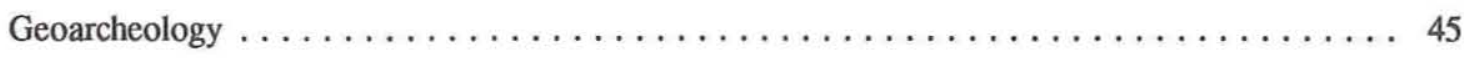

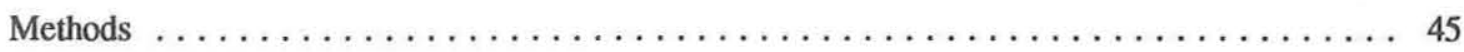

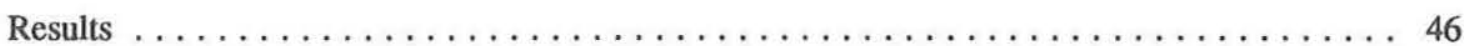

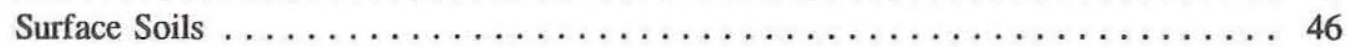

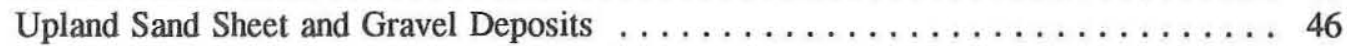

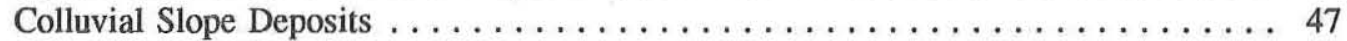

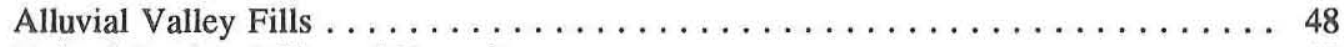

Upland Pond and Channel Deposits $\ldots \ldots \ldots \ldots \ldots \ldots \ldots \ldots \ldots \ldots \ldots \ldots$

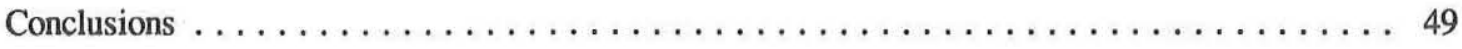

CHAPTER 5: SUMMARY AND CONCLUSIONS

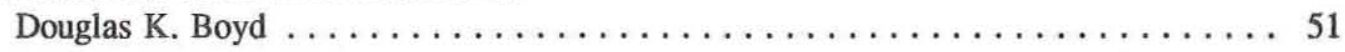

CHAPTER 6: ASSESSMENTS AND RECOMMENDATIONS

Douglas K. Boyd and Martha Doty Freeman $\ldots \ldots \ldots \ldots \ldots \ldots \ldots \ldots$

National Register Assessments . . . . . . . . . . . . . . . . . . . . . . . 55

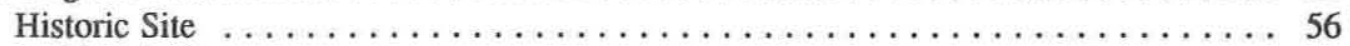

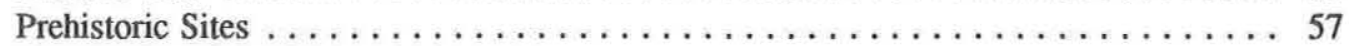

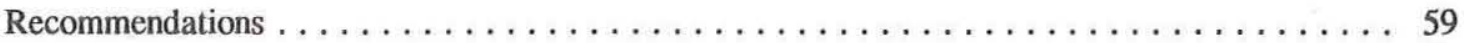

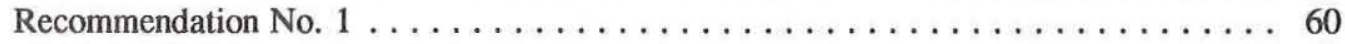

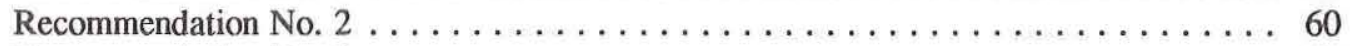

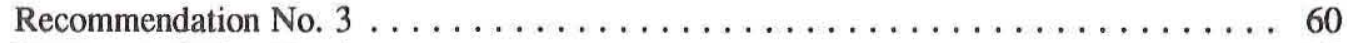

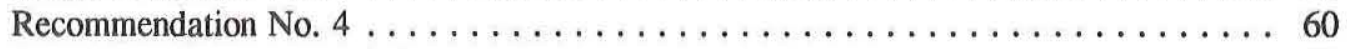

Summary of Recommendations $\ldots \ldots \ldots \ldots \ldots \ldots \ldots \ldots \ldots \ldots \ldots \ldots \ldots \ldots \ldots \ldots$

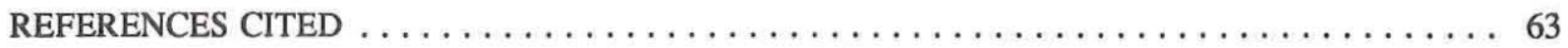

APPENDIX: GEOLOGIC PROFILE DESCRIPTIONS

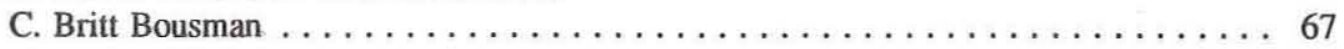




\section{LIST OF FIGURES}

1. Project area map showing intensive and spot-check survey areas $\ldots \ldots \ldots \ldots \ldots \ldots \ldots \ldots$

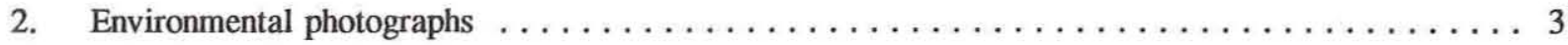

3. Surface topography, generalized landforms, and geologic strata

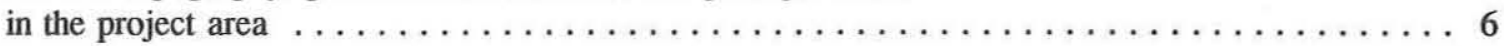

4. Site map of historic Williams homestead complex, 41GR586 $\ldots \ldots \ldots \ldots \ldots \ldots \ldots \ldots 26$

5. Photograph of rock-lined well in small spring, 41GR586 $\ldots \ldots \ldots \ldots \ldots \ldots \ldots \ldots \ldots$

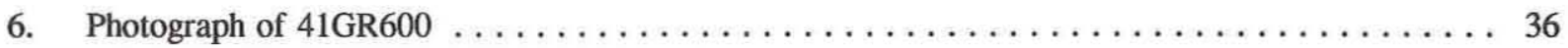

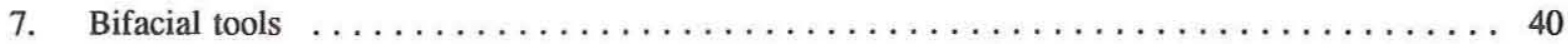

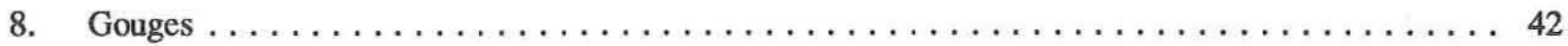

\section{LIST OF TABLES}

1. Specific research questions relating to late Holocene human adaptation

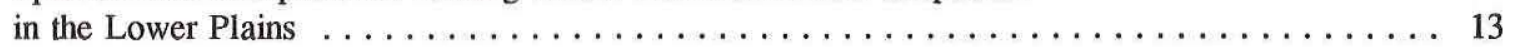

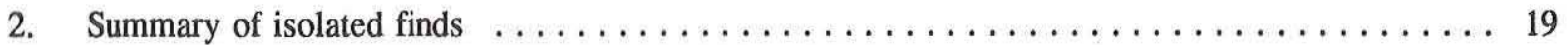

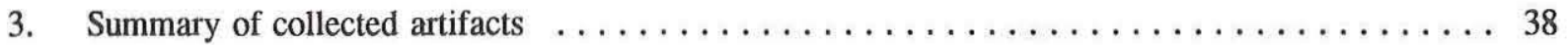

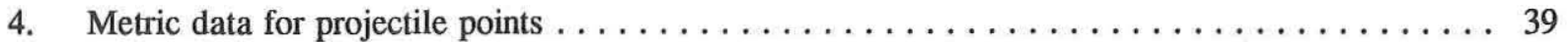

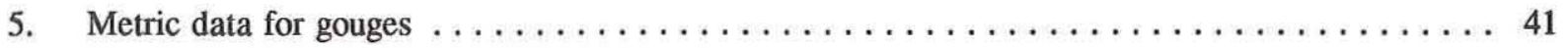

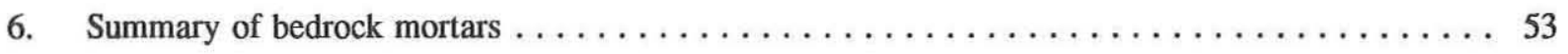

7. Summary of sites and National Register assessments $\ldots \ldots \ldots \ldots \ldots \ldots \ldots \ldots \ldots \ldots \ldots \ldots \ldots \ldots \ldots$ 


\begin{abstract}
In order to fulfill its obligations in conjunction with the proposed Justiceburg Reservoir project, the City of Lubbock, Texas, is considering the purchase of 2,240 acres in Garza County to serve as wildlife mitigation lands. Prior to the City's final decision to acquire the land, an archeological survey was conducted. The ca. 1,000 acres of incised canyonland and upland margin and ca. 215 acres of selected upland rises were intensively surveyed, while the remaining 1,025 acres of upland flat and low-lying areas were spot checked. Subsurface geomorphic investigations (i.e., backhoe trenching) of the uplands were also conducted. The survey resulted in the documentation of 1 historic and 32 prehistoric archeological sites (1 previously recorded). Of these, the historic site is recommended as eligible for listing on the National Register of Historic Places, and eight prehistoric sites are of unknown eligibility. These nine sites will need special management considerations to prevent impacts from wildlife mitigation use of the land.

Historic use of the project area is associated with late nineteenth/early twentieth-century cattle ranching, while all of the prehistoric occupations that can be temporally defined are late Archaic or Late Prehistoric. Most of the cultural activity is clustered around three major freshwater spring complexes. There appears to have been intensive use of these areas during the late Holocene but only ephemeral prehistoric use of the uplands more than $0.5 \mathrm{~km}$ away from the springs and stream channels.

Geomorphic evidence indicates that extensive root-plow disturbance occurred in many upland areas, but well-preserved archeological deposits are present in portions of the eroded upland margin. Three unique upland depositional environments (playas with associated dunes, channels, and pond deposits) have the potential for preserving buried cultural remains of considerable antiquity as well as providing paleo-environmental data which is lacking at this time.
\end{abstract}




\section{ACKNOWLEDGMENTS}

The City of Lubbock, Texas, provided the funding for this investigation, arranged land access, and provided a backhoe and operators for the geomorphic study. Mr. Dan Hawkins, Director of Water Utilities, and Mr. Mike Gilliland, Engineer Assistant with Water Utilities, deserve special thanks for their cooperation and assistance. Also, thanks go to the landowners at the time the survey was conducted, Mr. and Mrs. John Reed, who allowed access to their property, and to Mrs. Mary Ellen Headstream of Abilene, Texas. Mrs. Headstream is a descendant of an early settler in the area and, with her brother William Wayne Williams, provided essential information to the Project Historian.

The archeological field crew did a superb job under sometimes hot and miserable conditions. My personal thanks to Joe Sanchez (Assistant Project Archeologist), Jeff McCulloch and Abby Treece (Archeological Technicians), and Margaret Howard (PAI Staff Archeologist) for their hard work. The geomorphic field investigation was conducted by Elton R. Prewitt (Principal Investigator) and C. Britt Bousman (Project Geomorphologist), and historic field and archival research was conducted by Martha Doty Freeman (Project Historian). The cooperation and input from these people made my job much easier and is greatly appreciated. Thanks also go to the rest of the PAI staff, who did their usual professional job. Drafting of the figures was done by Karen Gardner, artifact illustrations are by Ellen Atha, editing was done by Linda Foster and Elton R. Prewitt, and Foster typed the report.

Douglas K. Boyd

Project Archeologist 



\section{INTRODUCTION}

by Douglas K. Boyd

Justiceburg Reservoir (to be known as Lake Alan Henry on completion), proposed by the City of Lubbock, Texas, will inundate ca. 2,800 acres of canyonlands and will alter the environmental conditions of many more acres surrounding the lake. Section 404 of the Clean Water Act requires the City to obtain a permit, issued through the U.S. Army Corps of Engineers, to construct the reservoir. Under the Section 404 permit, the City must provide for mitigation of the wildlife habitats that will be destroyed or altered by the project. In accordance with these provisions, the City proposes to acquire approximately 2,240 acres of environmentally similar property in Garza County to serve as wildlife mitigation lands. The Section 404 permit and the Memorandum of Agreement (Stipulations IB-ID) require that the cultural resources on this property be identified and assessed. The City elected to conduct the archeological survey of this tract prior to its decision to purchase the land. The archeological investigation of the wildlife mitigation lands was conducted, at the request of the City, by Prewitt and Associates, Inc. in August and September of 1990. Subsequent to the survey, it was determined that the cultural resources would require special management consideration but would not significantly alter the wildlife mitigation plans.

The 2,240-acre tract of land includes ca. 1,240 acres of uplands and 1,000 acres of upland margin and incised canyons (Figs. 1 and 2). In consultation with the Corps of Engineers and the State Historic Preservation Officer, it was decided that all of the canyonlands should be covered by a $100 \%$ pedestrian survey, but a comparable level of effort was not warranted in the uplands. Previous intensive surveys of upland tracts in the Justiceburg Reservoir project area have shown that upland prehistoric sites in the region are very predictable, being located on high rises or near playa depressions. Since there are no playa depressions in the wildlife mitigation tract, the main potential for upland prehistoric sites is limited to the high rises. It was agreed that the upland areas could most effectively be covered by spot checks and intensive survey of selected high rises and through limited subsurface geoarcheological testing (i.e., backhoe trenching) of selected locations. The investigations reported herein include a $100 \%$ pedestrian archeological survey of ca. 1,215 acres (includes approximately 215 acres of uplands), spot-check survey of the remaining 1,025 acres of uplands, and a geoarcheological study that included 14 backhoe trenches in the uplands as well as a reconnaissance of the valley bottom.

Chapter 2 presents environmental and archeological backgrounds, a synopsis of cultural chronology as currently understood for the region, and the research orientation that guided this project. Chapter 3 presents the methods and results of the archeological survey, including descriptions of the sites recorded and the cultural materials recovered. Chapter 4 describes the methods and results of the geoarcheological investigations. Chapter 5 presents a summary and conclusions of the work conducted, and Chapter 6 provides site assessments and recommendations. Geologic profile descriptions are provided in the appendix. 


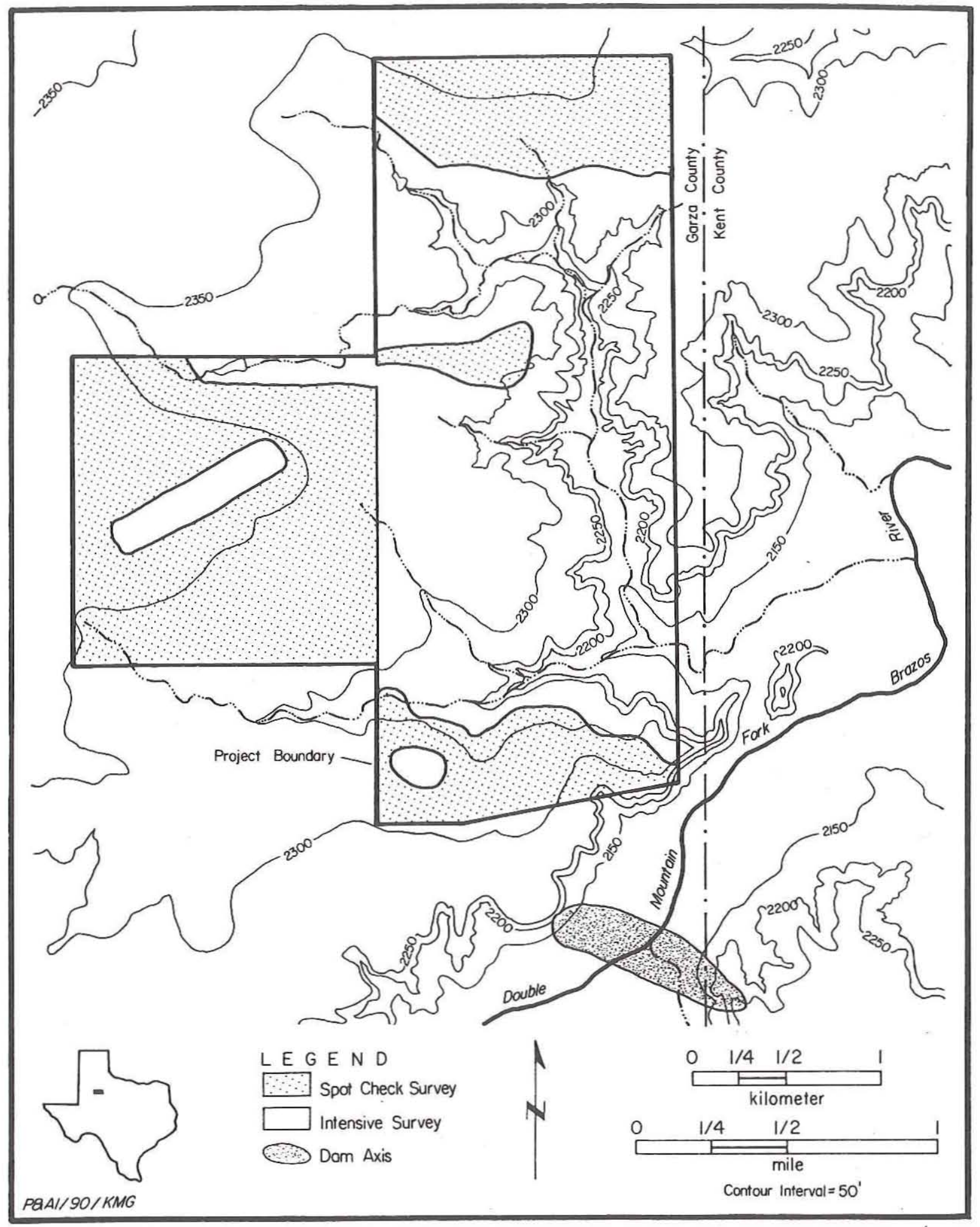

Figure 1. Project area map showing intensive and spot-check survey areas. 


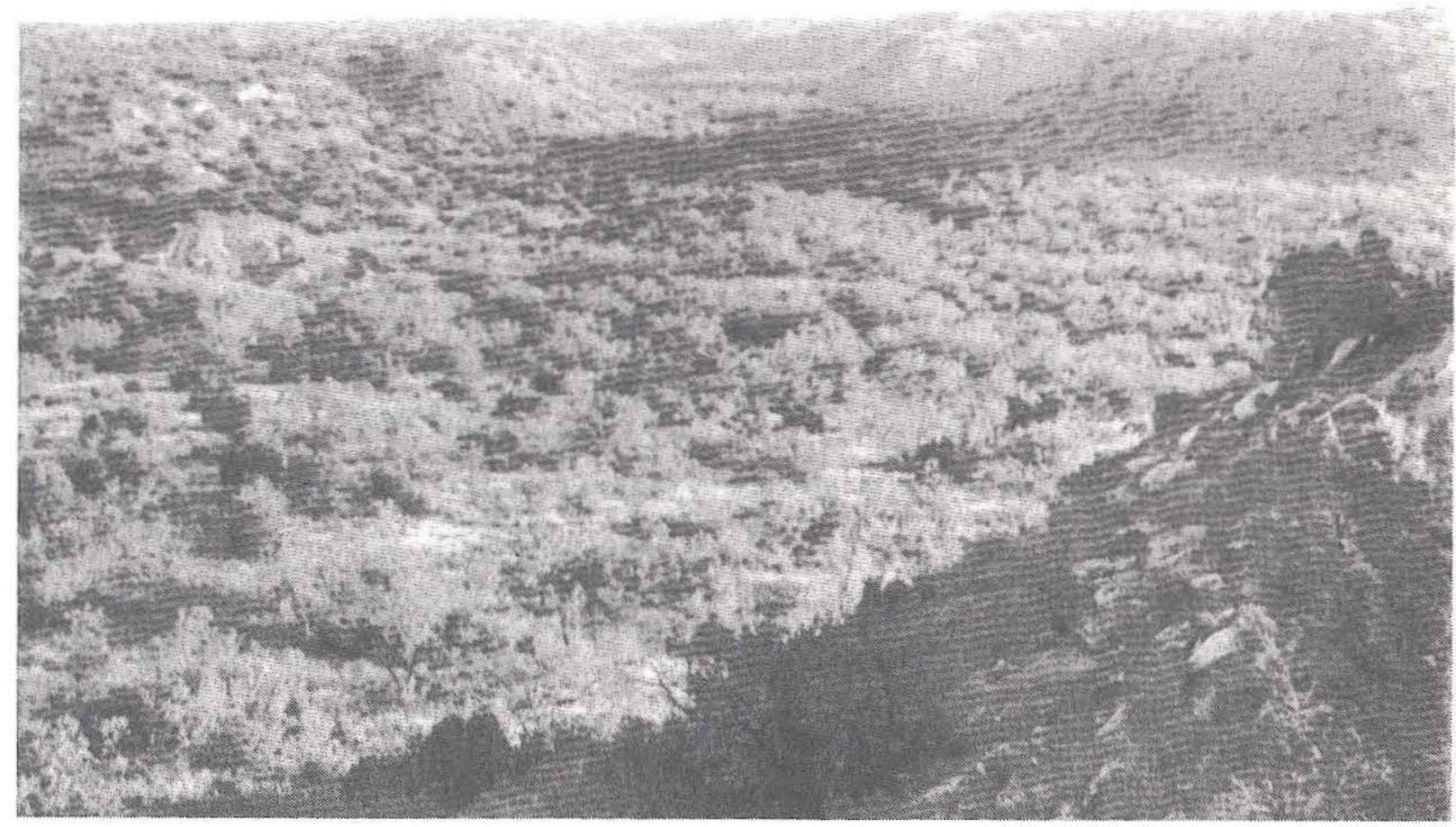

a

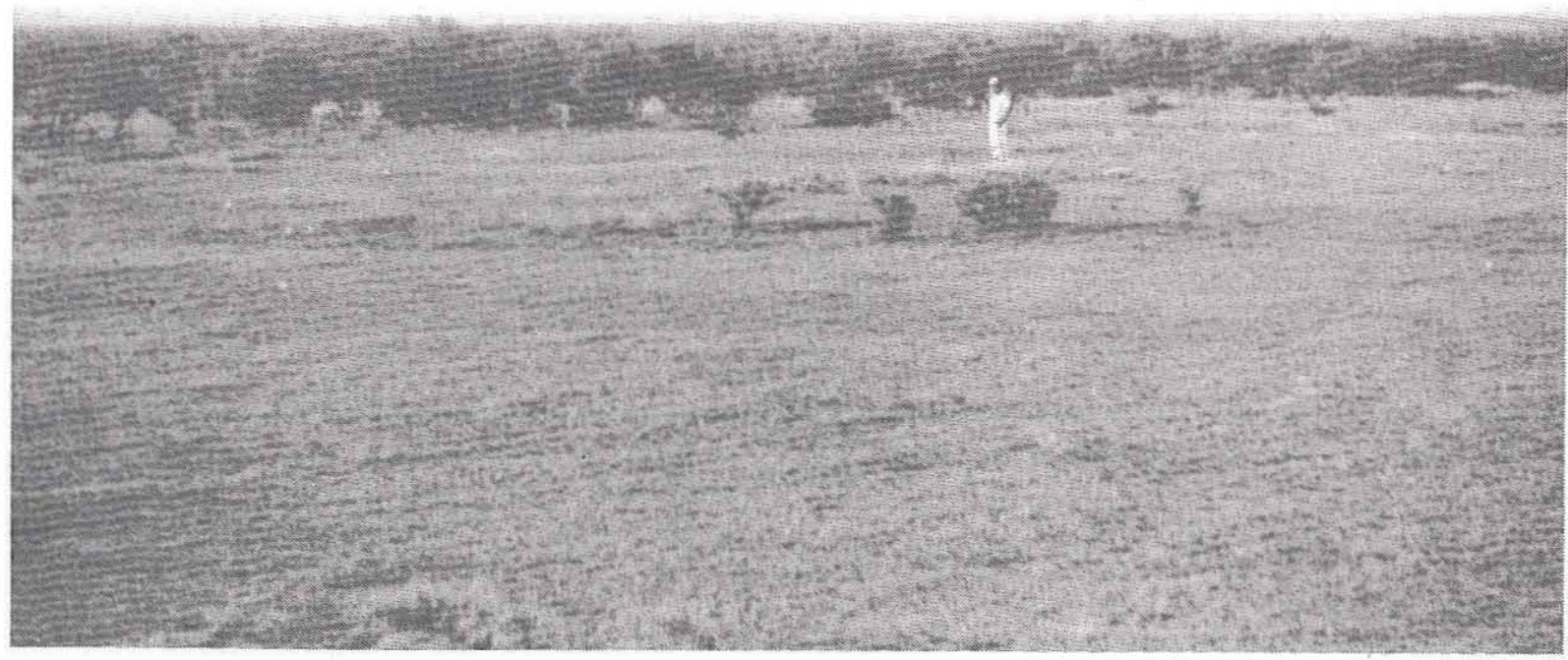

b

Figure 2. Environmental photographs. (a) General view of canyonland topography, looking upstream (north) in main drainage valley; (b) general view of upland topography, view southeast at site 41GR593; note upland rise is devoid of large vegetation, while low-lying upland area in background has dense vegetation growth. 


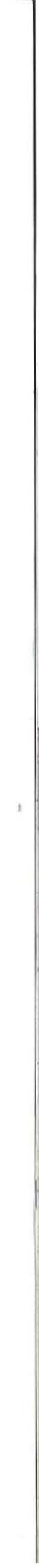




\section{BACKGROUND AND RESEARCH ORIENTATION}

by Douglas K. Boyd and Martha Doty Freeman

The following environmental and archeological background information is a brief synopsis of information compiled during other phases of work at Justiceburg Reservoir. Except for specifics relating mainly to the wildlife mitigation area, more-detailed background information is available elsewhere (Boyd et al. 1989; Boyd, Abbott et al. 1990; Freeman and Boyd 1990).

\section{ENVIRONMENTAL BACKGROUND}

The wildlife mitigation tract is located in southeastern Garza County, immediately north of the proposed Justiceburg damsite (see Fig. 1). The eastern edge of the project area is less than $200 \mathrm{~m}$ (656 ft) from and runs parallel to the Garza-Kent county line. The project area includes roughly three and one-half sections (half of Section 70 and all of Sections 71,72 , and 78) and is bisected by an unnamed ephemeral drainage and its tributaries. The main drainage heads in the uplands at the northern end of the project area and flows southward. In the southern end of the project area, an east-flowing tributary joins with the main drainage. At this point, the main drainage bends eastward and flows ca. $1.5 \mathrm{~km}$ (0.9 mile) east-northeast to its confluence with the Double Mountain Fork of the Brazos River. Three prominent freshwater springs (or spring complexes) exist in the survey area, and the prehistoric and historic occupations/activities are clustered around these locations.

The project area surface geology is relatively simple, consisting of only four components. In reverse stratigraphic order from top to bottom of the valley profile, these are the Quaternary-age (late Pleistocene and Holocene) Lingos formation on the uplands, the Triassic-age Dockum Group and the Permian-age Quartermaster Formation which form the valley walls, and late Holocene channel fill in the valley bottom (Fig. 3). The Lingos formation consists of relatively recent gravels and sands deposited as outwash from the retreating Caprock Escarpment and a thin veneer of eolian sands, all of which were deposited within the last ca. 100,000 to 150,000 years. The Lingos formation has only recently been proposed by Caran and Baumgardner (1988), and it is still considered to be an informal geological unit. The Lingos gravels consist mainly of materials derived from the Ogallala Formation but also include a small amount of Cretaceous fossils and cherts. The Ogallala materials are dominantly coarse-grained quartzites (or metaquartzites) and Potter chert (a silicified siltstone) but also include various types and qualities of chert, silicified wood, and occasional pieces of poor-quality silicified or opalized caliche (Holliday and Welty 1981:208-209).

The Lingos formation lies unconformably on the hard Triassic Dockum Group sandstones (Barnes 1967) which form the canyon rim. The Dockum Group sediments include various alternating layers of sandstones, clays and shales, and conglomerates. The Dockum Group comprises the major bedrock exposure throughout the Justiceburg Reservoir area, but these formations thin eastward and disappear near the proposed damsite and the Garza-Kent county line. In the wildlife mitigation area, the Dockum Group is 


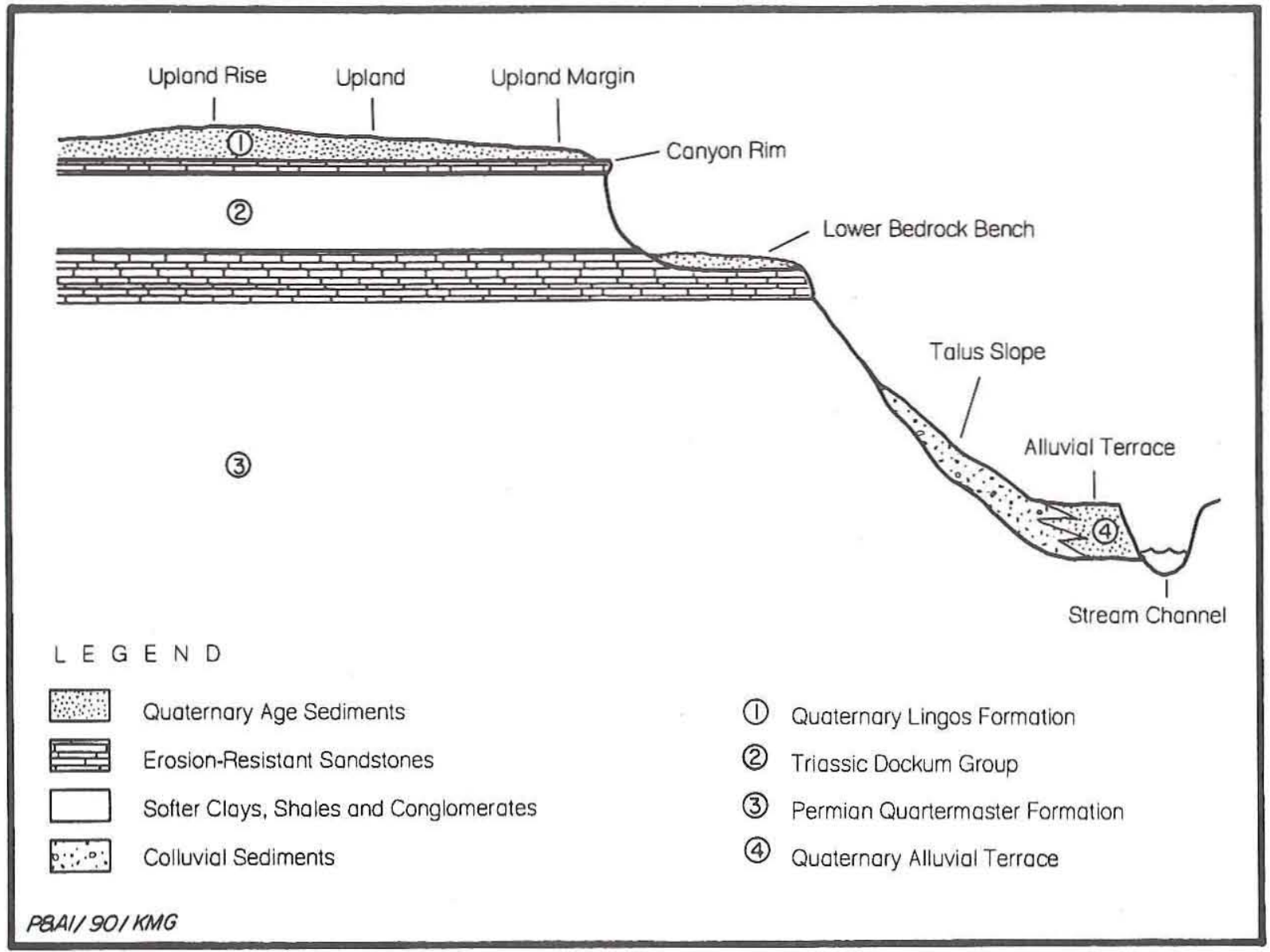

Figure 3. Surface topography, generalized landforms, and geologic strata in the project area.

very thin and the valley walls are dominantly Permian exposures. The uppermost Permian layer, the Quartermaster Formation, is a very thick deposit of interbedded shales, sandstones, gypsum, and dolomite (Barnes 1967), but only the uppermost portion of the Quartermaster, limited to shales and sandstones, is exposed in the project area. Immediately downstream from the project area and in the vicinity of the proposed damsite, Permian gypsum layers are exposed. The prominent red-colored mudstones of the Permian Quartermaster (and other formations) have given the name "redbeds" to the eroded Lower Plains region.

The topography and landforms in the wildlife mitigation area (see Fig. 2) are similar to those in the main reservoir area (see Boyd et al. 1989:Figure 7). Total relief is as much as $32-37 \mathrm{~m}(100-120 \mathrm{ft})$ from the canyon rim to the stream channel. The valley walls generally are very steep, with a ca. 30-m (98-ft) drop in less than 50 lateral meters (164 ft), but extensive lower bedrock benches, as wide as $250 \mathrm{~m}(820 \mathrm{ft})$, sometimes separate the canyon rim from the stream channel. In contrast, the upland flat is gently sloping with as little as a 6-m $(20-\mathrm{ft})$ vertical drop in $500 \mathrm{~m}(1,640 \mathrm{ft})$ horizontally.

The valley bottom in the wildlife mitigation area is composed of Quaternary-age alluvial and alluvial/ colluvial sediments. Based on the initial inspection of the valley sediments and the intensive geomorphological work in the main reservoir area, it is likely that the alluvial sediments in the wildlife mitigation tract are very recent deposits, i.e., late Holocene. In the project area, the stream valley is wide at its lower end but narrows upstream. At its widest, the alluvial floodplain is ca. $500 \mathrm{~m}(1,640 \mathrm{ft})$ across, but in the narrow portion of the canyon the alluvial terraces are less than $50 \mathrm{~m}(164 \mathrm{ft})$ wide and the stream channel is often bedrock. The upper ends of 
all of the drainages (below the canyon rim) generally have little or no alluvial or alluvial/colluvial terrace development, and the stream channel is bedrock.

The upstream section of the valley is characterized by colluvial sediments spilling out into the valley bottom. Farther downstream, small colluvial fans occur at the base of the steep valley walls and extend short distances into the floodplain. These steeply sloping fan deposits interfinger with alluvial deposits in the floodplain, and buried gravel stringers mark depositional surfaces within the fans. These gravel stringers terminate approximately where the colluvial deposits interfinger with the alluvial floodplain deposits. In some areas, large to small sandstone blocks have dislodged from the valley wall, and these are also contained within the colluvial and alluvial sediments.

The prehistoric inhabitants in the Southern Plains had access to a wide variety of lithic resources. Banks (1990) provides an exhaustive treatment of lithic sources of that area, and the following is a brief synopsis of the lithic sources used by prehistoric peoples in the Texas Lower Plains. In the Justiceburg vicinity, there is an abundant source of low-tomoderate-quality lithic materials in the form of gravel outcrops. The Quaternary Lingos formation gravels are found in abundant but sporadic outcrops throughout the area and constitute the main source of lithic raw materials. Coarse-, medium-, and finegrained quartzites are the dominant materials in the Lingos gravels and were utilized for chipped stone tools (mainly gouges and scrapers but occasionally for projectile points) and ground stone manos. In addition, these materials were utilized extensively in burned rock features, i.e., hearths and roasting pits, or as boiling stones. Fire-cracked rocks are the most abundant material found on some sites. The medium-to-coarse-grained quartzites (includes orthoquartzites and metaquartzites) are derived originally from the basal gravels of the Ogallala Formation and hence are generally called Ogallala quartzites. The finer-grained material is brown to gray and is also derived originally from the Ogallala Formation. This material is locally called Potter chert, a name that is technically incorrect since it is actually a silicified siltstone (Holliday and Welty 1981:208-209), but it does distinguish it from the other Ogallala quartzites. Potter chert, named for the now-obsolete Potter Formation, is by far the most abundant material in the Lingos gravels around Justiceburg.
The Lingos gravels also contain relatively small quantities of cherts, silicified wood, and silicified caliche, although these are usually much smaller than the quartzite and Potter chert nodules. All of these materials, however, are occasionally of usable size and chippable quality. The cherts include a wide variety of materials which vary considerably in color and texture. Some of the better quality brown to gray cherts in the Lingos gravels undoubtedly were derived originally from Cretaceous formations. These local Cretaceous cherts, however, are not comparable in quality to the Cretaceous cherts from Central Texas.

The Triassic Dockum Group exposures provided abundant sandstone which was used for artifacts such as metates and features such as hearths and bedrock mortars, and to a lesser extent, the gravels contained in the Triassic conglomerates provided a source of chipped stone materials. The Triassic conglomerate contains generally small (most are pebble sized) gravels which are found redeposited in the Lingos formation but also as intact conglomerate exposures which erode into isolated gravel outcrops.

Nonlocal materials that were used prehistorically in the project vicinity include Edwards chert, Alibates agate, Tecovas jasper, obsidian, and other unidentified materials. The Central Texas cherts, generally of Cretaceous origin and collectively called Edwards chert (Banks 1990:59-61), include a variety of white, tan, brown, gray, and black, very fine grained, highquality materials. The closest Cretaceous outcrops that are known to contain substantial chert outcrops are located in the Callahan Divide area ca. 80 to $90 \mathrm{~km}$ (50 miles) southeast of Garza County.

Alibates agate, a very high quality multicolored (red and white banded is the most distinctive) raw material, is derived from the dolomite beds in the Permian Quartermaster Formation. The only known outcrop of any significance, however, is found along the Canadian River in the northern Texas Panhandle, ca. $275 \mathrm{~km}$ (170 miles) north of Garza County. Alibates agate is found as secondary deposits in the Canadian River basin stream gravels in the eastern Texas Panhandle and western Oklahoma, but no other in situ Quartermaster Formation source areas are known.

The Triassic Dockum Group also includes very localized outcrops of Tecovas jasper, a medium-tohigh-quality chert that is characterized by a wide range of colors and abundant quartz inclusions (called vugs). Tecovas jasper, however, is not known to be found in the immediate vicinity of the project area. 
The closest documented outcrops are those in the Quitaque area ca. $130 \mathrm{~km}$ (80 miles) north of Justiceburg, but other outcrops are reported (but not substantiated) elsewhere in the Lower Plains and even as close as $20 \mathrm{~km}$ (12 miles) away in northern Garza County.

Obsidian is occasionally found in the project vicinity, but it usually comprises only a small percentage of any one site's lithic assemblage. It was brought into the Southern Plains from quite some distance, and recent source material studies (i.e., trace element analyses) indicate that the dominant source areas are in northern New Mexico and less frequently in Idaho. Obsidian appears to be uncommon until Late Prehistoric times, when its use increased considerably.

The project area is characterized by a mild climate with extreme periods of heat, cold, rainfall, and drought. Average monthly temperatures range from $14.4{ }^{\circ} \mathrm{C}\left(28^{\circ} \mathrm{F}\right)$ to $35.5^{\circ} \mathrm{C}\left(96^{\circ} \mathrm{F}\right)$ with a growing season of 214 days. Yearly rainfall occurs primarily in the spring and summer months and averages $49 \mathrm{~cm}$ (19.3 inches) (Pass 1981:122).

The project area is located in the Mesquite Plains district of the Kansan biotic province (Blair 1950) and contains a wide range of plant and animal resources that could have been exploited by the prehistoric inhabitants. Recent land modifications, such as vegetation clearing and cattle ranching, have altered the plant and animal communities to a large extent. For example, the western ca. one-third of the wildlife mitigation tract (Section 78) consists of uplands that have been entirely root plowed, while the remainder of the project area does not appear to have been cleared of vegetation. This provides a sharp contrast since the western section has been invaded by a forest of cholla and prickly pear except on the high rises where the soils are much thinner. Unmodified uplands have well-established grass with considerably less shrub and cactus vegetation, most of which is confined to the low-lying areas. Upland rises have shallow sediments that support less vegetation growth (see Fig. 2b). In addition, a review of old air photos (from 1941 and 1968) suggests that the shrub and cactus vegetation has increased dramatically in recent years, probably as a result of overgrazing.

\section{ARCHEOLOGICAL BACKGROUND}

The history of archeological investigations in the Justiceburg Reservoir area and the development of the region's cultural sequence are long and complex stories. A comprehensive archeological background is presented in Boyd et al. (1989:23-59), and only a brief synopsis is presented here.

Archeological interest in the Justiceburg area began in the 1950s as members of the South Plains Archeological Society began documenting and investigating sites in Garza County. Professional archeological investigations, however, did not begin until Justiceburg Reservoir was in the early planning stages in the 1970s. The initial archeological work was a survey of the proposed reservoir area funded by the South Plains Association of Governments (SPAG). This work, conducted in 1974-1975, produced an inventory of archeological sites and resulted in a series of reports (Campbell 1975, 1977; Campbell and Judd 1977a, 1977b; Judd 1977) but made very minimal recommendations for treatment of the resources. A second archeological investigation (Alexander 1982) documented selected sites in order to evaluate the results of the SPAG survey and their recommendations. Alexander (1982:3-4) concluded that the cultural resources were not adequately recorded and that their true significance had been underestimated. A complete resurvey of the proposed Justiceburg Reservoir area and a reevaluation of its cultural resources was recommended.

The proposed Justiceburg Reservoir area, including the construction zones, the flood pool, and a shoreline easement around the reservoir (ca. 8,600 acres), was intensively resurveyed by Prewitt and Associates, Inc. in 1987. This Phase I investigation included a detailed regional historic overview, subsurface geoarcheological testing, and an intensive pedestrian survey (Boyd et al. 1989). The survey resulted in the documentation of 375 sites, and site significance was reevaluated. Sites were assessed relative to very specific prehistoric and historic research problems identified for the Lower Plains region of Texas. Most of the sites $(n=238)$ were considered to be potentially eligible for listing on the National Register of Historic Places because of their integrity and potential to provide data relevant for addressing regional research problems. It was recommended that a sample of the various site types be tested to determine their National Register significance.

Phase II testing of a sample of the cultural resources was conducted by Prewitt and Associates, Inc. in 1988. This study (Boyd, Abbott et al. 1990; Freeman and Boyd 1990) included various levels of 
archeological testing and documentation at 67 sites, an intensive geoarcheological investigation, and the development of two regional historic contexts and a prehistoric research design to provide the framework for National Register assessments of the historic and prehistoric resources. Based on these contextual models, 17 prehistoric and rock art sites and 7 historic sites were recommended as eligible for listing on the National Register of Historic Places.

The next step is the implementation of a comprehensive Phase III archeological investigation that will be initiated in the near future. The selection of a tract of wildlife mitigation land and the inventory of its cultural resources is an integral part of the process of planning and constructing a reservoir. This cultural resources study of the Justiceburg wildlife mitigation lands benefits greatly from the data compiled by the previous intensive archeological investigations of the reservoir area. These recent investigations have provided a much greater understanding of the cultural chronology of the region, the complex interactions between man and his environment, and the archeological record of the Lower Plains region. In addition, the comprehensive research orientations developed during the Phase II study serve as a framework for evaluating the significance of resources documented by the archeological survey of the wildife mitigation lands.

\section{CULTURAL CHRONOLOGY}

The Lower Plains of Texas were inhabited by man for at least the last ca. 12,000 years, but the recent archeological studies at Justiceburg suggest that the region's archeological record is extremely biased. Severe erosion of the landscape over thousands of years has removed a considerable amount of the late Pleistocene and early/middle Holocene sediments and landforms. The result is an archeological record dominated by late Holocene (i.e., late Archaic, Late Prehistoric, and Historic) sites. This phenomenon has been noted in the past but is only now beginning to be understood. A growing body of paleoenvironmental, archeological, and geomorphic evidence for the region strongly suggests that a long period of severe aridity during the mid Holocene, called the Altithermal period, is responsible for the accelerated erosion and removal of earlier sediments. While the evidence is far from conclusive, this phenomenon is evident in the geomorphic record at Justiceburg Reservoir.
The Paleoindian and early/middle Archaic periods (ca. 11,000-4500 B.P.) are not well represented in the Lower Plains. Diagnostic projectile points dating to these periods are sometimes found, but intact cultural deposits of this age are rare. In the Justiceburg Reservoir area, no intact components firmly dated to these time periods have been found, and only a few possible candidates exist. In the canyonland environment in and around the reservoir, it appears that erosion and retreat of the canyon rim and valley walls occurs very rapidly, and it is doubtful if evidence of any early human occupations along the upland margin would be preserved. Likewise, the Double Mountain Fork of the Brazos River and its major tributaries are dynamic fluvial systems that apparently have stripped away all of the early sediments except for a few isolated remnants. Thus, it appears that the potential for Paleoindian and early/ middle Archaic occupations is limited to the uplands, and such occupations most likely would be found near large playa lakes or on high rises within a few hundred meters of the canyon rim.

The prehistoric archeological record at Justiceburg Reservoir dates almost entirely to the late Archaic (ca. 4500-2000 B.P.) and Late Prehistoric (ca. 2000 B.P. to European contact) periods, and sites from both periods are preserved along the eroding upland margin, on lower bedrock benches, and in the stream valley alluvial terraces. No late Archaic cultural phases or complexes have been adequately defined for the region, but late Archaic sites are very common. The Summers Complex proposed for southwestern Oklahoma (Leonhardy 1966) may be a valid cultural unit in the Texas Lower Plains, but this remains to be demonstrated.

The region's Late Prehistoric period is only somewhat better understood. Ceramics and arrow points appear early in the first millenium A.D., and the Texas Panhandle-Plains sites show influence from two different areas. The Late Prehistoric I period (ca. $2000-1000$ B.P.) in the northern PanhandlePlains is characterized by occupations with demonstrated Woodland influence (e.g., cordmarked pottery), while contemporaneous occupations in the southern Panhandle-Plains show strong cultural ties with the Southwest. The Palo Duro Complex defined for the southern Lower Plains (Willey and Hughes 1978) is characterized by Mogollon-style pithouse architecture and imported Jornado Brownware pottery. Several sites in the Justiceburg Reservoir area have been recognized as belonging to the Palo Duro 
Complex.

The Late Prehistoric II (ca. 1000 B.P. to European contact) and Protohistoric/Historic aboriginal (European contact to ca. 1875) periods include the Garza Complex and historic Plains Indian occupations. The Garza Complex, defined in the vicinity of Justiceburg (Runkles 1964), dates to ca. A.D. 14001700 and is characterized as a bison-hunting nomadic lifestyle that may be associated with an influx of bison back into the Southern Plains after a period of relative scarcity. Only a few sites associated with the Garza Complex have been archeologically investigated, however, and the complex remains ill defined. Many sites in the Justiceburg Reservoir area date to this time period, and it is likely that at least some of them belong to the Garza Complex, although no Garza or Lott arrow points characteristic of the complex have been found. Campsites containing Protohistoric or Historic aboriginal materials have not been identified in the Justiceburg Reservoir area, although many sites appear to date to the critical period of European contact. The use of the area by Protohistoric/Historic Plains Indian groups is evidenced in historic records and by the numerous Garza County rock art sites that contain historic Plains Biographic Style motifs.

\section{RESEARCH ORIENTATION}

Archeological research in the southern Lower Plains has not been extensive, and the Justiceburg Reservoir studies constitute the region's largest single archeological data base. In conjunction with the Phase II investigations at Justiceburg, detailed prehistoric and historic research designs were developed to provide the necessary foundation for assessing site significance relative to regional research problems.

\section{Prehistoric Investigations}

A model of late Holocene human adaptation was proposed for the prehistoric archeological investigations (Boyd, Abbott et al. 1990:261-273; Boyd, Tomka et al. 1990). The model, based on work by Binford (1980), Hayden (1986, 1987), and Kelly $(1980,1983)$, suggests that human subsistence strategies and settlement patterns are controlled in large part by resource distribution and that human social groups exploit resources using some combination of two different resource-acquisition patterns, i.e., as logistically oriented collectors or residentially mobile foragers. More specifically, the model proposes that a single resource, bison, is the main factor conditioning the selection of subsistence strategies and landuse patterns in the Lower Plains. The model suggests that climatic changes caused bison populations to fluctuate through time and that it was the abundance or scarcity of bison that controlled human subsistence strategy selection. Bison are viewed as the only sufficiently stable bulk resource in the Lower Plains that feasibly could be exploited by humans under a logistically oriented collector strategy. During times of bison abundance, such as proposed for the late Archaic and Late Prehistoric II periods, human populations would act as logistical collectors to exploit the bison but would also exploit a wide range of other resources as foragers. In times of bison scarcity, such as proposed for the Late Prehistoric I period, human populations would operate exclusively as foragers and exploit a wide range of less-abundant and less-dependable resources. This is not to say that a single group always practiced either a forager or a collector strategy; in contrast, human groups are dynamic and flexible in their resource procurement, and it is expected that subsistence strategies were shifted to accommodate a fluctuating resource base (e.g., seasonal availability of resources). It is suggested, however, that the subsistence strategy practiced by a single human group at any given point in time does, in fact, fit somewhere in the collectorforager continuum.

The practical utility of this model lies in the fact that different types of sites, both quantitatively and qualitatively, are generated under these different resource-acquisition patterns. For example, only two site types (residential base camps and locations) are generated by a forager system, while several different site types (residential base camps, field camps, locations, stations, and caches) would be generated within a collector-oriented strategy. In addition, the residential base camps and locations generated under different strategies should be substantially different. Furthermore, these differences should be archeologically recognizable. Thus, the immediate goal of archeological research is to determine how individual sites fit within the collector-forager continuum, and the long-range goal is ultimately to identify, through intersite studies, the relationship between resource structure and land-use patterns through time and space.

The model summarized above provides the theoretical framework for evaluating the prehistoric 
sites recorded during this project. The two factors that must be considered are site integrity and potential for contributing data useful for addressing the general hypotheses and specific research questions generated by the model. Four major research topics have been defined as settlement patterns, subsistence, site structure, and material culture. Within each of these topics, a series of general hypotheses and specific research topics are proposed (Boyd, Tomka et al. 1990:38-46).

The general hypotheses are directly related to the theoretical model of late Holocene human adaptation and deal with a regional level of interpretation. Within each research topic, two general hypotheses are proposed; the first describes archeological expectations under a collector-oriented resource procurement strategy, and the second describes the expectations under a residentially mobile forager system. All of the general hypotheses proposed by Boyd, Tomka et al. (1990:38-42) are repeated in their original form below.

\section{Settlement Patterns}

\section{GENERAL HYPOTHESIS 1a}

Residential base camps within collector systems may be either single-season camps oriented toward procurement and processing of bison or multiseasonal base camps that were bison oriented on a seasonal basis but geared toward foraging for supplemental plant and animal resources during other parts of the year. In either case, lengthy site occupations and/or yearly reoccupations are likely, and low residential mobility and relatively high populations should be evident by site size, overall frequency of cultural materials and features, and intensity of site use. The presence of a relatively high percentage of nonlocal lithic materials and other exotic trade items may indicate large territory exploitation and participation in interregional exchange networks.

Logistically oriented collector systems may also include residential base camps that were season specific and oriented toward foraging for specific resources. Within the overall context of a collectordominated system, some residential base camps may have been solely foraging oriented and hence would appear no different archeologically than those described below.

\section{GENERAL HYPOTHESIS $1 b$}

Residential base camps within an exclusively forager system should exhibit archeological evidence of highly mobile, relatively short term, seasonspecific occupations, although reoccupation on a seasonal basis is also likely. The sites served as base camps for daily foraging activities exploiting specific resource patches. It is possible that a single site may have been oriented toward a single resource, although it is more likely that multiple resources were exploited from a single base camp. Exclusive foragers exploited a relatively small overall territory that should be evident archeologically by low percentages of nonlocal lithic materials and few exotic trade items.

\section{Subsistence}

\section{GENERAL HYPOTHESIS 2a}

Residential base camps that operated within a logistically oriented collector system will exhibit multiple lines of evidence of bulk procurement and processing of a dominantly high-yield (large biomass) resource, which is bison in this case. Exploitation of other plant and animal resources probably will be evident in the flora and fauna recovered. The overall faunal assemblages, however, will be dominated by bison and will be biased toward high-meatyield body parts (e.g., ribs, scapulas, and femurs) that were selectively transported from kill sites back to the camps. Food storage of bulk resources is characteristic of collector systems but is not likely to include storage pits at bison-oriented sites. Meat drying and/or salting for storage were probably important activities at bison-oriented collector sites but may be difficult to recognize archeologically (e.g., post molds indicating drying racks).

\section{GENERAL HYPOTHESIS $2 b$}

Residential base camps generated by a forager system will exhibit evidence of exploitation of a diverse range of relatively low yield (small biomass) resources. Faunal assemblages will be diverse and may include deer, numerous small mammals such as rabbits and rodents, turtle, fish, etc. A low percentage of bison may be represented, but the overall 
faunal assemblage will not be dominated by any one resource. Macrobotanical and pollen remains will represent a diverse range of plant foods.

\section{Site Structure}

\section{GENERAL HYPOTHESIS 3a}

Bison-oriented collector base camps will have well-defined site structure with spatially discrete activity areas and special-function features related to bison processing. Specific activity areas might include hide processing stations with evidence of unifacial scraping tool rejuvenation, tool manufacturing areas where the final stages of lithic reduction occurred, secondary butchering areas where selected cuts were further processed, bone-grease manufacturing areas, and cooking areas where bison and/or other resources were prepared. Activity areas will be identifiable as high-frequency clusters of artifacts and/or faunal and floral remains. Horizontal patterning of activity areas may even provide evidence of community-level organization (i.e., habitation areas or structures). Due to the increased length of occupation, more-frequent site maintenance activities may have generated well-defined midden areas at these sites.

\section{GENERAL HYPOTHESIS $3 \mathrm{~b}$}

Residential bases camps generated within an exclusively forager system will be characterized by multifunctional and overlapping features and activity areas representing exploitation of a single resource or contemporaneous exploitation of multiple resources. Site reoccupation for exploiting different resources at different times is also likely. Although individual base camps may exhibit various degrees of specialization, overall these sites will appear unspecialized due to the similarities in the procurement and processing strategies and material culture for exploiting various low-yield plant and animal resources.

\section{Material Culture}

\section{GENERAL HYPOTHESIS 4a}

Material culture assemblages at bison-oriented collector residential base camps will include special- ized tools reflecting the importance of bison hunting (projectile points), meat processing (cutting tools such as beveled knives), and hide processing (scraping tools such as end scrapers). Manufacture and rejuvenation of these tools will be important activities represented in the lithic debitage and in staged preforms. It is expected that hide processing may be particularly well represented in campsites, and resharpening of unifacial hide-scraping tools should be evident. Lithic debitage should reflect a strategy of nonlocal material procurement and transportation of early-stage tools to base camps for the final stages of tool manufacture. Specifically, the debitage should exhibit a high percentage of nonlocal materials and a disproportionately high frequency of decorticate flakes.

\section{GENERAL HYPOTHESIS $4 b$}

Forager residential base camps will be characterized by a generalized stone tool assemblage and dominance of local material use. Chipped stone tools will be dominated by multifunctional and expedient tools, i.e., various types of bifacial and unifacial cutting and/or scraping tools exhibiting considerable morphological variability. Lithic debitage will be dominated by local materials, and all stages of lithic manufacture will be evident by the presence of cores and complementary percentages of corticate and decorticate flakes.

\section{Specific Research Questions}

The general hypotheses are theoretically oriented and broad in scope. A regional interpretation is an appropriate first level of organization for the prehistoric research design for Justiceburg Reservoir. Because these hypotheses are so generalized, however, they are practical for interpreting large data sets which can only be generated by numerous individual sites and projects within a region. Thus, the practical approach for initially interpreting most archeological data is to develop specific research questions which can be "subjected to empiral testing" (Goodyear et al. 1978:163). Specific research questions are particularly useful since they can be addressed realistically by the data generated by a single archeological project. A series of 22 specific research questions was developed to serve this purpose (Table 1). 


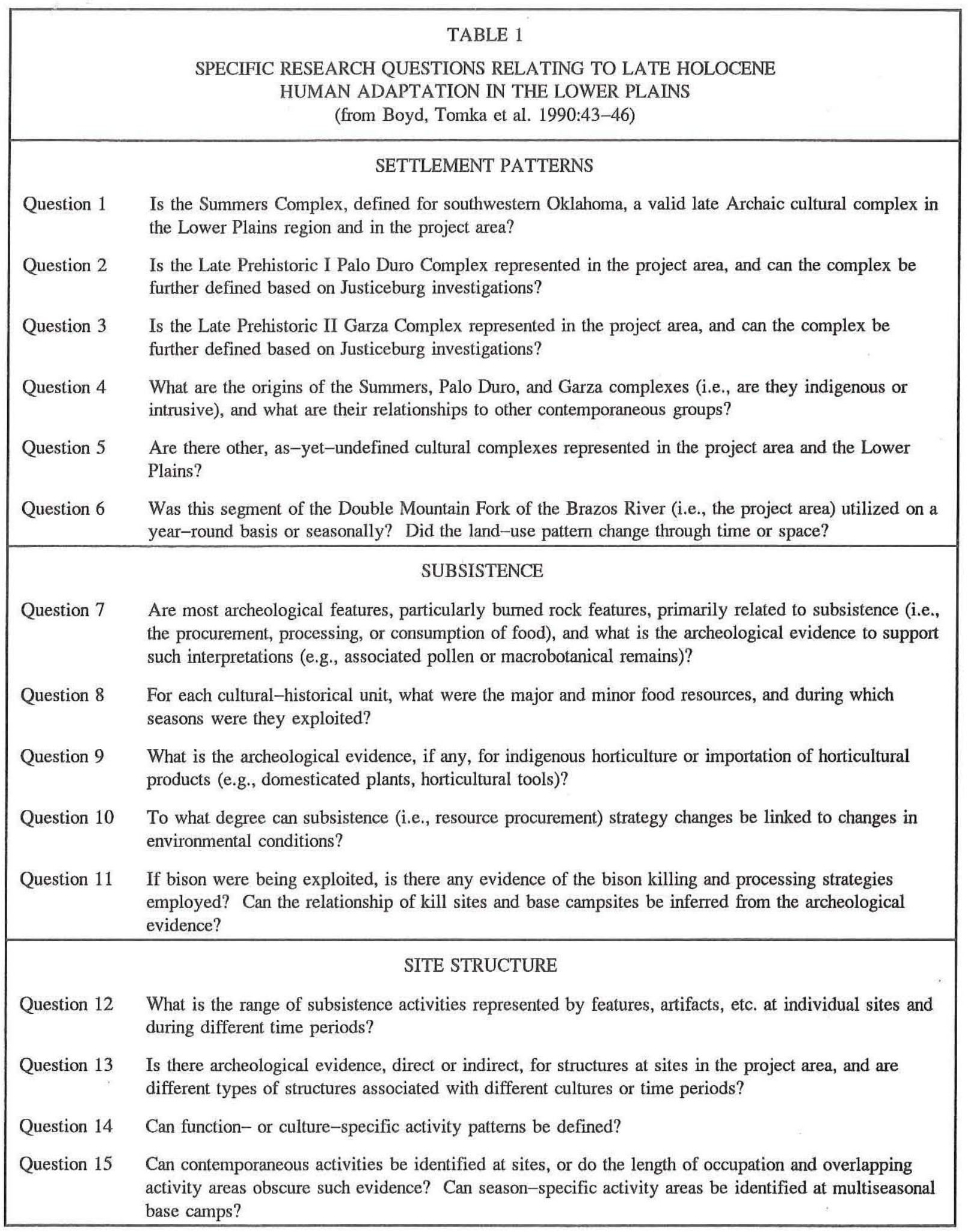




\begin{tabular}{|c|c|}
\hline & MATERIAL CULTURE \\
\hline Question 16 & $\begin{array}{l}\text { What impact did stone tool technology (e.g., the introduction of the bow and arrow) have on resource } \\
\text { procurement? }\end{array}$ \\
\hline Question 17 & $\begin{array}{l}\text { Does stone tool technology (i.e., lithic reduction strategy) change through time, or are different } \\
\text { technologies characteristic of different cultures? }\end{array}$ \\
\hline Question 18 & $\begin{array}{l}\text { Are gouges representative of single or multiple time periods, and are they single-function or multi- } \\
\text { functional tools? }\end{array}$ \\
\hline Question 19 & $\begin{array}{l}\text { What frequencies of tools are associated with various activities (e.g., plant and animal procurement/ } \\
\text { processing), and how do these frequencies compare from site to site? }\end{array}$ \\
\hline Question 20 & $\begin{array}{l}\text { What is the nature of the local lithic resource procurement and utilization patterns, and what is the } \\
\text { relative importance of nonlocal lithic resources? Do these change through time or space? }\end{array}$ \\
\hline Question 21 & $\begin{array}{l}\text { Is there any direct evidence (such as associated pollen) that ground stone tools were primarily used for } \\
\text { plant processing? If so, can the relative importance of plant foods within the overall subsistence } \\
\text { strategy be interpreted from the ground stones? }\end{array}$ \\
\hline Question 22 & $\begin{array}{l}\text { What is the role of ceramics within sites (i.e., cooking vs. storage)? Can the relative importance of } \\
\text { storage in ceramic vessels be determined? }\end{array}$ \\
\hline
\end{tabular}

\section{Historic Investigations}

For the historic resources, two comprehensive regional historic contexts were developed as part of the Phase II investigations at Justiceburg Reservoir. One of the historic contexts, "Buffalo Hunting on the Rolling Plains, 1874-1879" (Freeman 1990a), falls within a general theme suggested by the Texas Historical Commission entitled "Natural Resources Exploitation and Development." This context, however, is not applicable to evaluating the resources encountered in the wildlife mitigation survey and is not considered further here. The second context, "Ranching on the Western Rolling Plains, 1877-1945" (Freeman 1990b), falls within another Commissiongenerated thematic context, "Agriculture in Texas," and is important for assessing site significance for this project.

Ranching in the westem Rolling Plains area began in the late 1870 s at a time when hostile Indians and large buffalo herds were disappearing. Utilization of the area accelerated during the early 1880 s as numerous ranchers from the Cross Timbers region moved their cattle herds westward to take advantage of the abundant grasses and springs and of the canyons that afforded shelter to their animals. While cattle were the most frequently raised animals, a few ranchers brought sheep with them; however, the occurrence and distribution of that animal in the region is poorly documented.

Favorable markets and weather resulted in a florescence of ranching on the westem Rolling Plains between 1879 and 1885 . For the most part, ranching was carried on by a combination of individually owned and company-owned outfits that grazed animals on sections leased from railroad companies and the State of Texas. In a few cases, ranchers filed claims to sections along major water courses such as Grape Creek, but leases sufficed for the most part. Some ranchers brought their families with them; more commonly, headquarters were occupied by single males who hired other young men to work as hands on the range where they lived in shelters such as dugouts.

Goods and materials were acquired during the early years from Fort Griffin, Weatherford, and Fort Worth, and the few small stores in the region that were a legacy of the buffalo range of the 1870 s. By 1881, however, most supplies came from Colorado City, a community that was established in anticipation of the construction of the Texas and Pacific Railroad from Fort Worth and eventually had the greatest impact on Rolling Plains ranching. Between 1881 when the first train arrived at the townsite and the 
mid 1880s when unfavorable weather and competition from other towns triggered an economic collapse, Colorado City was the shipping and supply headquarters for West Texas, serving ranches in a 27-county region. The nearest trade competitors were Dodge City, Kansas; Springer, New Mexico; and Trinidad, Colorado, which supplied the northern Texas Panhandle (Jones and Cline 1940:33, 36, 38, 40, 43, 47, 49, 51, 59; Hendrix 1941:35, 36; Jones and Richardson 1943:39).

The connection between Colorado City and the western Rolling Plains was strong, with individuals such as "Uncle Pete" Snyder, who had built a store on Deep Creek in Scurry County to supply buffalo hunters, later moving to Colorado City; and other Rolling Plains ranchers either making their permanent homes in the town or visiting there frequently. However, boom turned to bust by the late 1880 s following a period of blizzard and drought, and the economic situation worsened after the national panic of 1893 . By the late 1880 s, Colorado City in particular and the Rolling Plains in general had experienced an economic collapse, and while the region regenerated by the turn of the century, Colorado City never regained its prominence.

Just as weather and economic issues affected the Rolling Plains, so also legal issues affected the ranching industry there. In 1895, the State Legislature passed the Four-Section Act. Designed to encourage permanent settlement and the acquisition of homestead tracts from the State, the Act forced openrange ranchers who had leased land for grazing to develop innovative methods of controlling sections that were sure to be purchased by new homesteaders from outside the immediate area. Many ranchers and ranching companies managed to retain their ranges for several years by encouraging employees to file on four sections. Assistance was provided to the employee when the ranch owner made the yearly payments required by the State and paid county taxes on the parcel as well. For their part, the employees agreed to allow the ranch owner to run his cattle on the sections. In addition, some hands agreed to allow the rancher or ranch company the privilege of first refusal should the hand decide to sell the sections. Hands who filed homesteads under such agreements usually remained employees of the larger ranch but were obligated to fulfill the terms of their agreement with the State by building improvements on the homestead section and occupying that section for three years.

Various property types were associated with Ranching on the Western Rolling Plains from 1877 to 1945. During the open-range period, ranch headquarters and line camps were the most prominent property types. During the closed-range ranching period, the homestead/ranch headquarters was the common property type, and quite frequently a single property may have been occupied and in use during both periods.

Specific kinds of structures and features characterize the ranching period sites in the Rolling Plains. The dugout was by far the most common structure associated with the ranching period, followed by above-ground homes. During the open-range period, dugouts frequently functioned as line camps and often served as temporary ranch headquarters until a more permanent structure, usually a wood frame or rock house, could be constructed. The dugout also was a common structure associated with closed-range ranching since almost all new homesteaders constructed at least temporary dugouts before building permanent homes. Other features associated with ranching properties in the region included fences and corrals for horses and cattle; wells, windmills, water tanks, and stock ponds to provide water for home or livestock use; and outbuildings such as tack rooms for equipment storage and covered sheds for protecting livestock from severe weather.

This historic context is intended to place the ranching sites in the Justiceburg Reservoir area within the context of the broader historic patterns that created them and to establish the identity and extent of other comparable cultural properties. The context is also essential for outlining the property types included within the region in general and the project area specifically. These property types are described, their significance defined, and the requirements for their registration listed. Factors which are taken into consideration include the integrity of the property and completeness of its components, and the extent to which the property addresses the four National Register criteria. 


\section{ARCHEOLOGICAL SURVEY}

by Douglas K. Boyd and Martha Doty Freeman

The archeological survey constituted the major portion of the cultural resources investigation of the wildlife mitigation lands and consisted of a $100 \%$ pedestrian survey of approximately $54 \%$ of the ca. 2,240 acres and a visual spot check of the remaining upland areas (see Fig. 1). The methods and results of the archeological survey are described below.

\section{METHODS}

Prefield tasks completed prior to the start of the survey included a review of archeological records at the Texas Archeological Research Laboratory (TARL) to identify previously recorded sites, a review of previously compiled historical documentation to identify potential historic sites, and a preliminary geomorphic assessment of the wildlife mitigation tract. The TARL records confirmed that there was only one previously recorded site, prehistoric campsite 41GR481, within the survey area. The Project Historian had been told by an informant of a historic homestead in the survey area and began researching the location. The Principal Investigator and Project Geomorphologist reviewed air photos and topographic data to identify high and low site probability areas.

Field tasks included intensive and spot-check archeological survey, additional historic archival and informant research relating to the historic homestead, and geoarcheological reconnaissance and subsurface mechanical testing. The geoarcheological investigation is described separately in Chapter 4.

As discussed in Chapter 1, a decision was made to conduct intensive survey of all high-probability areas, i.e., the canyonlands and prominent upland rises, but only to spot check the upland flat and lowlying areas to assess their site potential. Field spot checking consisted of visual inspection to confirm the topography and low site probability of the selected upland areas. The assessment of flat and low-lying upland areas as having low site potential is based on intensive surveys of several upland areas during previous phases of work at Justiceburg. The chance of finding a site in the upland diminishes greatly with increasing distance from the canyon rim and stream valleys. Upland sites located some distance from the canyon rim are generally situated on high rises or on high ridges or dunes surrounding playa depressions. In all cases, it was determined that the spot-check areas are low-lying or flat uplands with little potential for prehistoric sites. In addition, the majority of the low-probability uplands are located in the western portion of the project area which is completely overgrown with cholla and prickly pear due to root plowing. This dense vegetation would have prevented any attempt at pedestrian survey.

The intensive survey of the incised canyonlands and selected upland areas was conducted by a crew of four archeologists walking transects, either spaced at ca. 30-m intervals or following the valley topography (e.g., bluff edges and stream terraces). Past survey work at Justiceburg has indicated that off-site shovel testing is not an effective method of site discovery in any setting (Boyd et al. 1989:196-197) because buried archeological deposits are almost always evident in various natural (e.g., cutbank 
erosion and animal burrows) and/or artificial (e.g., roadcuts and buried pipelines) exposures. Hence, off-site shovel testing was not incorporated into the survey methodology, and the survey concentrated on exposures of buried sediments. The exception to this was along the bluff edge where shovel probes and shovel tests were used consistently to determine the nature and depth of the deposits in overhangs and rockshelters. Shovel probes are quick excavations to determine the depth of sediments, while shovel tests are controlled excavations in which all sediments are screened through 1/4-inch-mesh hardware cloth.

When archeological materials were discovered, a thorough reconnaissance of the area was made, and if necessary, shovel probes or shovel tests were excavated to determine whether the materials warranted recording as sites or as isolated finds. As in the original survey of the reservoir area, isolated finds were defined as any single surface artifact or feature with no associated materials or features, or surface sites with a density of cultural materials of less than one item in $20 \mathrm{~m}^{2}$. These finds are interpreted as highly disturbed, redeposited, or otherwise lacking intact context, and every attempt was made to confirm that isolated surface finds were not associated with buried cultural remains. Each isolated find was briefly described, and its topographic setting, elevation, and location were noted.

All archeological sites were recorded on State of Texas Site Data Forms, a temporary field site number was assigned, and the site was plotted on a USGS 7.5' topographic map. At least one blackand-white print and one color slide was taken of each site, and additional photographs were taken if unique or unusual features were encountered.

A paced sketch map was made for each site. The site topography was mapped, and all cultural features (such as hearths and bedrock mortars), unique artifacts, and manmade features or disturbances were plotted. Sites such as surficial lithic procurement areas were not mapped in great detail, but complex and unique sites or parts of sites were mapped in correspondingly greater detail. A 12-inch rebar site datum was established, and the site or area was mapped from this point using angle/distance measurements. Short distances were paced or taped, and longer distances were calculated using an optical rangefinder.

Only a very few selected diagnostic artifacts were collected, and when an artifact was collected from an apparently undisturbed context and was possibly associated with other artifacts or features, a 17- $\mathrm{cm}$-long nail was placed at the location to mark it for future reference. All collected artifacts were plotted on site maps and bagged by provenience.

On-site shovel probes or shovel tests were excavated as needed to determine the nature and extent of the deposits. No shovel tests were done if the archeological deposits were obviously surficial, such as at lithic procurement sites, or if erosional cutbanks or other exposures provided adequate information on the buried deposits. The shovel tests were approximately $30 \times 30 \mathrm{~cm}$ and were screened through 1/4-inch-mesh hardware cloth and recorded in 10-cm levels. For each on-site shovel test, a Testing Data Form was completed, an aluminum disc was placed at the bottom, and the test was backfilled. All cultural materials recovered in shovel tests were collected and bagged by provenience with the exception of burned rocks which were recorded but not collected.

\section{RESULTS OF THE SURVEY}

Based on the results of the Justiceburg Reservoir survey, it was predicted that ca. 35 prehistoric sites would be discovered in the wildlife mitigation tract. The wildlife mitigation archeological survey came very close to the prediction and resulted in the documentation of 32 prehistoric sites ( 1 of which was previously recorded) and 1 historic site. These sites (prehistoric sites 41GR481, 41GR572 through 41GR585, and 41GR587 through 41GR603; historic site 41GR586) are described in detail below. In addition, eight isolated finds were recorded (Table 2). In conjunction with these investigations, 27 prehistoric artifacts were collected and these also are described later in this chapter.

\section{Archeological Sites}

The single historic site documented during the survey is classified as a homestead associated with the closed-range ranching period. Of the 32 prehistoric archeological sites, 6 are classified as lithic procurement areas, 12 are open campsites, 12 are combination campsite/lithic procurement areas, 1 is a lithic scatter, and 1 is a faunal locality. These site types are defined in Boyd et al. (1989:108-109) but are briefly summarized here. A lithic procurement area is a natural outcrop of Quaternary (Lingos formation) gravels which exhibits use as a lithic 


\begin{tabular}{|l|l|l|l|}
\hline \multicolumn{5}{|c|}{ SUMMARY OF ISOLATED FINDS } \\
\hline IF No. & Description & $\begin{array}{l}\text { Elevation } \\
\text { ft msl) }\end{array}$ & Setting \\
\hline $1 *$ & Fist-sized quartzite hammerstone & 2220 & Bluff edge overhang \\
\hline 2 & $\begin{array}{l}\text { Potter chert flake and few fire-cracked Potter } \\
\text { chert fragments }\end{array}$ & 2180 & Gully at base of talus slope \\
\hline 3 & Fist-sized quartzite core & 2200 & Gravel terrace near talus slope \\
\hline 4 & One Potter chert and two quartzite flakes & 2300 & Gravel outcrop on upland margin \\
\hline 5 & One chert and three Potter chert flakes & 2320 & Low swale, upland ephemeral drainage \\
\hline 6 & Historic graffito "D. DODSON. AUG 19 1943" & 2300 & On sandstone bluff near major spring \\
\hline 7 & Ca. 10 flakes of Potter chert and quartzite & 2250 & Gravel outcrop on upland margin \\
\hline $8 *$ & Unifacial gouge/pebble tool & 2345 & Edge of upland rise \\
\hline$*$ Collected. & & \\
\hline
\end{tabular}

source area or which contains evidence of early-stage lithic reduction (e.g., cores, tested cobbles, flakes, and hammerstones). An open campsite is distinguished by the presence of burned or fire-cracked rocks, evidence of later stages of lithic reduction, and occasional finished tools. Combination campsite/ lithic procurement areas exhibit the same evidence of campsite activities at the location of a utilized gravel outcrop. A lithic scatter consists of chipped stone lithic debris of various stages, but burned or firecracked rocks are sparse or absent and the location is not associated with a gravel outcrop. A faunal locality consists of large mammal bones without definite associated cultural materials and could represent either a cultural or natural occurrence.

\section{GR481}

Site 41GR481 is a campsite of undefined prehistoric age initially recorded during the 1987 survey of the reservoir area (Boyd et al. 1989:516). At that time, a sparse lithic scatter consisting of a Potter chert chopper, flakes, and burned rocks was observed over a large (ca. $200 \times 300 \mathrm{~m}$ ) area. No features were observed, the site lacked evidence of subsurface deposits, and it was assessed as having a low research potential and recommended as not eligible for listing on the National Register of Historic Places. The current investigation consisted of a surface investigation, rerecording of the site, and excavation of a backhoe trench.

This site is situated on an upland rise ca. $350 \mathrm{~m}$ south of an east-flowing, spring-fed drainage. It covers most of the oval-shaped rise, a somewhat smaller area than was originally estimated (ca. $225 \times 100 \mathrm{~m}$ ) and is at an elevation of $2320 \mathrm{ft} \mathrm{msl}$. Vegetation consists of a moderate to heavy grass cover with mesquite, cholla, prickly pear, yucca, and various forbs. Bare spots and a two-track road through the site provide good surface exposure.

Cultural materials are concentrated in the central portion of the rise, near where the backhoe trench was located, and appear to be surficial or shallowly buried. As originally observed, materials consist of sparse lithic tools, debitage, and a few burned rocks, but no features were reported. Lithic tools observed include two biface fragments and a sandstone mano. The backhoe trench (Profile 14, see Chapter 4 and Appendix) did not yield any cultural evidence.

The site occupation is interpreted as an ephemeral, temporary campsite, and this investigation concurs with the original assessment that 41GR481 has a low research potential and is not eligible for listing on the National Register of Historic Places. 


\section{$41 G R 572$}

Site 41GR572 is a lithic procurement area of undefined prehistoric age located along the upland margin overlooking the confluence of two ephemeral drainages to the north. The site is at elevation 2240$2290 \mathrm{ft} \mathrm{msl}$ and follows the Quaternary Lingos gravels which naturally crop out along the eroding canyon rim. It is ca. $150 \mathrm{~m}$ south of the stream channel at its closest point. Vegetation cover, consisting of grasses, juniper, mesquite, yucca, prickly pear, and various forbs, is moderate to heavy in some areas but is very sparse in eroded portions of the site. Bedrock sandstone is exposed all along the edge of the canyon rim. The size of the site is ca. $250 \mathrm{~m}$ east-west by $50 \mathrm{~m}$ north-south.

The cultural materials observed consist of cores; tested cobbles; primary, secondary, and tertiary flakes; and hammerstones. All are of locally available quartzites, Potter chert, and chert. No features were observed, but a few Potter chert fragments appear to be fire cracked. All of the artifacts are surficial, and there is no potential for intact buried deposits. Furthermore, the gravel outcrop appears to have been only moderately utilized as a lithic source area. Site 41 GR572 is considered to have a low research potential, and it is assessed as not eligible for listing on the National Register of Historic Places.

\section{$41 G R 573$}

Site 41GR573 is a lithic scatter of undefined prehistoric age located on the upland margin on the south canyon rim above an east-flowing, spring-fed drainage. The site is at an elevation of $2260-2280 \mathrm{ft}$ $\mathrm{msl}$ and is less than $50 \mathrm{~m}$ from the stream channel. Vegetation consists of a moderate cover of juniper, mesquite, and grasses with some cholla, prickly pear, and catclaw acacia. Surface visibility is good in eroded areas, and considerable bedrock sandstone is exposed all along the rim edge. The site covers ca. $50 \times 50 \mathrm{~m}$.

Cultural materials consist of a very sparse scatter of lithic debitage, mostly Potter chert flakes, and tools. Three unifacial tools (two gouges and a scraper) were collected; no others were observed. One possible fire-cracked Potter chert fragment also was observed. All of the cultural materials are surficial, and shovel probes indicate that there is only a few centimeters of sediment accumulated in small pockets. No Lingos gravels are exposed in the site area, but utilized outcrops are located nearby (41GR572).

This site is interpreted as an isolated lithic scatter (possibly representing some specialized food procurement/processing activity) that may be associated with a nearby open campsite (41GR599). It has no potential for buried deposits and is considered to have a low research potential. It is recommended that site 41GR573 is not eligible for listing on the National Register of Historic Places.

\section{GR574}

Site 41GR574 is an open campsite of undefined prehistoric age situated on an erosional bedrock remnant in the valley of the main south-flowing ephemeral drainage. The site is at an elevation of $2220 \mathrm{ft}$ msl and is ca. $100 \mathrm{~m}$ west of the main drainage and immediately north of a smaller westflowing drainage. The erosional remnant is situated in a wide area in the valley ca. $6 \mathrm{~m}(20 \mathrm{ft})$ below a

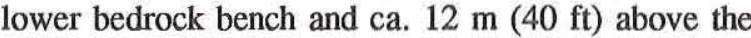
stream channel. The bedrock remnant forms a roughly circular hill consisting mainly of weathered mudstone, but a small area is capped with broken and weathered sandstone slabs. Vegetation at the site is sparse and consists of grasses, mesquite, juniper, cholla, yucca, and prickly pear. Site size is ca. 40x40 m.

The cultural materials observed consist of a very sparse scatter of coarse-grained quartzite flakes and fire-cracked Potter chert fragments. No features were observed, and the site area is severely eroded/ deflated with only small pockets of sediment preserved. Most of the site area is exposed bedrock, and there is no potential for buried remains. Site 41GR574 is considered to have a low research potential and is assessed as not eligible for listing on the National Register of Historic Places.

\section{GR575}

Site 41 GR575 is a faunal locality of unknown age. The faunal remains are exposed in an erosional gully just east of the main south-flowing ephemeral drainage. The site is at an elevation of $2190 \mathrm{ft} \mathrm{msl}$ and is less than ca. $2 \mathrm{~m}(2.5 \mathrm{ft})$ above the streambed. The alluvial terrace is very narrow in this area, and the faunal remains are less than $10 \mathrm{~m}$ west of the bedrock talus slope of the valley wall and less than 
$15 \mathrm{~m}$ east of the stream channel. There is considerable exposure in the vicinity by both cutbank and sheet erosion. Vegetation is sparse and consists of juniper, mesquite, grasses, prickly pear, catclaw acacia, and various forbs. The faunal remains are confined to a ca. 2-m area within a small (ca. $20 \times 20 \mathrm{~m}$ ) terrace remnant exposed by erosion on three sides.

No cultural materials were observed despite the excellent erosional exposure in the vicinity. The faunal remains consist of bison bones exposed at ca. 20-30 $\mathrm{cm}$ below the eroded surface of the terrace. A shovel test $2 \mathrm{~m}$ back from the exposed bones was negative, indicating that the bones were confined to a very small area. The exposed bones in the cutbank and in the talus slump were collected, and the cutbank was troweled to expose the in situ bones. Several additional bones, including a mandible fragment and a partially articulated lower leg, were collected for species/age identification and possible radiocarbon dating and carbon isotope studies. The bones were lying horizontally in a semiarticulated position, but no butcher marks were observed.

Rick Toomey of the Vertebrate Paleontology Laboratory at The University of Texas at Austin inspected the bones and provided the following information. All of the collected elements appear to be from a single modern bison. The articulated group represents a right lower foreleg and includes a metacarpal, a magnum, two first phalanges, two sesamoids, and a scaphoid. Miscellaneous nonarticulated elements include a radius fragment, a second phalanx fragment, various carpal fragments, rib fragments, a scapula blade fragment, and numerous unidentifiable fragments. A left mandible, uncovered intact but now fragmented, includes four teeth in series-P4, M1, M2, and M3. Collectively, the elements represent a fully mature adult of unknown sex and an estimated biological age of ca. 4-6 years. The criteria for this assessment are the complete fusion of the metacarpal and the slight to moderate wear on the M3.

This faunal locality is interpreted as a probable isolated natural death, but the possibility of cultural involvement cannot be ruled out entirely. The current investigation strongly suggests that no cultural materials are associated and that there is very little left of the single animal. The collected bone samples may provide useful chronological or environmental data, but the site itself retains little research potential. Site $41 \mathrm{GR} 575$ is assessed as not eligible for listing on the
National Register of Historic Places.

\section{$41 G R 576$}

Site 41 GR576 is a lithic procurement area of undefined prehistoric age situated on a lower bedrock bench terrace on the east side of the main southflowing drainage. It is located in a wide portion of the valley ca. $250 \mathrm{~m}$ east of the stream channel. Vegetation at the site is sparse and consists of juniper, mesquite, grasses, prickly pear, and various forbs. There is excellent erosional exposure over most of the site, and bedrock mudstone or sandstone outcrops are extensive. Quatemary Lingos formation gravels are exposed in clusters of varying density over the entire site area. The site is at an elevation of $2260-2280 \mathrm{ft} \mathrm{msl}$ and covers a ca. $50 \times 100-\mathrm{m}$ area.

Cultural materials consist of cores, tested cobbles, flakes, and hammerstones of local quartzites, Potter chert, and chert. All of the artifacts were found on the surface in areas where gravels are exposed. Most of the gravels are relatively small, the majority being fist-sized or smaller, but there are very dense concentrations (ca. 50 fist-sized nodules/ $\mathrm{m}^{2}$ ). There appears to have been moderate to intensive utilization of these materials. The site sediments are confined to shallow pockets of sand, and there is no potential for buried cultural deposits. Site 41GR576 is considered to have a low research potential and is assessed as not eligible for listing on the National Register of Historic Places.

\section{GR577}

Site 41GR577 is a lithic procurement area of undefined prehistoric age situated on the upland margin along the east canyon rim of the main southflowing drainage. The site is confined to the eroded canyon rim where relatively sparse quantities of Quaternary Lingos gravels are exposed. Vegetation cover is of low to moderate density and consists of mesquite, juniper, grasses, and various cacti and forbs. There is extensive erosional exposure with sandstone bedrock cropping out over most of the site. The site is at an elevation of $2260-2290 \mathrm{ft} \mathrm{msl}$ and covers a ca. 50x100-m area.

The cultural materials are of very low density. Only ca. 20 cultural items, cores, tested cobbles, flakes, and a possible hammerstone, were observed. The sparse nature of the cultural materials corre- 
sponds with the low density of gravel outcrops. All of the cultural materials are of local quartzites and Potter chert and are surficial. There is no potential for buried cultural deposits, and the site is considered to have a low research potential. Site 41 GR577 is assessed as not eligible for listing on the National Register of Historic Places.

\section{$41 G R 578$}

Site $41 \mathrm{GR} 578$ is an open campsite/lithic procurement area of undefined prehistoric age. It is situated along the eroding upland margin on the east side of the main south-flowing drainage and is ca. $100 \mathrm{~m}$ east of and $24 \mathrm{~m}$ (ca. $80 \mathrm{ft}$ ) above the stream channel. It is only $0.5 \mathrm{~km}$ from a large freshwater spring. A thin scatter of Quaternary Lingos gravels is exposed all along the canyon rim. Vegetation on the site is dominantly grasses, juniper, and mesquite, with lesser amounts of agarita, cholla, prickly pear, yucca, and various shrubs. The site is at an elevation of 2240-2300 ft msl and covers ca. $100 \mathrm{~m}$ east-west by $300 \mathrm{~m}$ north-south.

No features were observed, but cultural materials consist of scattered fire-cracked Potter chert, flakes of quartzite and Potter chert, and a few stone tools. The tools include a quartzite hammerstone fragment, a thick Potter chert biface, and a Potter chert uniface; the latter was collected. Overall, the site has a relatively low density of materials which corresponds with the low density of exposed gravels. There is no hint of buried cultural materials along the uppermost eroding edge of the uplands, and the majority of the materials are exposed in the severely eroded lower portions of the site where there is no potential for buried cultural deposits.

The site is interpreted as a lithic procurement area with minimal evidence (scattered burned rocks only) of camping activities. Site 41GR578 is assessed as not eligible for listing on the National Register of Historic Places.

\section{GR579}

Site 41GR579 is an open campsite/lithic procurement area of undefined prehistoric age. It is situated along the upland margin and downslope onto an eroded lower bedrock bench terrace on the east side of the main south-flowing drainage. It is ca. $100 \mathrm{~m}$ east of and $30 \mathrm{~m}(98 \mathrm{ft})$ above the stream channel, and $0.5 \mathrm{~km}$ downstream from a freshwater spring. Vegetation at the site consists of juniper, mesquite, grasses, catclaw acacia, prickly pear, cholla, and various forbs. Ground exposure is very good along the eroded canyon rim edge and over most of the lower bench. Moderate amounts of Quatemary Lingos gravels are exposed, mainly on the eroded lower bench. The site is at an elevation of 2260-2300 ft msl and covers a ca. 50x100-m area.

The cultural materials observed include evidence of lithic procurement (cores, tested cobbles, flakes, and hammerstones) but also bifacial and unifacial (scrapers) tools. In addition, two areas of scattered fire-cracked Potter chert are located on the eroded lower bench. Two possible features, both small (ca. $30 \times 30 \mathrm{~cm}$ ) clusters of fire-cracked Potter chert fragments, were noted. Several lithic tools (a quartzite hammerstone, two Potter chert unifaces, and a quartzite core) were noted within ca. $2 \mathrm{~m}$ of one of the features. It appeared that this feature was eroding out in situ, and thus a shovel test was excavated several meters upslope where there appeared to be intact sediments. One fire-cracked Potter chert fragment was found in the upper $10 \mathrm{~cm}$, and hard caliche or weathered bedrock was encountered at $20 \mathrm{~cm}$ below the surface. Although there appears to be a fair amount of cultural materials at this site, the severely eroded condition of the lower bench and the lack of any significant accumulations of sediment suggest that this site has very little potential for primary buried cultural deposits. Site 41GR579 is assessed as not eligible for listing on the National Register of Historic Places.

\section{GR580}

Site 41GR580 is an open campsite/lithic procurement area of undefined prehistoric age. It is situated on the upland margin and downslope onto a series of lower bedrock bench terraces immediately north of the confluence of two small drainages. It is only about $200 \mathrm{~m}$ from a major freshwater spring. Extensive outcrops of Quaternary Lingos gravels are exposed, mainly on the lower benches. Vegetation at the site consists of grasses, juniper, mesquite, prickly pear, and various forbs. The site is at an elevation of 2260-2300 ft msl and covers ca. $125 \mathrm{~m}$ north-south by $250 \mathrm{~m}$ east-west.

Cultural materials consist of evidence of lithic procurement (cores, tested cobbles, and flakes), unifacial tools (a scraper and a gouge were collected), several quartzite manos and mano/hammerstones, 
a sandstone metate fragment, and scattered firecracked Potter chert fragments. The fire-cracked rocks are found in concentrations covering several square meters, as if features were dispersed by erosion. Only one possible feature, a ca. $50-\mathrm{cm}-$ diameter cluster of fire-cracked Potter chert with no definitely associated artifacts, was observed. The lower benches are deflated to bedrock or very heavily eroded. A shovel test was excavated in an area where some accumulation of sediments was observed. Fire-cracked rocks were found in the upper $10 \mathrm{~cm}$, but the test was sterile from $10-40 \mathrm{~cm}$.

All of the cultural materials at this site are surficial or only very shallowly buried and are most concentrated in the severely eroded portion of the site. It appears that there is little potential for buried cultural deposits at this site, and even if such deposits could be located, it is likely that they would not be in a primary context. Site $41 \mathrm{GR} 580$ is considered to have a low research potential and is assessed as not eligible for listing on the National Register of Historic Places.

\section{GR581}

Site 41GR581 is a lithic procurement area of undefined prehistoric age situated along the upland margin and lower bedrock bench at the upper end of a small tributary drainage and is ca. $300 \mathrm{~m}$ from a major freshwater spring. A very light scatter of Quaternary Lingos formation gravels is exposed all along the eroding upland edge. Vegetation consists of grasses, juniper, mesquite, catclaw acacia, prickly pear, cholla, and various forbs. The site area is extensively eroded, and surface visibility is very good. The site is at an elevation of $2260-2310 \mathrm{ft}$ $\mathrm{msl}$ and covers a ca. $75 \times 100-\mathrm{m}$ area.

Cultural materials consist of a low-density scatter of cores and flakes of Potter chert and quartzite among the sparse gravels. All are surficial, and there is no potential for buried deposits. The site is interpreted as a minimally utilized lithic source area. It is certainly one of the lowest density gravel outcrops in the survey area but probably was convenient due to its close proximity to nearby campsites. Site 41GR581 is considered to have a low research potential and is assessed as not eligible for listing on the National Register of Historic Places.

\section{GR582}

Site 41 GR582 is a large open campsite/lithic procurement area of undefined prehistoric age situated along the upland margin and extensively eroded lower bedrock benches immediately adjacent to a stream channel and major freshwater spring. Quaternary Lingos gravels are exposed mainly along the eroding upland edge but are also redeposited onto all the lower bench areas. Vegetation density varies considerably across the site and consists of grasses, juniper, prickly pear, yucca, and various forbs. Hackberry and cottonwood trees are found in the spring area. The site is at an elevation of 2260$2320 \mathrm{ft} \mathrm{msl}$ and covers ca. $200 \mathrm{~m}$ north-south by $450 \mathrm{~m}$ east-west.

Cultural materials consist of evidence of lithic procurement (cores, tested cobbles, flakes, and hammerstones) and abundant evidence of camping activities. The latter is confined mainly to the lower bench areas and includes two bedrock mortars, numerous burned sandstone clusters (i.e., hearths), scattered fire-cracked Potter chert, several quartzite and sandstone manos, a sandstone metate fragment, bifacial and unifacial tools, and abundant lithic debitage. There appears to be good spatial integrity to the exposed artifacts and features and a good potential for intact buried cultural deposits in some areas of the lower benches. A backhoe trench (Profile 7, see Chapter 4 and Appendix) in the upland edge of the site yielded a fire-cracked rock at $23 \mathrm{~cm}$ below the surface, indicating considerable potential for buried cultural deposits. Although no diagnostic artifacts were recovered, this site has similar geomorphic and cultural characteristics to a nearby site (41GR583) that yielded a late Archaic dart point; it is likely that 41GR582 has a contemporaneous component. Site 41GR582 is likely to have a high research potential but cannot be fully assessed with the limited data available. It is recommended that the site be considered of unknown eligibility for listing on the National Register of Historic Places.

\section{$41 G R 583$}

Site 41GR583 is a late Archaic open campsite/ lithic procurement area situated on the upland margin and lower bedrock bench terraces immediately adjacent to a stream channel and major freshwater spring. The uplands are gently sloping, while the lower benches are heavily eroded. Quaternary Lingos gravels are exposed in varying concentrations along the upland edge and redeposited onto the lower benches. Vegetation consists of grasses, juniper, mesquite, yucca, catclaw acacia, prickly pear, and 
various forbs. Hackberry trees are found along the stream channel, and cottonwood trees grow in the spring area. This is an extremely large site, covering ca. $200 \mathrm{~m}$ north-south by $500 \mathrm{~m}$ east-west, at an elevation of 2260-2320 ft msl.

Cultural materials consist of evidence of moderate- to heavy-intensity lithic procurement (cores, tested cobbles, hammerstones, and flakes) of gravel concentrations and extensive evidence of camping activities. The latter includes a cluster of 15 bedrock mortars (there are probably more that are buried by sediment and vegetation), numerous burned sandstone hearths and scatters of fire-cracked Potter chert, quartzite manos, large Potter chert choppers, bifacial and unifacial tools, and abundant lithic debitage. In addition, a comer-notched Marcos dart point was collected.

The exposed cultural materials appear to be clustered into distinct activity areas. Several areas have potential for containing intact buried cultural deposits, and burned rock features in some areas are only partially exposed. The large number and sizes of the bedrock mortars suggests an intensive occupation. Two of the mortars are bisected by large cracks in the sandstone bedrock; one has had its two ends laterally displaced by ca. $10 \mathrm{~cm}$, suggesting that these features are quite old. If the assessment of late Archaic (for at least one component) is correct, it is likely that the bedrock mortars are associated with that component as well. Site 41GR583 is likely to have a high research potential but cannot be fully assessed with the limited data available. It is recommended that the site be considered of unknown eligibility for listing on the National Register of Historic Places.

\section{GR584}

Site 41 GR584 is an open campsite/lithic procurement area of undefined prehistoric age situated on an east-sloping upland margin and lower bedrock bench/alluvial terrace at the confluence of two small drainages which head in the uplands within ca. $2.5 \mathrm{~km}$ of the site. It is located ca. $300 \mathrm{~m}$ upstream from a major spring, and a smaller pool of water, possibly a minor seep spring, is located along the stream channel immediately adjacent to the site. Sparse Quatemary Lingos gravels crop out in the upper portion of the site. Vegetation consists mainly of grasses, juniper, and mesquite, with lesser amounts of catclaw acacia, cholla, prickly pear, and various forbs. Several varieties of trees, including hackberry and willow, are found along the stream channel. The site is ca. $100 \mathrm{~m}$ northeast-southwest by $250 \mathrm{~m}$ northwest-southeast and is at an elevation of 2280$2310 \mathrm{ft} \mathrm{msl}$. The adjacent stream channel is at an elevation of $2375 \mathrm{ft}$ msl.

Cultural materials include evidence of lithic procurement (cores, tested cobbles, and flakes) along the upper edge of the site. Extensive evidence of campsite activities consists of four bedrock mortars in the stream channel and numerous burned rock features exposed by cutbank and sheet erosion all along the edge of the stream channel. In one area in the southern portion of the site, intact alluvial sediments are present with buried intact burned rock features (sandstone hearths and a fire-cracked Potter chert cluster) and associated artifacts exposed in the upper $20 \mathrm{~cm}$. A shovel test a few meters back from the cutbank revealed an intact hearth feature at ca. $60 \mathrm{~cm}$, indicating that the cultural deposits are more deeply buried upslope. Along most of the stream channel, features and artifacts are exposed and appear to be lying directly on bedrock or in very thin alluvial/colluvial sediments. These areas indicate a relatively intensive occupation. There is also a ca. 50-m-long stretch of apparently undisturbed, vegetation-covered alluvial terrace in the northem portion of this site. Three shovel tests across this area produced burned sandstone or fire-cracked rock fragments in the upper $20 \mathrm{~cm}$ and at $50 \mathrm{~cm}$. There was no definite natural or cultural stratification, so it is unclear if this represents multiple buried components or a single component buried at different depths.

Artifacts observed in the campsite areas of this site consist of numerous quartzite manos and mano/ hammerstones, a sandstone mano, a sandstone metate fragment, chipped lithic debris, cores, and a few chipped stone tools (bifaces and unifaces). A gouge was collected. No temporally diagnostic artifacts were recovered, but the cultural features and materials at this site are very similar to a nearby site (41GR583) where a late Archaic Marcos dart point was collected.

This site is likely to have a high research potential due to the extensive buried cultural deposits. The areas exposed by erosion only hint at the density and variety of features and artifacts which are likely to remain in situ in the uneroded alluvial deposits. The number and age of components represented by these deposits, however, cannot be fully evaluated with the limited data available. It is recommended that site 
41GR584 be considered of unknown eligibility for listing on the National Register of Historic Places.

\section{GR585}

Site 41GR585 is a Late Prehistoric campsite situated on a gently east-sloping upland margin near the confluence of two streams. The site is less than $400 \mathrm{~m}$ from a major spring, and a small pool of water in the adjacent stream channel may be a minor seep spring. Vegetation consists of a moderate growth of grasses, juniper, mesquite, prickly pear, yucca, and various forbs in the site area and a variety of trees along the stream channel. The site is covered with sandy sediments with only occasional limited exposures of sandstone bedrock peeking through. There are apparently no significant concentrations of Quaternary Lingos gravels at this site, but outcrops are present on nearby sites. The site covers a ca. $200 \times 200-\mathrm{m}$ area and is at an elevation of 2290$2320 \mathrm{ft}$ msl. The adjacent stream channel is at an elevation of $2280 \mathrm{ft}$ msl and is entrenched into the uppermost sandstone bedrock layer.

Cultural materials observed include large numbers of quartzite and sandstone manos and mano/ hammerstones (ca. 30 specimens were noted), numerous chipped lithic tools (large chopper tools, bifaces, unifacial scrapers, and edge-modified flakes), lithic debitage, mussel shell fragments, and several large unmodified sandstone slabs and Potter chert nodules which appear to be out of place (i.e., manuports). There are also scattered fire-cracked Potter chert fragments and few burned sandstone hearths and scatters. The features and artifacts appear to be concentrated into distinct clusters that may represent separate occupation/activity areas. There was no observable patterning to the manuports (such as stone rings), but they also appear to occur within artifact clusters. The cultural materials at this site appear to be surficial or shallowly buried. Two shovel tests yielded burned rocks in the upper $15 \mathrm{~cm}$.

Of particular importance is the variety of highquality, exotic lithic materials at this site and the temporally diagnostic artifacts. Five artifacts were collected; a large bifacially worked Edwards chert core tool (chopper), a fragment of a distinctive alternately beveled knife of Alibates agate, an untyped arrow point fragment of Alibates agate, a triangular biface fragment interpreted as an arrow point preform, and a reworked stemmed dart point fragment that was subsequently reused as a drill.
The latter two specimens are probably made of some variety of nonlocal Cretaceous chert. In addition, the lithic debitage at this site is dominated by highquality Cretaceous cherts, the majority of which are probably nonlocal. Most of the debitage is small tertiary flakes, indicating that the later stages of tool manufacture and maintenance were significant activities. Other chipped lithic materials noted include local Potter chert and quartzites and possibly local silicified wood and silicified caliche (or chalcedony).

All of the cultural materials are tenatively interpreted as representing a surficial and shallowly buried single component, most likely a very late (i.e., Late Prehistoric II) occupation. The dart point was most likely procured from a nearby site (such as 41GR583) and refashioned into a drill. While no stone alignments were defined, there appears to be relatively discrete patterning of the manuports, features, and artifacts that may represent occupation/ activity areas. It is possible that the site represents a Late Prehistoric or Protohistoric tipi encampment affiliated with the Garza Complex, although this interpretation is speculative at present. Site 41GR585 is likely to have a high research potential but cannot be fully evaluated with the limited data available. It is recommended that the site be considered of unknown eligibility for listing on the National Register of Historic Places.

\section{$41 G R 586$}

Site 41 GR586 is a historic ranching period homestead located along the north side of an eastflowing drainage, immediately adjacent to a small spring and within ca. $100 \mathrm{~m}$ of a major spring. It is situated on a gentle south slope and extends from the relatively flat sandy upland down into the exposed sandstone bedrock stream drainage; it covers a ca. $100 \times 100-\mathrm{m}$ area at an elevation of $2260-2280 \mathrm{ft}$ msl. Vegetation consists of grasses, juniper, mesquite, prickly pear, cholla, and various forbs over most of the site area and a dense growth of various trees (including soapberry and hackberry), shrubs, forbs, and grasses in and around the small spring.

The historic homestead complex consists of seven distinct features (Fig. 4). The first of these is a corral complex that is a generally rectangular shape measuring approximately $45 \mathrm{~m}$ east-west by $30 \mathrm{~m}$ north-south. Fences converge on the corral area which has a loading chute at the southwest comer.

Approximately $50 \mathrm{~m}$ southwest of the corrals is 


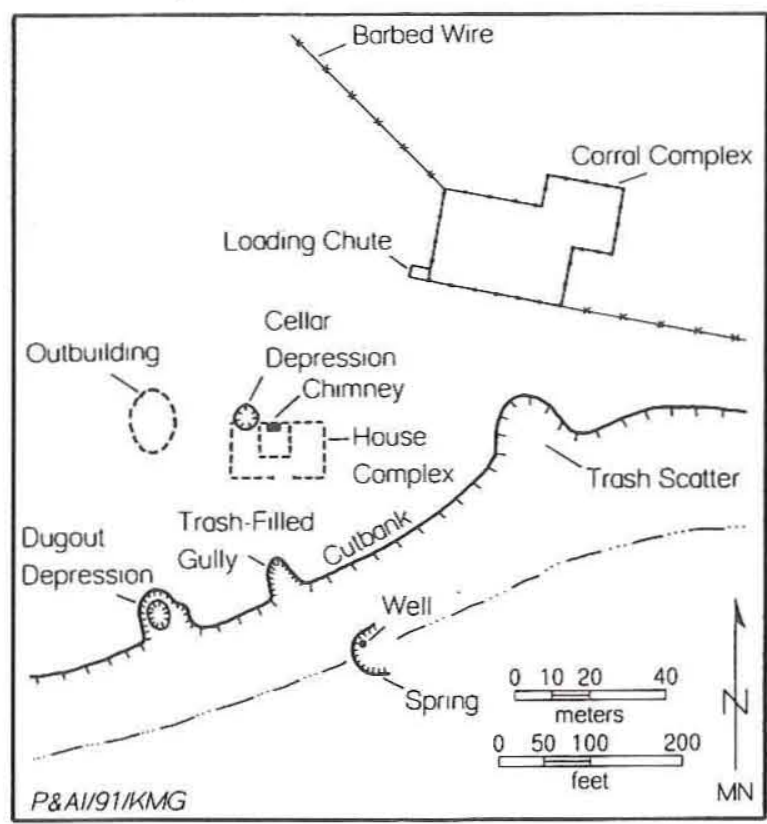

Figure 4. Site map of historic Williams homestead complex, 41GR586.

a partially collapsed stone chimney that marks the former location of the two-room frame Williams home occupied ca. 1904-1915. Stone footings are scattered in the general area on the south side of the chimney, and a depression adjacent to the housesite seems to indicate the former location of a cellar. A yard area is clearly defined by rock alignments. The portion of the yard between the house and the creek to the south is bounded by stones which are placed upright in the earth south of the house in an eastwest-running line. A gap in the upright stones indicates the location of a gate in the yard area and lines up with a third feature that is a trash-filled gully adjacent to the creekbank. Artifacts eroding out of the gully include numerous pieces of pottery, china, metal, and glass.

Immediately south of the gully within a small spring depression in the creekbed is a stone-lined well (Fig. 5) that was excavated approximately $2.3 \mathrm{~m}$ into the ground. A cylindrical stone wall with an exterior diameter of $94 \mathrm{~cm}$ rises approximately $1 \mathrm{~m}$ above the ground surface and is capped by two coarsely worked flat pieces of sandstone. The structure butts up against a rock ledge, and there is water standing in the bottom of the well. Some evidence of exterior plastering is visible on the exterior of the walls. Mortar between the stones is almost entirely intact and appears to be a soft limesand mixture combined with Portland or other cement.

Upstream and west of the well is the fifth site feature, a depression that may indicate the former location of the Williams homestead dugout (19001903). A shallow depression is oriented with its long axis running generally north-south; it measures approximately $2.5 \mathrm{~m}$ wide by $6 \mathrm{~m}$ long. The depression is filled with vegetation, making discernment of artifacts or structural members difficult. One artifact was located within the depression itself, but all other artifacts recorded were located upslope to the northeast approximately $5 \mathrm{~m}$ from the depression.

Approximately $40 \mathrm{~m}$ north and upslope from the dugout site, Feature 6 is marked by scattered milled lumber, nails, and wire that probably indicate the former location of an outbuilding. A final feature is located $60 \mathrm{~m}$ east of the main trash gully and consists of scatters of glass, metal, bricks, and stoneware.

Site History: Site 41GR586 is located on the north side of the Double Mountain Fork of the Brazos River in Survey 70 of Block 5. The property is comprised of approximately 640 acres of school lands that were surveyed for the State of Texas by the Houston and Great Northem Railway Company in 1873. An adjoining section to the north, Survey 71 , was surveyed simultaneously by the railway company for its own use and was held by the company for a number of years (Texas. General Land Office 1873, 1933).

The State of Texas retained ownership of the even-numbered surveys in Block 5 , including number 70 , for almost 20 years. The land did not remain vacant and unused, however, since both the State and the Houston and Great Northern Railway Company executed a number of leases to individual ranchers and cattle companies during the 1880s. The New York and Texas Land Company, Ltd. of New York State, for example, was the successor owner to the Houston and Great Northern Railway Company of its Garza County lands, and in 1882 it executed a 5-year lease of 137 surveys in Blocks 4, 5, and 6 to J. W. Mooar Brothers, Cornelius Brothers, and C. Sloan of Colorado City, Texas (Garza County Deed Record 3: 29-32). In 1890 the State of Texas executed a 3year lease of 24 surveys in Blocks 5 and 6 to A. J. and F. M. Long, owners of the Lexington Ranch Company of Nolan County, Texas (Garza County Deed Record 4:280-282). Three of the State surveys-70, 72, and 78-comprise the bulk of the proposed wildlife mitigation area, and it is assumed 


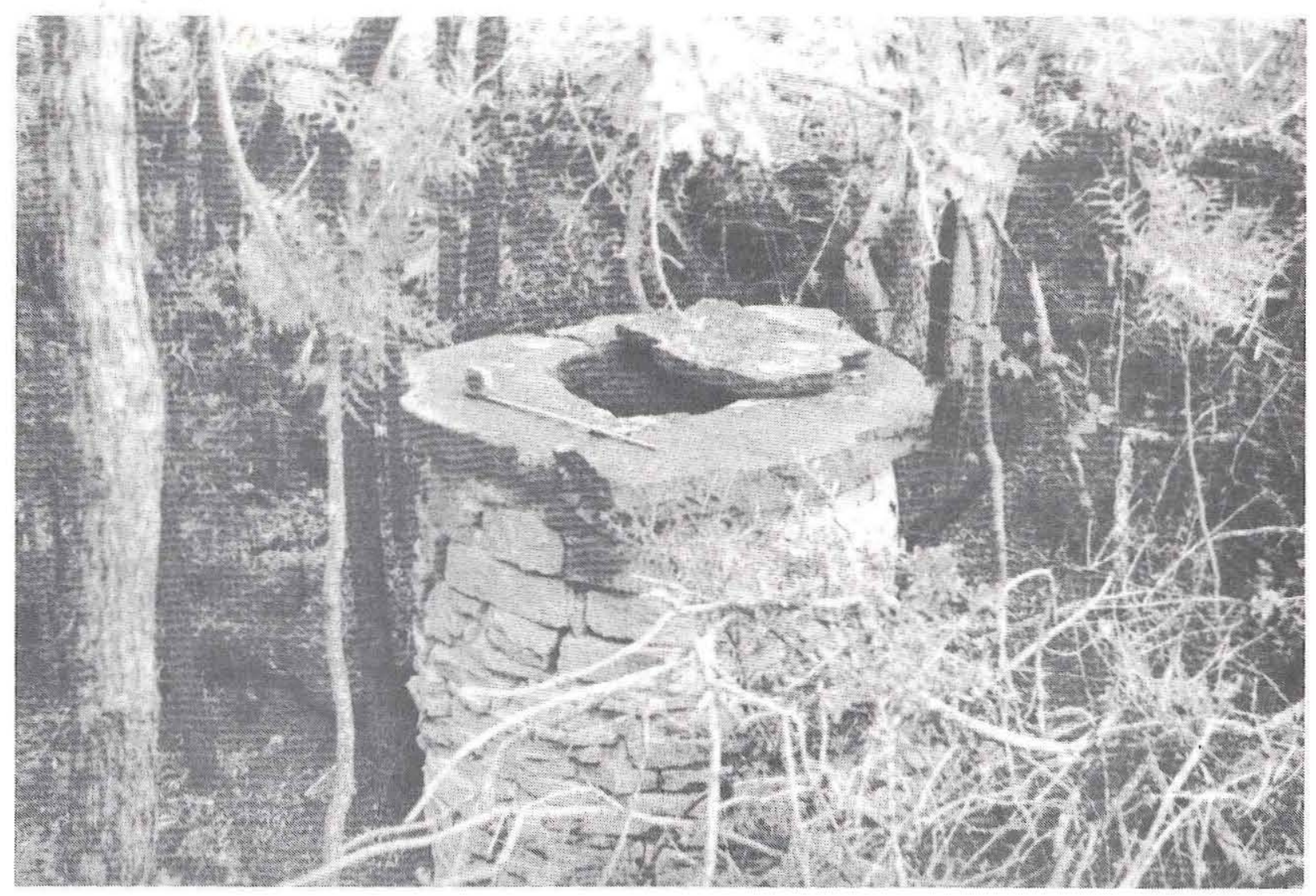

Figure 5. Rock-lined well in small spring, 41GR586.

that those sections together with the surrounding rangeland were utilized by the Longs throughout the 1890s.

Andy and Francis Long were among the most prominent cattlemen along the Double Mountain Fork, where they were responsible not only for developing one of the first ranches in the region but also for hiring numerous young cowboys who eventually formed the backbone of the area's permanent population after 1900. Among those hands was William George Williams, a native of Guadalupe County, Texas, who moved to Garza County in 1893 (The Snyder Daily News, October 16, 1953:1). According to census and county records and the recollections of descendants, Williams was born on January 25, 1876, near Kingsbury, Guadalupe County. His parents were
Z. T. Williams (born ca. 1849 in Georgia to parents from South Carolina) and Mary Smithers (born ca. 1848 in Louisiana to a father from Tennessee and a mother from Louisiana). Williams and Smithers married in Guadalupe County on December 20, 1872. By September 1887, their family consisted of six children: William G. (January 1876), Naomi (April 1878), Richard P. (February 1880), Sarah (October 1882), Thom(as?) G. (May 1885), and Willis C. (September 1887) (Spring and Nowotny n.d.:51; U.S. Bureau of the Census 1880, 1900).

According to a descendant (Headstream 1990), Z. T. Williams died of a fever, and the family decided to move west to join a relative who was employed by the Longs. ${ }^{1}$ W. G. Williams, still a young man, found employment with the Longs as

${ }^{1}$ The relative may have been Christopher Smithers, brother of Mary Smithers Williams, who had business dealings in 1900 with A. J. and F. M. Long (Garza County Deed Record 7:244). 
well, and he worked for the Lexington Ranch Company during the 1890 s, helping with the support of his family.

The passing of the Four-Section Act by the State Legislature on April 4, 1895, was intended to encourage permanent settlement on State lands. Unfortunately for ranchers like the Longs, who had depended on the leasing of these lands for the profitable operation of their ranches, the effect of the Act would be to withdraw property from the public domain. As the 1890 s drew to a close and more potential homesteaders looked to the plains area of West Texas, the Longs took steps to counter the potentially negative effects of the Act. Like many other ranchers in the area, they induced their hands to file on four sections each and then to lease those sections back to the company (Boyd et al. 1989:142).

W. G. Williams apparently decided to assist the Longs in their quest for pastureland, for on February 21, 1900, he filed an application to homestead one section (70) and to purchase an additional two sections for dry grazing (72 and 78) (Texas. General Land Office 1933, 1939a, 1939b). Giving his post office address as Dark (near present-day Dermott), Williams obligated himself to pay $\$ 640.00$ to the State of Texas within 40 years. He also solemnly swore that "I desire to purchase said land for a home; and ... I have in good faith settled thereon, and am now a bona fide settler thereon. .." (Texas. General Land Office 1933).

Sometime within the next 2 months, the Longs approached their employees about leasing their homestead and pasturelands for periods of time ranging from 3 to 10 years. Terms of the leases were generous, obligating the Longs to pay each lessor $\$ 100.00$ rent per year, the amount each lessor owed in interest annually to the State School Fund, and all taxes due. The ranch hands agreed not to sell the land during the first 3 years of the lease without the consent of the lessees. At the end of that time, the lessors gave first right of refusal to the Longs. Finally, after 3 years, each lessor could reserve one section and graze his own stock there (Garza County Deed Record 6:301-359).

Employees of the Lexington Ranch Company who chose to participate included O. B. Kelly, J. S. Boren, Walter Roy, N. P. Pyron, J. M. Boren, S. D.
Boren, and Will Williams (Garza County Deed Record 6:301-359). ${ }^{2}$ In about 1 year, however, the Longs sold their leases to the firm of Clark, Connell and Scharbauer, a ranch company consisting of E. W. Clark, W. E. Connell, and John Scharbauer. That firm then renegotiated the leases. On June 1, 1901, the partners leased Sections 54, 72, and 78, Block 5, from Will Williams for 2 years for which Williams was paid $5 \varnothing$ per acre per annum (Garza County Deed Record 7:21). This lease was followed by one in August 1902 which released Williams from the lease signed with the Longs and provided for the use of the sections by Clark, Connell and Scharbauer (Garza County Deed Record 7:244).

In order to fulfill the terms of his agreement with the State, Williams was obligated to live on Section 70 and to make his home there. According to an affidavit filed on February 28, 1903, Williams swore that he had made his home on Section 70 for a full 3 years and therefore had completed the occupancy requirement (Texas. General Land Office 1933). According to informants (Williams and Ward 1987; Headstream 1990), that home consisted of a dugout located at 41GR586 (see Fig. 4) adjacent to a springfed drainage that ran easterly before flowing into the Double Mountain Fork. The site was well chosen, being adjacent to a reliable source of fresh water, to range suitable for livestock, and to an area of relatively level land that could be cultivated.

Williams lived alone for 3 years, at the end of which he built a two-room frame house upslope from his dugout (see Fig. 4). On December 13, 1903, he married Pearl Justice, daughter of Justiceburg founders Jeff and Mattie Justice, at the Justice Ranch house (The Snyder Daily News, December 2, 1970:1). W. G. and Pearl moved into the house and had their first child, Wayne, born in Snyder on November 11, 1904. According to a descendant (Headstream 1990), the Williamses shared their small home with his mother and two sisters. The building faced south and was heated with a stone fireplace located on the north wall. Footings raised the building above ground level, and access was through a single door in the front facade.

The Williams family worked hard, raising cattle, farming, and saving their money. They prospered sufficiently to acquire additional sections of land,

${ }^{2}$ E. A. Linn and J. W. Smith also leased their land, but it is not known if they were employed by the Longs. 
including Survey 941, Block 97, Houston and Texas Central Railroad Company, and Survey 11, Block 2, Texas and New Orleans Railroad Company (Garza County Deed Record 10:527-529, 541-543). They also had a daughter, Alice, who was born in 1907 (U.S. Bureau of the Census 1910). Their son Wayne attended school in Polar a short distance to the east, where the family took their cotton to be ginned (Headstream 1990).

In 1915, the Williamses bought two sections (67 and 68) on the south side of the Double Mountain Fork from Nonnie and Irene Rodgers (Garza County Deed Record 15:37), and they moved to the new property. A year later, they moved into Snyder so that Wayne could attend high school (Headstream 1990; The Snyder Daily News, October 16, 1953). Will Williams continued to ranch on the Garza County property, where he spent much of his time. He was successful as a rancher and reinvested his profits in land. In 1928 he acquired Section 71 immediately north of the old homestead, thus blocking up the 1,560-acre parcel currently proposed for wildlife mitigation purposes. He also bought more land on the south side of the river, eventually acquiring a total of 13 sections on which he raised Hereford cattle (Scurry County Probate File No. 1512). He found time, in addition, to serve the regional community as a director of the Snyder National Bank (The Snyder Daily News, October 16, 1953). According to a granddaughter (Headstream 1990), Williams was an avid advocate of education, believing that "a teacher was just one step below the Baptist preacher. ..." During the Depression, when schools paid their employees in scrip, he encouraged the Snyder National Bank to buy the scrip, thus making cash available to the teachers. His son Wayne earned two degrees, the first at Hardin-Simmons and the second at the University of Texas where he was a member of the first graduating class in business administration.

W. G. Williams ranched until his death on October 16, 1953, after which his property was inherited by his widow and two children (Scurry County Probate File No. 1512). Eventually, four of the sections, 70,71, 72, and 78, were inherited by his daughter Alice Williams Clark (Scurry County Probate File No. 2782), whose only descendant owns the property today.

Site 41GR586 appears to meet the registration requirements for cattle ranching camps and homesteads established under the region's historical context "Ranching on the Western Rolling Plains, 1877-1945"
(Freeman 1990c:119-123). The site has sufficient integrity of architectural and archeological remains to address many specific research problems; it also shares characteristics with similar property types already assessed as eligible for listing on the National Register of Historic Places (Freeman 1990c:123131). Thus, it is recommended that site 41 GR5 56 be considered eligible for listing on the National Register of Historic Places.

\section{GR587}

Site 41GR587 is an open campsite/lithic procurement area of undefined prehistoric age situated on the upland margin and lower bedrock benches on the west side of a main south-flowing drainage. Quaternary Lingos gravels are exposed along the eroding upland edge and redeposited onto the lower benches. Vegetation consists of grasses, juniper, mesquite, yucca, prickly pear, catclaw acacia, and various forbs. It is relatively sparse on the upland margin and is much more dense below the canyon rim, although eroded areas do provide good surface exposure even on the lower benches. A two-track road runs across the site, ending on a projecting upland nose; ca. $20-30 \mathrm{~cm}$ of upland sediments are exposed by the roadcut. The site extends $200 \mathrm{~m}$ east-west by $400 \mathrm{~m}$ north-south and from an elevation of 2260 to $2320 \mathrm{ft}$ msl.

Cultural materials consist of evidence of lithic procurement of the gravels and evidence of campsite activities that are mainly confined to the upland margin above the canyon rim. The former consists of cores, tested cobbles, and flakes of local quartzites and Potter chert, while the latter includes burned rock features and artifacts. One portion of the upland is deflated with exposed gravels mixed with firecracked Potter chert fragments, thick bifacial and unifacial tools and preforms, and quartzite mano/ hammerstones.

A second and larger area has intact upland sediments and is relatively flat. It is the highest portion of the site and appears to contain intact buried cultural deposits. Two sandstone hearth clusters and associated artifacts (including a flake of nonlocal Tecovas jasper) are exposed in the roadbed in this area. A small angular core of probable nonlocal Cretaceous chert was collected from a depth of $25 \mathrm{~cm}$ in a nearby shovel test, and a fire-cracked Potter chert fragment was found in situ at $30 \mathrm{~cm}$ in a nearby backhoe trench (Profile 8, see Chapter 4 and 
Appendix). The trench revealed $1.9 \mathrm{~m}$ of sandy sediments, becoming increasingly calcareous with depth, above the calcium carbonate-cemented gravels of the Lingos formation. Scattered burned sandstone, fire-cracked Potter chert fragments, and sparse lithic tools and debitage are exposed in this area, but the majority of the cultural materials appear to be buried to at least $30 \mathrm{~cm}$. Artifacts observed include a quartzite core, two quartzite mano/hammerstones, two Potter chert chopper tools, a Potter chert scraper, and a silicified wood utilized flake. In addition, a Tecovas jasper scraper was also noted.

The cultural deposits at this site could represent a single or multiple components. They are temporally undefined due to the lack of diagnostics, but the nature and depth of the buried cultural materials suggest some antiquity, perhaps late Archaic or earlier. The presence of intact buried cultural deposits indicates that the site is likely to have a high research potential, but it cannot be fully evaluated with the limited data available. It is recommended that site 41GR587 be considered of unknown eligibility for listing on the National Register of Historic Places.

\section{GR588}

Site 41GR588 is an open campsite of undefined prehistoric age situated on an east-projecting point of an upland rise, ca. $500 \mathrm{~m}$ west of the canyon rim of the main south-flowing drainage. It is located ca. $300 \mathrm{~m}$ south of a tributary drainage and is less than $1 \mathrm{~km}$ from two major spring complexes. The site area is extremely flat and is covered with short grass and a sparse growth of mesquite, juniper, prickly pear, and agarita. The upland sediments are very thin, and weathered sandstone bedrock is exposed in small (1-to-4-m-diameter) clusters in the site area, but none protrude much above the ground surface. The site covers ca. $35 \times 45 \mathrm{~m}$ at an elevation of $2340 \mathrm{ft}$ msl.

Cultural materials consist of a very sparse scatter of probably burned sandstone, fire-cracked Potter chert fragments, and lithic debris (mostly Potter chert and coarse-grained quartzite). Two quartzite mano fragments are the only tools that were observed. In addition, two partially exposed possible hearth features were noted, but it is difficult to distinguish them from the natural sandstone bedrock exposures. Two negative shovel tests indicated that there is less than $20 \mathrm{~cm}$ of sandy sediment above caliche and weathered bedrock. All of the evidence suggests a relatively short term, ephemeral occupation. The scarcity of cultural materials and lack of significant buried deposits indicate that the site has a low research potential. Site 41GR588 is assessed as not eligible for listing on the National Register of Historic Places.

\section{GR589}

Site 41 GR589 is an open campsite/lithic procurement area of undefined prehistoric age situated entirely within a lower bedrock bench terrace on the west side of the main south-flowing drainage. The bedrock terrace begins just below the canyon rim and slopes eastward down to a second sandstone bedrock ledge immediately above the valley floodplain. The

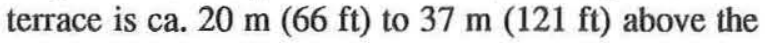
stream channel and extends from $2220-2280 \mathrm{ft} \mathrm{msl}$. Vegetation consists of grasses, juniper, mesquite, yucca, prickly pear, and unusually large amounts of catclaw acacia. The vegetation varies from very dense in some areas to very sparse in eroded areas. Two major gullies bisect the terrace and the site into three east-projecting ridges, designated from north to south as Areas A, B, and D. Quaternary Lingos gravels, probably redeposited from the uplands, are exposed in the eroded portions of the site and on an isolated hill (Area C) on the point of the central projecting ridge. At the eastern edge of the isolated hill, there is a ca. $20-\mathrm{m}(66-\mathrm{ft})$, nearly vertical drop into the valley floodplain.

Cultural materials consist of evidence of lithic procurement (cores, tested cobbles, flakes, and hammerstones) and campsite activities in various parts of the site. Area A contains utilized large Potter chert and quartzite gravels and a relatively dense scatter of lithic debitage along all its eroding edges. A few tools, mainly unifaces and edgemodified flakes, and some possible ground quartzite fragments were also noted. Much of the Potter chert (debitage and tools) appears to have been heat treated. Scattered fire-cracked Potter chert is abundant on the deflated nose of the ridge, and one possible feature (a 1-m-diameter cluster of firecracked rocks) is present. Cultural deposits appear to be buried in this portion of the site, and a shovel test revealed $70 \mathrm{~cm}$ of sediment above a calcareous hard pan and produced a fire-cracked Potter chert fragment at $20-30 \mathrm{~cm}$ below surface.

Area B consists of extensively utilized gravels 
and some isolated scatters of fire-cracked Potter chert. Most of the cultural materials are exposed along the eroded edges of the gullies. Only a few tools (i.e., unifaces and bifaces) were observed. Heavy vegetation growth obscures much of this area which appears to have intact sediments and a considerable potential for buried deposits.

Area $\mathrm{C}$ is the gravel-covered, isolated hill in the east-central portion of the site. Sparse vegetation is found on the hill itself, but it is quite thick around the base of the hill. The hill is roughly circular, ca. 30 to

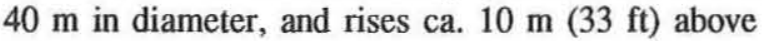
the bedrock bench. Lithic procurement is the main activity represented in this area, but some firecracked Potter chert is exposed around the base of the hill. This area has a low potential for buried cultural deposits.

Area D is the largest of all the site areas and contains isolated exposures of utilized gravels and sporadic concentrations of fire-cracked Potter chert fragments. This area appears to have been less intensively utilized than areas A and B; however, very dense vegetation over most of this area obscures the underlying sandy sediments that probably contain buried cultural deposits. All of the exposed materials are along the eroding edges of the gullies.

This site appears to have a relatively low density of lithic tools but does have burned rock features and potential for extensive buried cultural deposits. Site 41GR589 is likely to have a high research potential but cannot be fully evaluated with the limited data available. Thus, it is recommended that the site be considered of unknown eligibility for listing on the National Register of Historic Places.

\section{$41 G R 590$}

Site 41GR590 is an open campsite of undefined prehistoric age situated in the upland margin on the west side of the main south-flowing drainage. The site is immediately adjacent to the canyon rim and overlooks the lower bedrock benches within a broad segment of the valley. It is just north of a tributary drainage and is ca. $200 \mathrm{~m}$ from a major spring complex. Vegetation consists of grasses, mesquite, juniper, prickly pear, cholla, and catclaw acacia. The site is at an elevation of $2300 \mathrm{ft}$ msl and extends $50 \mathrm{~m}$ east-west by $150 \mathrm{~m}$ north-south.

Cultural materials consist of a sparse scatter of lithic debitage and tools and a very few fragments of fire-cracked Potter chert. The tools include unifaces and bifaces, and two gouges (one unifacial and one bifacial) were collected. Only one feature, a 1-mdiameter cluster of fire-cracked Potter chert fragments, was observed. Most of the site area is deflated, and most of the cultural materials are lying directly on bedrock or in thin pockets of sandy sediment. The sediments thicken upslope, but only sparse cultural materials were observed along the eroded edge of the upland sediments. The site has a very low artifact density and a low potential for intact buried cultural deposits. Site 41GR590 is assessed as not eligible for listing on the National Register of Historic Places.

\section{GR591}

Site 41GR591 is an open campsite/lithic procurement area of undefined prehistoric age situated on an erosional remnant hill on a peninsula that projects northeastward from a lower bedrock bench. The peninsula is ca. $40 \mathrm{~m}$ south of an east-flowing drainage and is less than $200 \mathrm{~m}$ from a major spring. It is located on the west side of the main southflowing drainage near its confluence with the smaller tributary and overlooks the floodplain immediately to

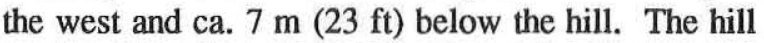
is at an elevation of $2220 \mathrm{ft}$ msl and rises only a few meters above the elevation of the bedrock bench. Sandstone bedrock is exposed in places, and Quaternary Lingos gravels apparently redeposited from the uplands cover the hill. There are only thin pockets of sandy sediment, and the sparse vegetation consists of grasses, juniper, mesquite, yucca, cholla, catclaw acacia, and prickly pear. Surface visibility is very good. The site area is confined to the small hill and covers ca. $30 \times 50 \mathrm{~m}$.

Cultural materials consist of cores, primary and secondary flakes, a quartzite chopper tool, a quartzite mano fragment, a Potter chert unifacial gouge (collected), and some scattered fire-cracked Potter chert. Two features, a large scatter (ca. $2 \mathrm{~m}$ in diameter) and a small cluster (ca. $25 \mathrm{~cm}$ in diameter) of firecracked Potter chert, were observed. All of the lithic materials are of local quartzites or Potter chert, and some of the Potter chert debitage appears to have been heat treated. The site area is heavily eroded, and all of the cultural materials are surficial, although there is a low potential for minimal, shallowly buried cultural deposits upslope. Site 41GR591 is considered to have a low research potential and is assessed as not eligible for listing on the National Register of 
Historic Places.

\section{$41 G R 592$}

Site $41 \mathrm{GR} 592$ is an open campsite/lithic procurement area of undefined prehistoric age. It is situated along the north-sloping upland margin south of an east-flowing drainage and less than $100 \mathrm{~m}$ from a major spring complex. Sandstone bedrock is exposed along the canyon rim and over much of the site area, and Quaternary Lingos gravels are present but not abundant. Sandy sediments are present in thin pockets and thicken upslope. Vegetation is absent or sparse along the eroded canyon rim but becomes quite dense upslope. It consists of grasses, juniper, mesquite, prickly pear, yucca, and various forbs. The site extends $150 \mathrm{~m}$ northeast-southwest by $450 \mathrm{~m}$ northwest-southeast at an elevation of $2260-2300 \mathrm{ft}$ msl.

Cultural materials include minimal evidence of lithic procurement (cores, tested cobbles, and flakes) over the entire site area. Evidence of campsite activities includes two isolated bedrock mortars (over $200 \mathrm{~m}$ apart), a single feature (a 2-m-diameter cluster of fire-cracked Potter chert), and very sparse scattered fire-cracked Potter chert fragments. No tools were noted, and there is a relatively low density of artifacts. Most of the site area is heavily eroded, and all of the cultural materials appear to be surficial, although there is a low probability for minimal, shallowly buried cultural deposits upslope. Site 41GR592 is considered to have a low research potential and is assessed as not eligible for listing on the National Register of Historic Places.

\section{$41 G R 593$}

Site 41 GR593 is an open campsite of undefined prehistoric age situated on an upland rise over $200 \mathrm{~m}$ from the nearest ephemeral drainage and ca. $700 \mathrm{~m}$ from a major spring complex. The site covers ca. $100 \times 100 \mathrm{~m}$ at an elevation of $2340 \mathrm{ft} \mathrm{msl}$ and is only a small part of a much larger upland rise. It is located ca. $1 \mathrm{~km}$ west of the main south-flowing drainage and is on the eastern side of the rise. Most of the site area is flat, and vegetation is limited to a sparse growth of grasses and small forbs. Surface visibility is excellent. Just east of the site, the rise begins to drop, sloping gently eastward, and mesquite trees and prickly pear become abundant (see Fig. 2b). The only break in the flat topography of the site area is an occasional isolated outcrop of sandstone bedrock extending a few centimeters above the ground surface. Undoubtedly, sandstone bedrock is very shallowly buried under the entire site area, and these thin sediments account for the lack of mesquite trees.

Cultural materials are surficial or shallowly buried, probably in the upper $10 \mathrm{~cm}$ only. Shovel probes revealed thin sediments (ca. $20 \mathrm{~cm}$ in most places), and a shovel test revealed a maximum of ca. $40 \mathrm{~cm}$ of sediment, becoming increasingly calcareous, above the bedrock. Due to the unusual nature and setting of this site and its small size and lack of vegetation, all cultural materials were mapped and described. A light scatter of possibly burned sandstone fragments, fire-cracked Potter chert fragments, lithic debitage, a few chipped stone tools, and a single quartzite mano were observed. Seventy-two surface artifacts (includes fire-cracked Potter chert fragments) were recorded. Chipped stone tools consist of edge-modified flakes, chopper tools, and unifacial scrapers, and the lithic debitage is dominantly small tertiary flakes of Potter chert and chert. All of the lithic materials appear to be local quartzites, Potter chert, and chert.

No definite features were observed, although a possible hearth was partially exposed. It is difficult to distinguish between the bedrock outcrops and cultural features and to identify the burned from the unburned sandstone. A number of isolated sandstone slabs did appear to be out of place (i.e., manuports), but no patterning (such as rock rings) could be discerned. There is no apparent patterning to the artifacts, but they all definitely cluster in and around the sparse sandstone outcrops. Since this is the only outcrop of sandstone in the upland for hundreds of meters, it appears that the occupants intentionally selected this locality specifically because of the presence of sandstone.

Because of the sparse surficial nature of the cultural materials and its upland setting and distance from water, it is speculated that this site represents a very short term occupation that is relatively late in time (i.e., Late Prehistoric or Protohistoric). This speculation, however, cannot be supported by conclusive data. Regardless, the site has a very limited potential for shallowly buried cultural deposits, and the current investigation appears to have exhausted much of the site's research potential. Given the paucity of cultural materials and lack of diagnostic artifacts or otherwise datable materials, site 41 GR593 has a low research potential and is 
assessed as not eligible for listing on the National Register of Historic Places.

\section{GR594}

Site 41GR594 is a lithic procurement area of undefined prehistoric age situated along the upland margin on the north side of an east-flowing tributary. It is ca. $300 \mathrm{~m}$ from a major spring complex and covers a $50 \times 150-\mathrm{m}$ area at an elevation of 2240 $2270 \mathrm{ft}$ msl along the canyon rim. Vegetation consists of grasses, juniper, mesquite, cholla, prickly pear, catclaw acacia, yucca, and various forbs. Quaternary Lingos gravels are exposed all along the canyon rim.

Cultural materials consist of very sparse cores, tested cobbles, flakes, and a few crude bifaces (probably preforms) and unifaces. No features or fire-cracked rocks were observed. The cultural materials are confined to the gravel exposures, and all of the lithic artifacts are of local materials. This site has a low potential for intact buried deposits and appears to represent a minimally utilized lithic source area. Site 41GR594 is assessed as not eligible for listing on the National Register of Historic Places.

\section{GR595}

Site 41 GR595 is a lithic procurement area of undefined prehistoric age situated on an eroded upland margin on the west side of the main southflowing drainage. It is ca. $0.6 \mathrm{~km}$ from the nearest spring. Sporadic but dense outcrops of Quaternary Lingos gravels are exposed along the canyon rim. There is a near-vertical drop beyond the canyon rim, and the site overlooks the valley floodplain ca. $25 \mathrm{~m}$ $(82 \mathrm{ft})$ below. Vegetation is sparse and consists of grasses, juniper, mesquite, prickly pear, cholla, catclaw acacia, and various forbs. The site covers $150 \mathrm{~m}$ east-west by $400 \mathrm{~m}$ north-south and extends from 2220 to $2270 \mathrm{ft}$ msl.

Cultural materials consist of evidence of lithic procurement where dense concentrations of gravels are exposed. Cores, tested cobbles, and flakes of Potter chert and quartzite were observed. It appears that there was moderate to intensive use of the gravels, and an unusually high frequency of maroon (or purple) Ogallala quartzite was observed at this site. No features or scattered burned rocks were observed, and the only formal tools are two gouges (one bifacial, one unifacial) that were collected.
There is little or no potential for buried cultural deposits. Site 41GR595 has a low research potential and is assessed as not eligible for listing on the National Register of Historic Places.

\section{GR596}

Site 41GR596 is an open campsite/lithic procurement area of undefined prehistoric age situated in the upland margin at the head of a small drainage (ca. $200 \mathrm{~m}$ in length) on the north side of an eastflowing tributary. The small drainage forms a box canyon in the valley below the site, which is ca. $75 \mathrm{~m}$ north of the main tribuary. A major spring complex is located ca. $400 \mathrm{~m}$ away. Sporadic outcrops of Quaternary Lingos gravels are exposed around the small drainage at the head of the box canyon and along the canyon rim. The ephemeral drainage bisects the site and provides good erosional exposure. It heads in the upland at the northern end of the site where extensive sheet erosion has occurred. Vegetation is sparse in the site area and consists of grasses, mesquite, juniper, yucca, prickly pear, cholla, Mormon tea, and various forbs. The site area is ca. $100 \times 150 \mathrm{~m}$ at an elevation of $2240-2280 \mathrm{ft} \mathrm{msl}$.

Cultural materials include evidence of very minimal lithic procurement; a few cores, tested cobbles, and flakes were observed in the gravel outcrops. The campsite component is also ephemeral and consists of two burned rock features, a Potter chert chopper, and a few tertiary chert flakes. These materials are exposed in the upper (northern) portion of the site where cutbank and sheet erosion have exposed a considerable area. One feature is a small (ca. 2-m-diameter) scatter of fire-cracked Potter chert fragments with no other cultural materials associated. The second feature is a small (ca. 1-mdiameter) but dense cluster of fire-cracked Potter chert fragments. It consists of ca. 15 large (fistsized) cobble fragments and numerous small fragments. The chopper tool and flakes were found in close proximity to this feature.

In spite of the excellent erosional exposure over a ca. $30 \times 30-\mathrm{m}$ area adjacent to the features, no other features or artifacts were observed, and the two recorded features have been slightly displaced by sheet erosion. These features appear to represent an ephemeral campsite which has a low potential for intact buried cultural deposits. Site 41GR596 is assessed as not eligible for listing on the National Register of Historic Places. 


\section{GR597}

Site 41GR597 is an open campsite of undefined prehistoric age situated on an upland rise ca. $200 \mathrm{~m}$ from an upland ephemeral drainage and ca. $600 \mathrm{~m}$ from a major spring complex. The site area is very flat and is located on the southeastern edge of a prominent south-projecting upland rise. The rise drops off just beyond the site and slopes gently southeastward toward the ephemeral drainage. Vegetation is sparse to moderate and consists of grasses, prickly pear, cholla, and a few small mesquite trees. The vegetation becomes quite dense toward the drainage and the mesquite trees are much larger. The site area is estimated to be ca. $40 \times 40 \mathrm{~m}$ at an elevation of $2320 \mathrm{ft} \mathrm{msl}$.

Surface cultural materials observed consist of six pieces of debitage (four chert, one quartzite, and one silicified caliche) and five fragments of fire-cracked Potter chert. It appeared that these materials were brought to the surface by plant/animal disturbances and that the site had a potential for buried cultural materials. Two shovel tests and a backhoe trench (Profile 10, see Chapter 4 and Appendix) were excavated to assess this potential. The backhoe trench and one shovel test yielded no cultural evidence, but the second shovel test produced a tertiary chert flake (collected) at ca. $40 \mathrm{~cm}$ below the surface. The backhoe trench revealed ca. $75 \mathrm{~cm}$ of sandy loam and loam above calcium carbonate-cemented Lingos formation gravels. The upper sediments, however, exhibited very little stratification. While this site does have a potential for buried cultural remains, the paucity of materials indicates that it has a low research potential. Site 41GR597 is assessed as not eligible for listing on the National Register of Historic Places.

\section{$41 G R 598$}

Site 41GR598 is an open campsite of undefined prehistoric age situated on an upland rise located ca. $100 \mathrm{~m}$ southwest of an ephemeral upland drainage. The site occupies a small (ca. 50x100-m) ovalshaped ridge at an elevation of $2315 \mathrm{ft} \mathrm{msl}$. It rises only a meter or two above the surrounding upland, which slopes generally northeastward toward the drainage. This subtle feature appears to be a ridge of sandstone bedrock that is covered by a thin veneer of sandy sediment. Weathered sandstone bedrock crops out in isolated clusters on the rise. It is devoid of large vegetation, undoubtedly because of the thin soils. The site area is covered with grass and small shrubs, but mesquite, prickly pear, cholla, yucca, and catclaw acacia are found around the perimeter of the ridge. A two-track road crosses the southern end of the ridge, and a deeply $(\mathrm{ca} .30 \mathrm{~cm}$ ) bladed roadcut extends along the northern end of the ridge. The latter exposes a large area of sandstone bedrock.

Cultural materials observed on the surface of the ridge and in the bladed roadcut include ca. 35 fragments of fire-cracked Potter chert, a fragment of fire-cracked quartzite, a tested quartzite cobble, and ca. 5 pieces of debitage of local chert and quartzite. The only tools observed were two quartzite manos. No features were observed. Most of the artifacts are exposed in the roadcut, indicating that some cultural materials are shallowly buried. A backhoe trench (Profile 2, see Chapter 4 and Appendix) was excavated in the northern end of the ridgecrest near the roadcut. No cultural materials were recovered, and the trench revealed ca. $60 \mathrm{~cm}$ of sandy loam above a calcareous gravelly zone of weathered bedrock.

Even though there is a potential for shallowly buried cultural deposits, the roadcut and backhoe trench suggest that they would be rather sparse. Due to the paucity of cultural materials, this site is considered to have a low research potential. Site 41GR598 is assessed as not eligible for listing on the National Register of Historic Places.

\section{GR599}

Site 41GR599 is an Archaic (undefined) open campsite situated in the upland margin on the south side of an east-flowing drainage. It extends $300 \mathrm{~m}$ east-west along the upland edge by ca. $100 \mathrm{~m}$ northsouth from the canyon rim back into the sloping upland. The site is at an elevation of 2240-2280 ft $\mathrm{msl}$ and is immediately adjacent to the stream channel and above a major spring complex. Vegetation consists of grasses, mesquite, juniper, agarita, cholla, prickly pear, catclaw acacia, and various forbs; it is sparse in the lower, eroded portion of the site but increases upslope.

The site is divided into several areas by gully erosion, and cultural materials occur all along the gully margin and the eroded lower slope where a sandstone ledge is exposed along the stream channel. Burned rock features and associated artifacts are exposed in several areas of the site, and there obviously are intact buried cultural deposits between gully 
exposures. Twelve distinct features were observed in two main areas in the western portion of the site. They are all small $(<1-\mathrm{m}$-diameter) clusters of burned sandstone (i.e., hearths), but some scattered fire-cracked Potter chert is present over most of the site. The eastern portion of the site is less eroded; hence, no distinct burned rock features were observed. In addition, a single bedrock mortar was found in the eastern area, and there are likely to be others which are buried by sediment.

The artifacts observed tend to be clustered near the exposed hearths but were also noted in one eroded area where no features were observed, possibly indicating that horizontally discrete activity areas are present. Occasionally, artifacts also were found on the surface of the uneroded areas, probably brought to the surface by bioturbation, and indicate that buried cultural deposits exist over a large area. Artifacts observed include a dart point tip (collected), a small gougelike uniface (collected), a sandstone mano, several Potter chert unifacial scrapers or gouges, and a large Potter chert chopper. Lithic debitage observed consisted of flakes of Potter chert, quartzite, and chert, but no obviously nonlocal materials were noted.

The exposed features and artifacts appear to represent a large single-component occupation, and the dart point tip indicates that it is Archaic in age. In addition, the cultural evidence is similar to that observed at other probable Archaic sites (i.e., 41GR583 and 41GR600). The presence of extensive buried cultural deposits indicates a high research potential, but the site cannot be fully evaluated with the limited data available. It is recommended that site 41GR599 be considered of unknown eligibility for listing on the National Register of Historic Places.

\section{GR600}

Site 41 GR600 is a late Archaic open campsite/lithic procurement area situated in the upland margin along the north side of an east-flowing stream at an elevation of $2240-2280 \mathrm{ft} \mathrm{msl}$. It extends $200 \mathrm{~m}$ east-west by $100 \mathrm{~m}$ north-south, downslope into the stream channel adjacent to a major spring complex. Quaternary Lingos gravels are exposed in the eastern end of the site, and sandstone bedrock is exposed by extensive gully erosion in the central portion of the site. Vegetation is moderate to dense in the uneroded areas and consists of grasses, mes- quite, juniper, prickly pear, cholla, and various forbs. A wide variety of vegetation is found along the stream channel and near the spring; hackberry, cottonwood, wild grape, Mexican buckeye, soapberry, and many unidentified plants were noted.

The site is divided into three main areas. The eastern portion consists of a meager gravel outcrop and sparse evidence of lithic procurement (cores, tested cobbles, and flakes). The western portion is a large (ca. 50x50-m) area of intact sandy sediments that extend down to the stream channel. This area is covered with vegetation, but the limited erosional exposure along the stream channel does reveal some cultural materials, mainly burned sandstone and lithic debitage. A Potter chert chopper and occasional flakes on the surface also indicate that buried cultural deposits are present in this area. The western portion of the site is likely to contain the same kinds of cultural materials as are exposed in the central area.

The central portion of the site consists of intact upland sediments that are partially exposed by headward gully erosion. An extremely dense buried cultural deposit (Fig. 6) is revealed in a ca. 1-mhigh vertical cutbank. The top of the ca. $20-\mathrm{cm}-$ thick horizontal cultural zone varies from $0-20 \mathrm{~cm}$ below the ground surface. Sheet erosion immediately above the cutbank exposes a ca. $20-\mathrm{m}^{2}$ area that is literally a pavement of burned sandstone and lithic artifacts. As the sediments thicken upslope to the north, the cultural zone becomes buried. A few surface artifacts were observed up to $60 \mathrm{~m}$ north of the eroded area, and animal burrows ca. 20 and $40 \mathrm{~m}$ north of the cutbank have brought cultural materials to the surface. Hence, it appears that a relatively dense, intact buried cultural zone is present in a ca. $30 \times 60-m$ area. It may be covered by as much as $30-50 \mathrm{~cm}$ of sediment in the northem portion of the site. A geomorphic profile (see Chapter 4 and Appendix) of the erosional cutbank suggests that this buried component is in primary context, and it appears to represent a single-component intensive occupation. Two bedrock mortars found on isolated sandstone remnants near the spring complex also indicate an intensive occupation.

The surface materials undoubtedly represent numerous burned rock features (hearths) and associated activity areas that have been disturbed during the process of erosion. A few discrete hearths were observed in the eroded portion. Cultural materials have also washed down into the exposed bedrock streambed. 


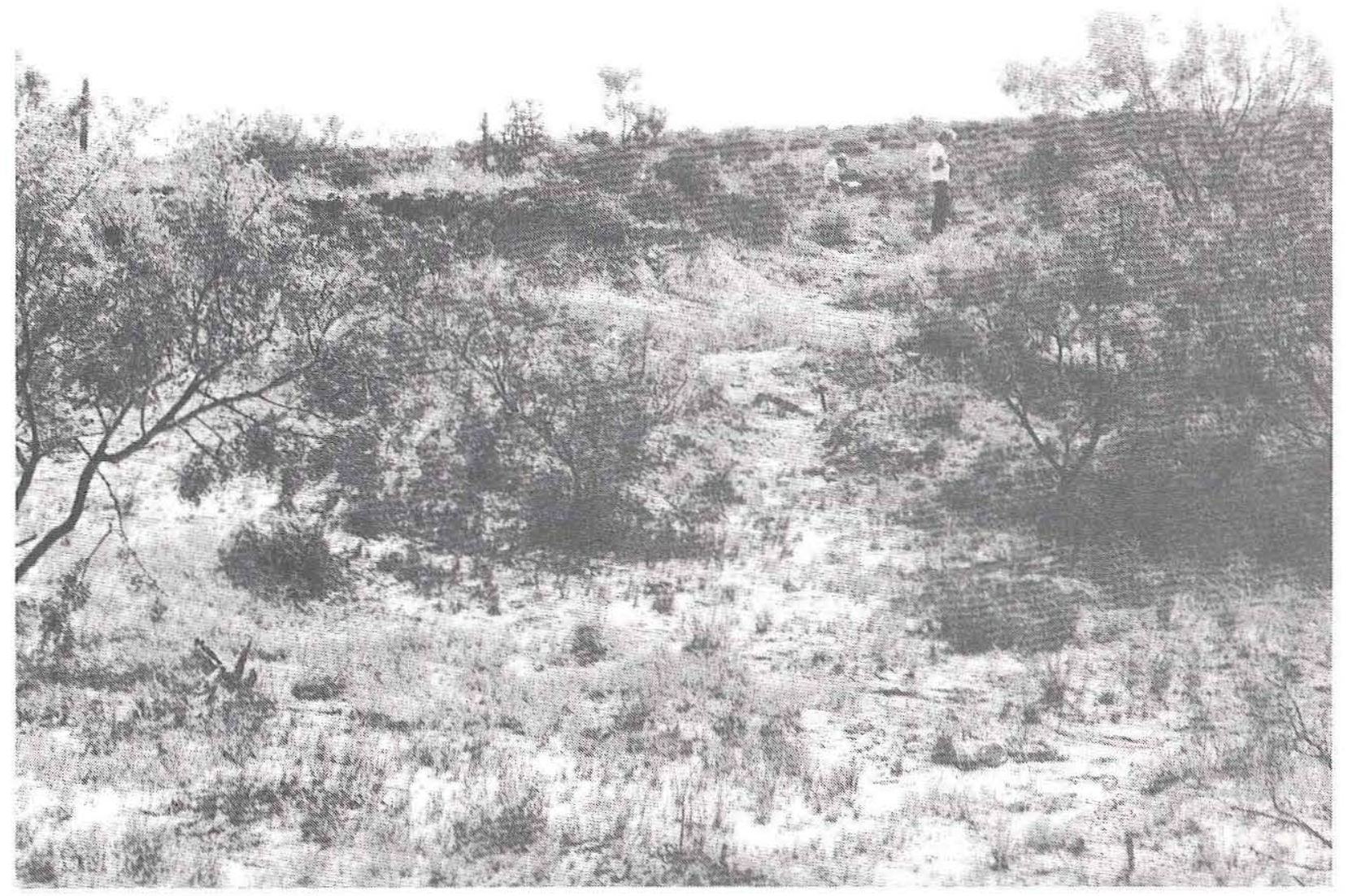

Figure 6. General view of headward gully erosion in the central portion of site 41GR600. In situ cultural materials are exposed in the cutbank in upper center/upper left.

A wide variety of cultural materials occur in the central area. Bone and mussel shell fragments were observed in situ in the cutbank exposure, indicating relatively good faunal preservation. A Marcos dart point fragment was collected, suggesting a late Archaic affiliation for this component. Other artifacts noted include ca. 20 quartzite and sandstone manos, and numerous bifaces, unifaces (scrapers), and edgemodified flakes. Hammerstones, cores, and hundreds of flakes indicate that lithic reduction and tool manufacture were important activities. The lithic debitage is dominated by tertiary flakes of all sizes and includes local materials (i.e., quartzites, Potter chert, and miscellaneous cherts) and a relatively high percentage of nonlocal materials. The nonlocal materials noted are high-quality Edwards chert, Tecovas jasper, and other unidentified lithic types.

Site 41GR600 contains an extensive buried cultural zone that is interpreted as a single- component late Archaic occupation in a primary archeological context. It is likely to have an extremely high research potential, but subsurface testing would be needed to confirm this. Lacking a complete evaluation supported by testing data, it is recommended that the site be considered of unknown eligibility for listing on the National Register of Historic Places.

\section{GR601}

Site 41GR601 is an open campsite of undefined prehistoric age situated on an upland rise ca. $600 \mathrm{~m}$ from the nearest upland drainage and over $1.5 \mathrm{~km}$ from the nearest major spring complex. The site area is flat but slopes gently northward. Vegetation cover is sparse and consists of grasses, prickly pear, yucca, and various forbs. The entire site area has been disturbed by root plowing, and the undulating ground 
surface exhibits furrows as deep as $35 \mathrm{~cm}$. Patchy sandstone bedrock is exposed, indicating that the upland rise is a bedrock ridge covered by thin sediments. The site area is ca. $45 \times 90 \mathrm{~m}$ at an elevation of $2370 \mathrm{ft} \mathrm{msl}$.

Cultural materials observed consist of ca. 25 items: a quartzite core, quartzite and chert flakes, and fire-cracked Potter chert fragments. A backhoe trench (Profile 11, see Chapter 4 and Appendix) was excavated in the site area. No cultural materials were observed, and the sandy sediments were totally disturbed to a depth of ca. $40 \mathrm{~cm}$. This site is interpreted as an ephemeral, surficial occupation and appears similar to other sites located on upland rises (e.g., 41GR602 and 41GR603). The horizontal and vertical contexts of the cultural materials have been totally destroyed by root plowing, and the site has no research potential. Site 41GR601 is assessed as not eligible for listing on the National Register of Historic Places.

\section{GR602}

Site 41GR602 is a Late Prehistoric open campsite situated on an upland rise ca. $700 \mathrm{~m}$ from the nearest upland drainage and ca. $1.5 \mathrm{~km}$ from the nearest major spring complex. The $75 \times 75-m$ site area is relatively flat at an elevation of $2370 \mathrm{ft} \mathrm{msl}$. Vegetation cover is sparse and consists of grasses, prickly pear, cholla, and yucca. The entire site area has been root plowed, and the ground surface undulates considerably with alternating ridges and furrows.

Cultural materials consist of a Washita arrow point (collected) and 11 other artifacts. The latter are fire-cracked Potter chert fragments, a quartzite core, and flakes of local quartzite, Potter chert, and silicified wood, and nonlocal Edwards chert. This site is interpreted as an ephemeral surficial occupation similar to other sites located on upland rises (e.g., site 41GR601 and 41GR603). Although the site yielded a Late Prehistoric arrow point, the context and integrity of the cultural materials have been totally disturbed by root plowing. Site 41 GR602 has no research potential and is assessed as not eligible for listing on the National Register of Historic Places.

\section{$41 G R 603$}

Site 41GR603 is an open campsite of undefined prehistoric age situated on an upland rise ca. $800 \mathrm{~m}$ from the nearest upland drainage and ca. $2 \mathrm{~km}$ from the nearest major spring complex. The $120 \times 120-\mathrm{m}$ site is at an elevation of $2380 \mathrm{ft} \mathrm{msl}$ on a high hill which slopes gently in all directions. The entire site has been disturbed by root plowing, and the ground surface undulates considerably. Patchy sandstone outcrops are exposed, indicating the thin nature of the upland sediments. Vegetation consists of grasses, prickly pear, yucca, cholla, and a few small mesquite trees along the lower slopes.

Cultural materials observed consist of ca. 80 items, over half of which are fire-cracked Potter chert fragments. Other artifacts include a Potter chert gouge (collected), a quartzite mano/hammerstone, a Potter chert chopper tool, an edge-modified flake, and a large sandstone metate fragment. Lithic debitage includes flakes of local materials (i.e., cherts, quartzites, and Potter chert) and nonlocal Edwards chert. A fragment of fire-cracked Potter chert was found in the fill from a backhoe trench (Profile 12, see Chapter 4 and Appendix) excavated in the site area. It came from the upper $40 \mathrm{~cm}$ of disturbed sediment. This site is interpreted as an ephemeral, surficial occupation similar to other sites located on upland rises (e.g., 41GR601 and 41GR602). The context and integrity of this site's cultural materials, however, have been totally destroyed by root plowing. Site 41GR603 has no research potential and is assessed as not eligible for listing on the National Register of Historic Places.

\section{Prehistoric Artifacts}

The policy during the wildlife mitigation survey was to collect the minimum quantity of cultural materials as was necessary to support site interpretations and assessments. Most artifact types were simply recorded in the field. Potentially time-diagnostic or unusual cultural materials were collected from the surface; these were limited to projectile points, gouges, and a few other formal tools. All artifacts discovered during subsurface testing (i.e., backhoe trenches and shovel tests) were collected; these included lithic artifacts or debitage but not burned or fire-cracked rocks.

Twenty-seven artifacts were collected during the survey (Table 3). The classification categories are consistent with those used during the previous Justiceburg Reservoir investigations (Boyd et al. 1989: Appendix I; Boyd, Abbott et al. 1990:Appendix D). Two specimens, a gouge and a hammerstone, were 


\begin{tabular}{|l|l|c|}
\hline \multicolumn{3}{|c|}{ TABLE 3 } \\
SUMMARY OF COLLECTED ARTIFACTS \\
\hline Classification & Description & $\begin{array}{c}\text { No. of } \\
\text { Specimens }\end{array}$ \\
\hline Bifacial & Dart points & 4 \\
Tools & Arrow points & 2 \\
& Arrow point preform & 1 \\
& Beveled knife fragment & 1 \\
& Bifacial gouges & 2 \\
\hline Unifacial & Gouges & \\
Tools & Triangular & 6 \\
& Rectangular & 2 \\
& Irregular & 2 \\
& Miscellaneous scrapers & 3 \\
\hline Other & Cobble tool & 1 \\
Artifacts & Hammerstone & 1 \\
& Core & $1 *$ \\
& Debitage & 27 \\
\hline TOTAL: & & \\
\hline *Recovered from & shovel tests; all others are from \\
the surface. & & \\
\hline
\end{tabular}

collected as isolated finds; all others were recovered from 15 prehistoric sites. Two of these specimens are from shovel tests. Finally, a sample of faunal remains was recovered from site 41GR575; these materials are discussed earlier in this chapter under the site description.

\section{Bifacial Tools}

\section{DART POINTS}

Four specimens are identified as dart points. Two are typed as Marcos, and the other two are untypable. Measurements are presented in Table 4.

Specimen 1 (Fig. 7a) is a complete cornernotched dart point from 41GR583 typed as Marcos (Suhm and Jelks 1962:209; Turner and Hester 1985:117-118). It has an expanding stem, a rounded convex base, and short barbs. The material is a light gray or pale white chert with white flecks, most likely some variety of Cretaceous chert that may be of nonlocal origin. It is slightly asymmetrical as if the blades have been reworked.

Specimen 2 (Fig. 7b) is a proximal fragment of a Marcos dart point (Suhm and Jelks 1962:209; Turner and Hester 1985:117-118) from 41GR600. The distal end and one entire lateral edge are missing. It has an expanding stem with a straight to slightly convex base and a weak barb. The intact blade edge appears to have unifacial retouch, suggesting that it was reused as a scraping or cutting tool after it was broken. The material is light pinkish gray chert with red and white speckles that may be some variety of Cretaceous chert; it is possibly heat treated.

Specimen 3 (Fig. 7c) is an untyped dart point from 41GR585. It has pronounced shoulders, a slightly expanding stem with lightly smoothed lateral edges, and a concave notch in the center of the base. The specimen appears to have been reworked since the stem is very large relative to the blade. The basal notch almost gives the stem a "fishtail" look resembling that of the Martindale type (Suhm and Jelks 1962:213; Turner and Hester 1985:120-121). The specimen also appears to have been used as a drill after it was reworked, as indicated by two notches on alternating edges near the distal end of the point and slight use-wear on the tip. The material is gray Cretaceous chert with a light gray/white patina, possibly of nonlocal origin.

Specimen 4 is an untyped dart point distal fragment from 41GR599. The material is light brown chert of unknown origin but may be some variety of Cretaceous chert. The fragment is $7 \mathrm{~mm}$ thick.

\section{ARROW POINTS}

Three specimens are classified as arrow points (see Table 4 for measurements). One is typed as Washita, one is untyped, and the third is considered to be an arrow point preform.

Specimen 1 (Fig. 7d) is a side-notched Washita (Turner and Hester 1985:195) arrow point from 41GR602. The distal end and one comer of the stem are missing, probably due to pressure snap fractures; isolated nicks are present along the blade edges. These attributes are characteristic postdepositional breaks similar to that described as plow damage by Mallouf (1981:22, 52). The arrow point was manufactured on a thin blade, and one side of the specimen exhibits a remnant ventral surface. The material is a fine-quality gray Cretaceous chert of probably nonlocal origin. It is most likely some variety of Central Texas Edwards chert. 


\begin{tabular}{|c|c|c|c|c|c|c|c|c|}
\hline \multicolumn{9}{|c|}{$\begin{array}{c}\text { TABLE } 4 \\
\text { METRIC DATA FOR PROJECTILE POINTS* }\end{array}$} \\
\hline Type & Site No. & Thickness & $\begin{array}{l}\text { Total } \\
\text { Length }\end{array}$ & $\begin{array}{l}\text { Maximum } \\
\text { Blade Width }\end{array}$ & $\begin{array}{l}\text { Base } \\
\text { Width }\end{array}$ & $\begin{array}{l}\text { Haft } \\
\text { Length }\end{array}$ & $\begin{array}{l}\text { Neck } \\
\text { Width }\end{array}$ & $\begin{array}{l}\text { Base } \\
\text { Depth }\end{array}$ \\
\hline \multicolumn{9}{|l|}{ Dart Points } \\
\hline Marcos & & & & & & & & \\
\hline Specimen 1 & 41GR513 & 9 & 58 & 29 & 20 & 19 & 13 & -5 \\
\hline Specimen 2 & 41GR600 & 5 & $\mathrm{x}$ & $30^{*}$ & 21 & 12 & 15 & -2 \\
\hline \multicolumn{9}{|l|}{ Untyped } \\
\hline Specimen 3 & 41GR585 & 6 & 34 & 29 & 21 & 12 & 18 & +2 \\
\hline Specimen 4 & 41GR599 & $8^{*}$ & $\mathrm{x}$ & $\mathrm{x}$ & $\mathrm{x}$ & $\mathrm{x}$ & $\mathrm{x}$ & $\mathrm{x}$ \\
\hline \multicolumn{9}{|l|}{ Arrow Points } \\
\hline Washita & 41GR602 & 3 & $37 *$ & 13 & 15 & 10 & 8 & +3 \\
\hline Untyped & 41GR585 & 3 & $\mathrm{x}$ & 15 & $\mathrm{x}$ & $\mathrm{x}$ & 5 & $\mathrm{x}$ \\
\hline Preform & 41GR585 & 6 & $\mathrm{x}$ & $\mathrm{x}$ & 22 & $\mathrm{x}$ & $\mathrm{x}$ & $\mathrm{x}$ \\
\hline
\end{tabular}

Specimen 2 (Fig. 7e) is an untyped arrow point fragment from 41GR585. A small portion of the distal tip is broken off and the stem is missing, apparently snapped off at the haft. The proximal two-thirds of the blade edges are serrated, and the point appears to be comer or basal notched. The material is red and white mottled Alibates agate.

Specimen 3 (Fig. 7f) is a proximal fragment of a small thin triangular biface from 41GR585. It is interpreted as an arrow point preform and has a straight base and straight blade edges. The distal end appears to have been snapped off, and some crushing along one edge suggests that it is a postdepositional break. The material is light gray Cretaceous chert of possible nonlocal origin.

\section{BEVELED KNIFE}

A single specimen from 41GR585 is a fragment of an alternately beveled knife (Fig. 7g), a diagnostic tool associated with Late Prehistoric Plains bison hunting. This tool type derives its distinctive alternately beveled blades from repeated resharpening (Sollberger 1971). This specimen is $8 \mathrm{~mm}$ thick and $25 \mathrm{~mm}$ in maximum width and has transverse snap fractures on both ends, possibly representing postdepositional breaks. The material is dark red and white striped Alibates agate.

\section{BIFACIAL GOUGES}

Two specimens are bifacial gouges that are most accurately described as bifacial Clear Fork tools (Turner and Hester 1985:205-208). They are chisellike planing tools that have a steep working edge (bit) angle. They are triangular or trapezoidal in outline and have relatively straight, bifacially worked lateral edges. The longitudinal cross section is generally planoconvex, and the transverse cross section is biconvex, but the dorsal surface tends to be morestrongly convex than the ventral surface in transverse section. Bifacial gouges are usually made of relatively hard, coarse-grained materials such as Potter chert or quartzites. They are generally assumed to have been hafted (Howard 1975:51-53). Measurements of the gouges are presented in Table 5 .

Specimen 1 from 41 GR590 is trapezoidal in outline. The bit is strongly concave and heavily wom to the extent that the working edge is slightly undercut. The dorsal and ventral ridges are slightly 


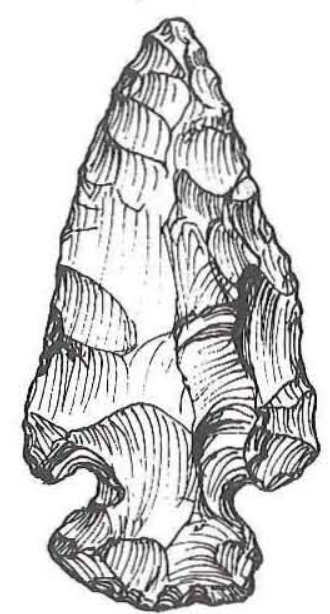

a

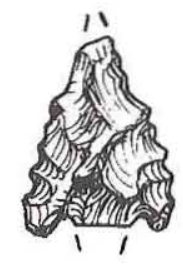

e

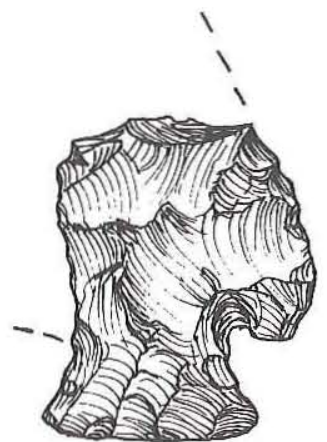

b

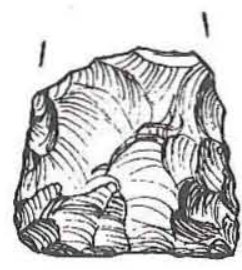

1

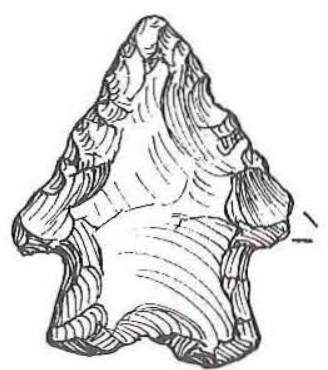

C
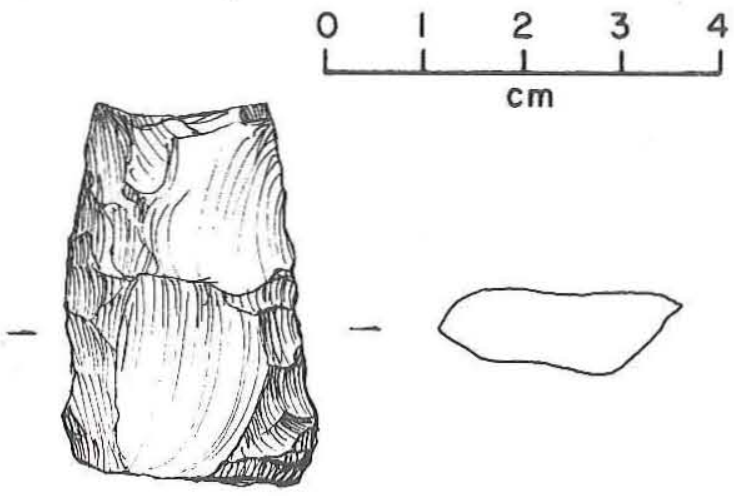

g
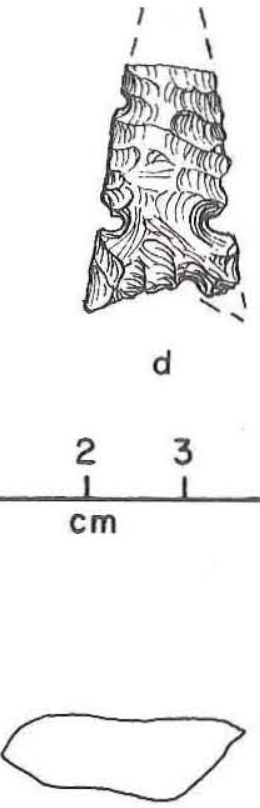
Figure 7. Bifacial tools. (a) Marcos dart point, 41GR583; (b) Marcos dart point, 41GR600; (c) untyped dart point, 41GR585;
(d) Washita arrow point, 41GR602; (e) untyped arrow point, 41GR585; (f) arrow point preform, 41GR585; (g) beveled knife fragment, 41GR585.

rounded, most likely as a result of hafting. The material is a fine- to medium-grained quartzite that retains no cortex and is banded gray and brown with some red splotches. It is very similar in grain size and texture to Potter chert and is probably a local material; it appears to have been heat treated.

Specimen 2 (Fig. 8a) from 41GR595 is triangular in outline, and its slightly convex bit exhibits extensive use-wear. The dorsal face retains ca. $20 \%$ cortex, and slight rounding of the high points on the dorsal ridge may have resulted from hafting. The material is Potter chert that appears to have been heat treated.

\section{Unifacial Tools}

\section{UNIFACIAL GOUGES}

Unifacial gouges are chisel-like planing tools that are similar in form, and presumably function, to bifacial gouges. They may vary in outline but are usually triangular or rectangular, and they always have a steep working edge (bit) angle. The bit edges also may vary, being straight, concave, or convex; they sometimes have extensive use-wear, and the working edge may even undercut the bit angle. Bits also may exhibit relatively little use-wear since the tools were apparently resharpened on a regular basis. The lateral edges are generally straight and unifacially worked into the proper shape. They frequently have extensive use-wear, some of which may be attributed to hafting (Howard 1975:51-53). The ventral face is usually a smooth, relatively flat or slightly curved ventral flake surface and quite frequently has a bulb of percussion at the butt. The dorsal face commonly has some cortex remaining or is entirely covered with cortex except for the unifacial flaking along the lateral and bit edges.

Ten unifacial gouges were collected (see Table 5 for measurements). Six (Specimens 1-6) are 


\begin{tabular}{|c|c|c|c|c|c|}
\hline \multicolumn{6}{|c|}{ METRIC DATA FOR GOUGES* } \\
\hline Type & Site & Thickness & Maximum Length & Maximum Width & $\begin{array}{l}\text { Approximate } \\
\text { Bit Angle } \\
\end{array}$ \\
\hline Bifacial & & & & & \\
\hline $\begin{array}{l}\text { Specimen } 1 \\
\text { Specimen } 2\end{array}$ & $\begin{array}{l}\text { 41GR590 } \\
\text { 41GR595 }\end{array}$ & $\begin{array}{l}22 \\
22\end{array}$ & $\begin{array}{l}71 \\
82\end{array}$ & $\begin{array}{l}47 \\
50\end{array}$ & $\begin{array}{l}65-75^{\circ} \\
55-65^{\circ}\end{array}$ \\
\hline Triangular Unifacial & & & & & \\
\hline Specimen 1 & $41 \mathrm{GR} 573$ & 18 & 65 & 53 & $60-80^{\circ}$ \\
\hline Specimen 2 & 41GR573 & 22 & 61 & 43 & $85-90^{\circ}$ \\
\hline Specimen 3 & 41GR580 & 22 & 64 & 40 & $\mathrm{x}$ \\
\hline Specimen 4 & 41GR584 & 19 & 79 & 42 & $\mathrm{x}$ \\
\hline Specimen 5 & 41GR590 & 23 & 67 & 49 & $65-80^{\circ}$ \\
\hline Specimen 6 & 41GR603 & 23 & 62 & 48 & $70-90^{\circ}$ \\
\hline Rectangular Unifacial & & & & & \\
\hline $\begin{array}{l}\text { Specimen } 7 \\
\text { Specimen } 8\end{array}$ & $\begin{array}{l}\text { 41GR591 } \\
\text { IF } 8\end{array}$ & $\begin{array}{r}24 \\
9\end{array}$ & $\begin{array}{l}67 \\
64\end{array}$ & $\begin{array}{l}47 \\
31\end{array}$ & $\begin{array}{l}75-85^{\circ} \\
75-90^{\circ}\end{array}$ \\
\hline Irregular Unifacial & & & & & \\
\hline Specimen 9 & 41 GR595 & 25 & $58^{*}$ & 50 & $70-80^{\circ}$ \\
\hline Specimen 10 & 41GR599 & 20 & 50 & 41 & $75-85^{\circ}$ \\
\hline
\end{tabular}

triangular in outline. These tools are commonly called Clear Fork gouges or unifaces (Turner and Hester 1985:205-208) and are considered to be temporally and functionally related to the Clear Fork bifacial gouges. Two specimens (Specimens 7 and 8) are rectangular in outline, while two others (Specimens 9 and 10) are irregular in outline and do not fit into either the triangular or rectangular categories.

Triangular Specimen 1 (Fig. 8b) from 41GR573 is of black, coarse-grained Ogallala quartzite and appears to have been made on a primary flake. The ventral face is smooth except for the bulb of percussion near the rounded butt. Extensive wear on the butt and lower portion of both lateral edges probably represents haft-wear. The dorsal face is a smooth stream-rolled cortex except for unifacial trimming of the straight lateral and bit edges.

Specimen 2, also from 41GR573 and triangular, is of Potter chert. There is ca. $30 \%$ cortex remnant on the dorsal face, and the ventral face is a smooth, slightly curved flake scar. The bit edge is straight and has minimal use-wear, but a convex bump in the center of the bit exhibits more-pronounced use-wear. One lateral edge is straight, while the other is convex, giving the gouge an asymmetrical appearance. Both lateral edges and the rounded butt are also worn, possibly as a result of hafting.

Specimen 3 is a triangular gouge of Potter chert from 41GR580. It has ca. $20 \%$ dorsal cortex and a smooth, slightly curved ventral surface. It appears that the proximal end of the flake (i.e., the platform) forms the distal end of the tool. The butt is well rounded, and the lateral edges are straight; they all exhibit use-wear. Most of the bit is broken, and only a small remnant exhibits use-wear.

Triangular Specimen 4 from 41GR584 is of Potter chert (possibly heat treated). It has ca. $80 \%$ dorsal cortex and appears to have been made from a 

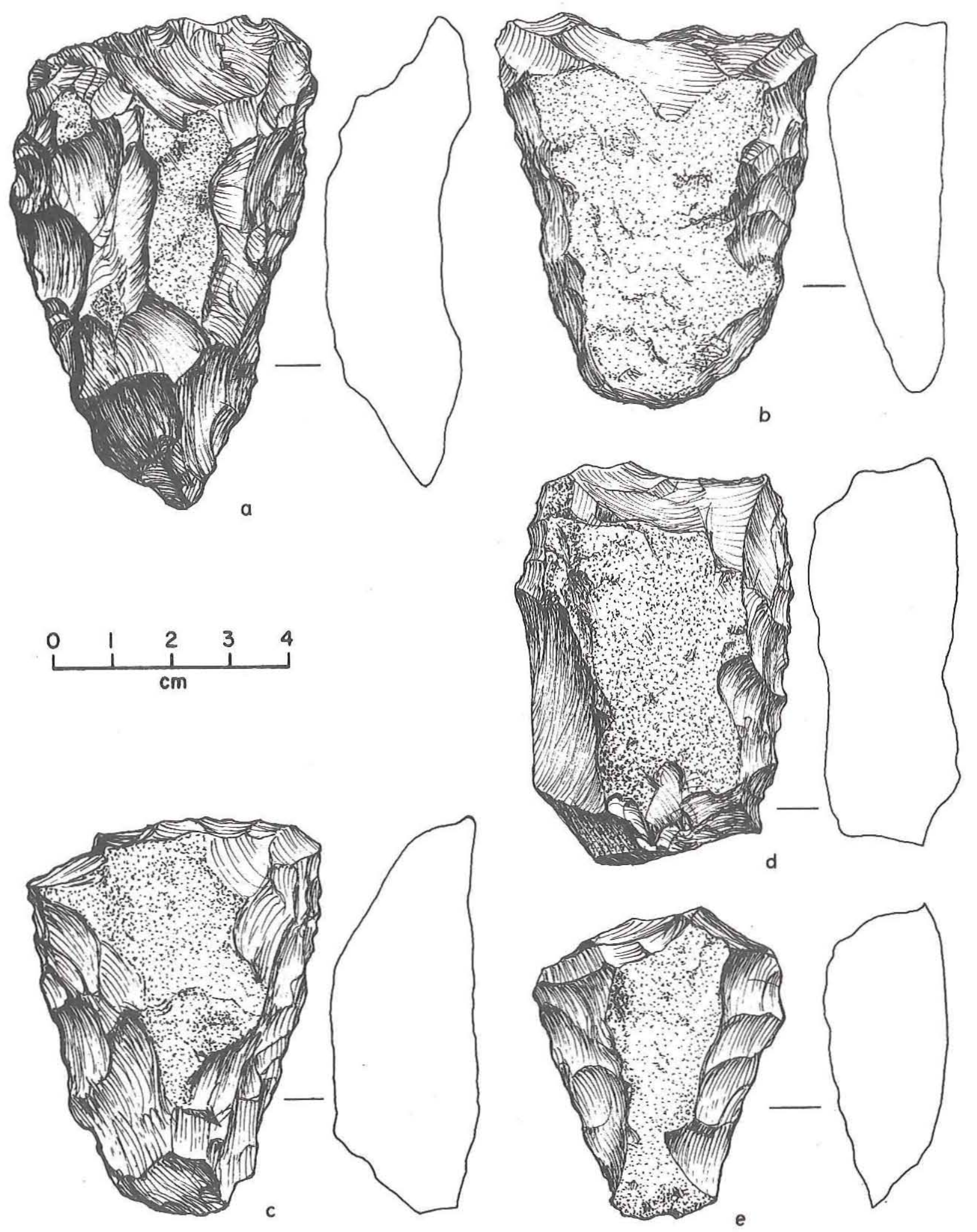

Figure 8. Gouges. (a) Bifacial gouge, 41GR595; (b) unifacial triangular gouge, 41GR573; (c) unifacial triangular gouge, 41GR590; (d) unifacial rectangular gouge, 41GR591; (e) unifacial irregular gouge, 41GR599. 
primary flake, but the ventral face has no flake features. One lateral edge is straight, while the other is convex, imparting an asymmetrical appearance. Both lateral edges, the butt, and the dorsal ridge exhibit use-wear suggesting hafting. The bit is broken; moderate use-wear is visible on the one small remaining corner.

Specimen 5 (Fig. 8c) is a triangular gouge of Potter chert from 41GR590. Cortex covers ca. 40\% of the dorsal face, but it is similar in color and only subtly different in texture (i.e., smoothness) from the flake scars. The butt appears to be the flake platform, and the ventral surface has a bulb of percussion but is otherwise flat. The lateral edges are straight, and the bit is straight except for a concavity on one corner. Minimal use-wear is evident on all edges. Slight rounding along the dorsal ridge suggests hafting.

Specimen 6 is also triangular, of Potter chert, and is from 41GR603. The material is relatively fine grained and appears to have been heat treated. There is a small remnant of cortex on the dorsal face, and the ventral face is flat with no obvious flake features. The butt is rounded, while the bit is relatively straight with only a slight concavity. The tool appears asymmetrical because one lateral edge is convex with a low edge angle (ca. $45^{\circ}$ ) and has no unifacial edge modification, while the other lateral edge is straight, very steep $\left(60-75^{\circ}\right)$, and has extensive unifacial reworking. All edges of the tool exhibit heavy usewear or rounding. The lack of any pronounced rounding along the dorsal ridge suggests that this specimen was not hafted or perhaps was hafted only temporarily. If it was never hafted, it may have been a multifunctional gouge/scraper tool. Alternatively, it may have been a hafted gouge that was subsequently reused as a scraping tool.

Specimen 7 (Fig. 8d), a rectangular gouge of Potter chert (possibly heat treated), is from 41GR591. Its dorsal surface retains ca. $70 \%$ cortex, and it may have been made on a primary flake. The ventral face has a slight transverse concave curvature and is smooth except for minor pitting due to impurities in the stone. A slight bulge near the butt may be a remnant of the percussion bulb. This gouge is uniformly thick; a portion of the butt and one lateral edge are battered and step fractured, probably a result of shaping during manufacture. The other lateral edge and the slightly concave bit are unifacially worked and exhibit use-wear. There is no evidence to suggest that this specimen was ever hafted.
Specimen 8 is a rectangular, or slightly trapezoidal (it tapers toward the butt), gouge made from a pebble of fine-grained grayish brown quartzite of local origin. It was collected as Isolated Find 8. The ventral surface is entirely stream-rolled cortex. The butt is rounded, and both lateral edges are straight; one is cortex (i.e., the angular edge of the pebble), and the other is unifacially worked. Extensive use-wear on the butt and slight rounding of the lower portion of the lateral edges and the dorsal ridge suggest hafting. The bit is slightly concave and is extensively worn, undercutting the bit angle in the center of the concavity.

Specimen 9 is an irregular distal fragment of fine-grained quartzite from 41GR595. The material is greenish brown with black splotches and is most likely of local origin. A small cortex remnant is present on the dorsal face, while the ventral face is smooth and slightly curved. The proximal half of the tool is missing, but the lateral edges are sinuously irregular, one being generally convex while the other is concave. The bit is generally straight with slight concavities. All edges exhibit use- and/or haft-wear, and there is slight rounding on the dorsal ridge crest. The complete form of the gouge was probably subrectangular.

Specimen 10 (Fig. 8e) is a sinuous, teardropshaped gouge of Potter chert from 41GR599. The dorsal face retains ca. $40 \%$ cortex along the ridge crest, while the ventral face has no flake features but has a pronounced convex longitudinal curvature. Both lateral edges are unifacially worked and exhibit slight use- or haft-wear. Rounding on the high points of the cortex ridge also suggests hafting. The bit is strongly convex and is very steep, undercutting the bit angle in places. Only moderate use-wear is evident along the bit.

\section{MISCELLANEOUS SCRAPERS}

Three specimens are classified as miscellaneous scrapers. Specimen 1 from 41 GR573 is unifacial. It is $59 \mathrm{~mm}$ long, $29 \mathrm{~mm}$ wide, and $18 \mathrm{~mm}$ thick. It is roughly ovate in outline with both ends pointed and a projecting tip along one lateral edge. All edges exhibit extensive unifacial flaking, step fracturing, use-wear, and steep working edge angles (ca. 65$85^{\circ}$ ). The projecting lateral tip appears to be a graver and has a possible burinlike flake removal on the dorsal side. The material is white chert with clusters of red speckles and may be of nonlocal origin. 
Specimen 2 is unifacial, of Potter chert, and from 41GR578. It is roughly rectangular in outline with parallel straight lateral edges, one convex end, and one concave end. The specimen is $80 \mathrm{~mm}$ long, $42 \mathrm{~mm}$ wide, and $19 \mathrm{~mm}$ thick. The ventral surface is irregular and exhibits no flake features. The dorsal face retains ca. $20 \%$ cortex along the concave end. Three edges (the convex and concave ends and one lateral edge) are unifacially worked and exhibit slight use-wear. The edge angles vary from ca. $35^{\circ}$ to $60^{\circ}$.

Specimen 3 is a unifacial scraper of Potter chert (possibly heat treated) from 41GR580. It is roughly rectangular with three straight edges and one short pointed end. The specimen is $59 \mathrm{~mm}$ in length, $46 \mathrm{~mm}$ in width, and $26 \mathrm{~mm}$ in thickness. The ventral face is flat with a percussion bulb remnant at the pointed end. The dorsal face has ca. $40 \%$ cortex that extends down to form the straight short edge. The two lateral edges and the pointed end are all unifacially worked. The latter has only moderate use-wear, while the lateral edges exhibit heavy step fracturing and use-wear that undercuts the edge angle in places. The edge angles vary from $65^{\circ}$ to $85^{\circ}$.

\section{Other Artifacts}

Four other collected artifacts do not fall into the bifacial or unifacial tool categories. These include a cobble tool, a hammerstone, a core, and an unmodi- fied flake. The latter two were collected from shovel tests.

Specimen 1 is a cobble tool from 41GR585. It is a large $(106 \times 75 \times 53 \mathrm{~mm})$ rectangular stream nodule of very high quality, dark grayish brown Central Texas chert. One end is bifacially flaked and battered, and a few flakes have been removed from one side. The opposite end and one lateral edge also are extensively battered, and it appears to have been used as a chopper.

Specimen 2 is a hammerstone of dark red Ogallala quartzite that was collected from a small over-hang shelter as Isolated Find 1. It is an ovalshaped stream nodule that is pointed on one end. It measures $111 \mathrm{~mm}$ in length, $55 \mathrm{~mm}$ in width, and $55 \mathrm{~mm}$ in thickness. The pointed end is slightly battered with a few small flakes removed.

Specimen 3 is an angular core of gray and white splotched chert from the shovel test at 41GR587. It is relatively small, $47 \times 31 \times 19 \mathrm{~mm}$, and appears to be exhausted. There are numerous flake scars and stepfractured edges; a small cortex remnant (ca. $5 \%$ of total area) is visible on one edge. The material is most likely a variety of Cretaceous chert, probably of local origin.

Specimen 4 is an unmodified tertiary flake from Shovel Test 1 at 41GR597. The material is an unidentified, high-quality, translucent brown chert. The flake is $15 \mathrm{~mm}$ in maximum dimension. 


\section{GEOARCHEOLOGICAL INVESTIGATIONS}

by C. Britt Bousman

\section{GEOARCHEOLOGY}

Previous geological investigations at Justiceburg Reservoir have shown the advantages of conducting geological investigations along with archeological fieldwork (Blum 1989; Abbott 1990). Not only does geological analysis provide information about the chronological development of landscapes and past environments but geoarcheological investigations also provide a much more accurate view of the context of archeological remains. In the Justiceburg Reservoir area, three major depositional environments occur, and these may be composed of a number of minor depositional environments. The three major depositional environments are the alluvial floodplains, alluvial/colluvial fans at the base of steep valley walls, and upland eolian sand sheets. The alluvial floodplains along the Double Mountain Fork of the Brazos River, Grape Creek, and other smaller tributaries are composed of a number of minor depositional environments that include point bars, natural levees, overbank floodplain deposits, and eolian dunes associated with sandy channel deposits. The nature of the floodplain depositional environments changes within Justiceburg Reservoir due to a floodplain constriction by canyons, and the specific differences are well described by Blum (1989) and Abbott (1990). Erosive environments are especially common along the steep valley and side canyon walls. This erosion often feeds sediments to small to mediumsized individual or coalescing alluvial/colluvial fans at the bottoms of the canyon walls. The distal ends of these fan deposits interfinger with floodplain alluvial deposits. In the uplands, eolian sand sheet deposits were recognized, but other depositional and erosive environments occur as well. These include small deflationary playas and associated eolian deposits, and small ephemeral channels and associated pond deposits. Thus, the Justiceburg Reservoir area in general and the wildlife mitigation area specifically have a number of depositional environments that can preserve archeological materials in good context, as well as erosional environments that can destroy in situ archeological occurrences. The geological work undertaken in this project was an attempt to better understand and document the geological contexts of the archeological occurrences.

\section{METHODS}

In the laboratory before commencement of the fieldwork, aerial photographs and topographic maps were inspected in order to identify promising areas for geological investigations in the project area. Relatively deep alluvial deposits were identified in the canyon, and a small vegetation anomaly was identified in the uplands. This vegetation anomaly extended transverse and across a small first-order upland drainage and appeared to be a sand dune that may have dammed the drainage channel.

Three days were spent in the field. The first half-day was used to gain familiarity with the project area and the geomorphic circumstances likely to be encountered. The remaining time was spent investigating the sediments at specific sites and specific localities identified during the archeological survey or in the laboratory as potentially useful in providing an understanding of the geomorphology of the project area. 
Fourteen backhoe trenches were dug and exposed sediments described (Profiles 2-12 and 14-16). Three additional geological exposures were documented. These include an eroding profile from a prehistoric site (41GR600), an alluvial cutbank in the bottom of the main canyon (Profile 13), and a profile in a roadcut (Profile 1). Profile 13 is the only profile described in an alluvial setting; the remainder are in the uplands.

The procedure for documenting the sediment characteristics uses the zone concept. A zone represents a homogeneous and contiguous sediment in terms of color, texture, structure, or other soil and/or sedimentary characteristics. A zone may represent a pedogenic horizon, a sedimentary layer, or a manmade or disturbed sediment. Colors were estimated with Munsell Soil Color Charts. Sediment textures were estimated by feel in the field according to the guidelines in Soil Survey Staff (1975:471). Soil structure was assessed by the definitions discussed by Soil Survey Staff (1975:474-476), and the general types are massive (no structure), blocky, prismatic/ columnar, platy, and granular/crumb. Other characteristics include mottles; calcium carbonate $\left(\mathrm{CaCO}^{3}\right)$ and manganese concretions, films, filaments or skins; pebbles and cobbles; artifacts; insect and rodent burrows; and surface characteristics. The lower boundaries of a zone also can be helpful in deciphering the processes responsible for the accumulation and alteration of sediments, and among other characteristics, boundaries can be very abrupt, abrupt, clear, gradual, and diffuse (Soil Survey Staff 1975: 462-463). Based on the nature of all these observations, zones can be assigned a soil horizon designation according to the guidelines discussed in Soil Survey Staff (1975:459-462) and upgraded in Bettis (1984:57-59) and Birkeland (1984:4-12, 353-361). Detailed profile descriptions are presented in the Appendix to this report.

\section{RESULTS}

\section{Surface Soills}

The surface soil types in the wildlife mitigation area can be lumped into three groups useful for assessing the potential contexts of archeological sites: paleustolls, inceptisols, and rough broken land (Richardson et al. 1975:78). Paleustolls are ancient mollisols with well-developed soil horizons (Soil Survey Staff 1975; Birkeland 1984:38-59). These are found in most of the higher elevations and flatter landscapes in the uplands. Inceptisols are weakly developed soils (Soil Survey Staff 1975; Birkeland 1984:38-59), and they reflect a relatively shorter duration of pedogenic development than the paleustolls, which suggests the sediment may not have been in place for a long period of time. Inceptisols in the wildlife mitigation area occur in three settings. The first is on a few elevated upland areas that may have undergone recent or quasicontinuous erosion or deposition. The second is along the upland margin at the canyon rim, but topographically below the paleustolls. These areas are geologically more active. The last geomorphic setting for inceptisols is a small section of alluvial sediments in the lower portion of the canyon. Each setting probably reflects a relatively young age of the sediments. Rough broken land does not have enough soil development for classification, except for small, unmappable areas of inceptisols, entisols, or aridisols (Richardson et al. 1975:2728 ). Rough broken land occurs in the actively eroding landscapes along the valley walls and bottoms of the larger canyon. Depositional environments in this soil type include alluvial/colluvial fans and limited alluvial deposits; however, erosive environments dominate this soil type.

Three small circular patches mapped as Randall clay soil, a vertisol, are immediately to the west of the wildlife mitigation area, and these mark small deflationary basins with seasonal playas. One of these playas is bisected by the new access road; it is little disturbed on the south side and could contain a significant sedimentary and paleoenvironmental record for the region. The other two were not inspected in the field, but analysis of stereoscopic aerial photographs indicates that these two are playas and one has an associated well-developed dune on its northwest side mapped as a Miles fine sandy loam soil. In the Southern Plains, dunes associated with playas are often rich sources of proxy paleoenvironmental data (Wendorf and Hester 1975).

\section{Upland Sand Sheet and Gravel Deposits}

In general, most upland sediment profiles in the wildlife mitigation area, i.e., all but 41GR600, are capped by a brown to reddish yellow to yellowish brown sand to silt loam that varies in thickness from 3 to $190 \mathrm{~cm}$. This is the blanketing sand sheet deposit that is mainly the result of eolian deposition. Previous investigations on the south side of the river 
had dated humates from soils in the sand sheet, and the associated radiocarbon ages were 4730 and 2770 years B.P. (Blum 1989:101; Abbott 1990:53); however, no radiocarbon dates are available from profiles on the north side of the river. Some of the profiles in the wildlife mitigation area were disturbed by root plowing, and this has destroyed soil horizons in all affected profiles and archeological context at sites. The soils do not appear to be as well developed or as clayey on the north side of the reservoir as compared to the south side (Blum 1989:99; Abbott 1990:51-53). This could be due to a number of factors, including sediment supply and age of the sediments. No wind direction information is available for the immediate vicinity of Justiceburg Reservoir, but wind information for Lubbock demonstrates that in the spring, summer, and fall, winds most often blow from the south (Bomar 1983:178-179). If these wind patterns apply for the Justiceburg region, then they suggest that the eroding escarpments, floodplain, and riverbed in the reservoir area may have served as a significant source of sediments for the sand sheet on the north side in the wildlife mitigation area but not for the south side. The uplands on the south side would not have been as close to a primary sediment source for eolian deposition. Thus, the southern upland would be less likely to contain coarser sediments simply because of its greater distance to a sandy sediment source.

Six profiles, i.e., Profiles 7, 8, 9, 10, 12, and 14, have calcium carbonate $\left(\mathrm{CaCO}^{3}\right)$-cemented gravel deposits at their bases, while others, i.e., Profiles 1 , $2,3,5,6,11$, and 15 , have no gravel layers at their base and the upper sand sheet sediments rest directly on sandstone bedrock. No simple or clear spatial pattern was discerned in the distribution of the basal $\mathrm{CaCO}^{3}$-cemented gravel layers. These $\mathrm{CaCO}^{3}$ cemented gravels are probably truncated Pleistocene alluvial/colluvial fan deposits associated with the erosion of the Caprock and may be the local expression of the basal unit of the informally defined Lingos formation (Caran and Baumgardner 1988). The nearest known occurrence of the Lingos formation is mapped approximately $16 \mathrm{~km}$ (10 miles) north of the present project area immediately beyond the North Fork of the Double Mountain Fork of the Brazos River Valley (Caran and Baumgardner 1988:287). Using estimates of Caprock Escarpment retreat rates of $60 \mathrm{~m} / 1,000 \mathrm{yr}$ to $180 \mathrm{~m} / 1,000 \mathrm{yr}$ (Gustavson and Simpkins 1989:42) and measurements of distance from the project area to the modern Caprock, ca.
$40.6-44.1 \mathrm{~km}$, the rough age for a possible beginning for the colluvial deposition that resulted in the accumulation of the gravels can be estimated as occurring between $226,000-735,000$ years ago, i.e., the middle Pleistocene. The documented gravels need not be of that age and could be younger redeposited sediments, but it is unlikely that the gravels could predate the middle Pleistocene.

The same rates of retreat can be used to estimate the approximate position of the Caprock at various times that are more relevant to understanding Southern Plains archeology. For example, at ca. 12,000 years ago during Clovis occupation of the Southern Plains, the eastern boundary of the Caprock may have extended 720-2,160 $\mathrm{m}$ beyond its present location into the Rolling Plains. If the Caprock was used as a bluff for bison drives by Clovis or more-recent hunters, then the rates of Caprock Escarpment retreat have important implications for kill site locations and site preservation. Clearly, erosion is related to many factors, including climate and vegetation, and changes in these parameters might alter the estimated erosion rates. Additional refinement of retreat rates might be gained by dating buried soils on colluvial fans formed below the modern Caprock Escarpment such as present in the roadcut on U.S. Highway 84 northwest of Post. It is less clear how these escarpment retreat rates apply to canyon formation in the Justiceburg Reservoir area. Sandstone bedrock in the reservoir area appears to be more resistant to erosion, but the oldest alluvial valley deposits in Justiceburg Reservoir date to the terminal Pleistocene (Blum 1989:94; Abbott 1990:48-49), and these could represent the first set of deposits laid down in the present valley floors. This issue is complex, and little data have been recovered that could be used to address the question with certainty.

\section{Colluvial Slope Deposits}

Besides the sand sheet deposits, three other depositional contexts require discussion; these are upland pond deposits, alluvial valley fills, and colluvial slopes. The latter two contain archeological materials. At 41GR600, abundant artifacts were observed eroding from a low scarp on a sloping cutbank above a small tributary stream. Approximately $30 \mathrm{~cm}$ of fine colluvial sediments were stratified over gently sloping calcareous mudstone bedrock. A dark grayish brown friable loam with weak coarse subangular blocky structure was 
documented between $0.5-15 \mathrm{~cm}$ below the surface. Within this zone were abundant lithic artifacts, firecracked rocks, charcoal, bones, and freshwater mussel shells. This represents an Ab horizon that in part is the result of the human occupation. Below the $A b$ horizon is a brown friable silt loam with weak coarse subangular blocky structure, and this represents a Bkb horizon. In sections of the small eroded escarpment away from the archeological site, the expression of the $\mathrm{Ab}$ horizon is much weaker with less organic staining. This difference provides a clear indication of the amount of organic material that was introduced into the sediments by the human occupants. It is possible that the preservation of vertebrate and invertebrate faunal remains is in part due to this introduction of organic materials which altered the soil chemistry (probably the $\mathrm{pH}$ ) enough to favor faunal preservation. The sediments at 41 GR600 are fine enough to suggest that the archeological materials probably are preserved with little spatial disruption or relocation. The fine-grained textures also hint at the possibility that some of this sediment was deposited directly on the site by eolian processes or redeposited by slopewash.

\section{Alluvial Valley Fills}

Profile 13 consists of $240+\mathrm{cm}$ of alluvial sediments. The profile is in the main canyon bottom, and the alluvial sediments interfinger with colluvial sediments with gravel stringers a few meters east toward the valley wall. Three stratigraphic units were documented. The upper two sedimentary units are a total of $50 \mathrm{~cm}$ thick and consist of yellowish red sandy loams with an unconformity and gravel lens separating the two units. The lower alluvial unit is capped by a truncated soil with a $3 \mathrm{~B}$ tkb horizon. In this soil are thin wavy discontinuous ash lenses at about $115 \mathrm{~cm}$ below the surface. The 3Btkb horizon grades down into a $3 \mathrm{Ckb}$ horizon at $160 \mathrm{~cm}$ below the surface. Even though this is a fairly deep profile, it may not represent much time as previous research at Justiceburg Reservoir (Blum 1989; Abbott 1990) and in other areas of the region (Gustavson 1986) has demonstrated the rapidity of sediment accumulation in alluvial contexts.

\section{Upland Pond and Channel Deposits}

Two fluvial deposits were documented in the uplands, and each is capped by sand sheet sediments.
Immediately west of the wildlife mitigation area and exposed in a roadcut is Profile 1. It consists of a 35-cm-thick cap of brown sand over a light brownish gray to gray clay loam with strong medium angular blocky structure in a depression cut into the sandstone bedrock. The brown sand is upland sand sheet deposit. The blocky gray clay loam could be a small infilled arroyo channel, but more probably it represents a pond deposit. This site was completely invisible on aerial photographs. It is probably early Holocene or older in age if previous radiocarbon ages on the upland sand sheet and late Pleistocene soil development can be used as rough gauges of age (Blum 1989:92-97, 101; Abbott 1990:51-53).

As discussed at the beginning of this chapter, a possible sand dune was identified on aerial photographs before fieldwork began. This feature extended transverse to and on both sides of a small upland first-order tributary well away from the canyon rim. As these types of features often have associated pond or channel deposits immediately upstream of the dune, and the dunes could have associated buried archeological remains, a plan was made to investigate the area with a series of backhoe trenches. After inspecting the feature, it was obvious that it was an unusual sandstone bedrock outcrop. Nevertheless, a trench (Profile 2) was dug into the crest of this rise, and interlocking sandstone slabs were encountered at $60 \mathrm{~cm}$ below the surface. No specific evidence was recognized as to why this bedrock feature would occur, but it could still function similar to a dune and allow the formation of pond or channel deposits to accrete upstream. Three additional trenches (Profiles 3,4 , and 16) were dug in positions expected to contain pond sediments, channel deposits, or possibly archeological materials.

Profile 3 was the first trench excavated, and it was placed immediately upstream of the bedrock bench in the modern stream channel. If no pond or channel deposits were encountered here, then it would be unlikely that the bedrock feature caused the accumulation of water and thus created a greater potential for the occurrence of prehistoric occupations. Three sedimentary units stratified directly above bedrock were documented. The middle unit clearly is a dark blocky clay channel deposit that interfingers with the overlying silt loam along the channel margin. The lower unit is also a clayey channel deposit that pinches out toward the channel wall against the sloping bedrock which forms the valley profile. The upper unit is the eolian cover sand deposit, and it 
becomes thicker toward the valley wall. No archeological remains were discovered, but this profile demonstrates the accretion of fluvial-deposited sediments that themselves imply a potential for prehistoric occupations along the margins of the channel. In addition, these deposits offer the possibility of providing proxy paleoenvironmental data such as phytoliths or pollen, and they can be dated easily by radiocarbon.

Two other trenches, Profile 4 and Profile 16, were excavated in areas expected to expose pond deposits. Profile 4 is on the north slope of the drainage and has $9 \mathrm{~cm}$ of strong brown loam over $65 \mathrm{~cm}$ of reddish brown to yellowish red moderate medium subangular blocky clay loam. This sits on a pink calcium carbonate with pebbles. Profile 16 is in the middle of the drainage but upstream of Profile 3. This profile has $50 \mathrm{~cm}$ of sandy loam and loam capping $105 \mathrm{~cm}$ of yellowish red to dark reddish brown clay loam. The lower $65 \mathrm{~cm}$ of the clay loam has a moderate fine subangular blocky structure. The clay loams in Profile 16 sit on a yellow calcium carbonate zone. The blocky clay loams appear to be truncated soils (Btkb horizons), and the overlying loams are believed to represent more-recent sand sheet deposition. The increased thickness of the overlying loam in Profile 16 is likely due to its topographic position which would favor increased slopewash from the uppermost portion of this small upland basin. Profile 4 is positioned farther up the side of the drainage, where it would receive much less sediment from slopewash or could even have undergone some erosion. The age of the clay loam soils is unknown, but archeological materials could be contained within them. It is possible that the middle channel deposit in Profile 3 is younger than the truncated clay loam soils in Profiles 4 and 16, but this cannot be verified with the present field data. These two profiles (Profiles 4 and 16) are similar in many respects to those described previously in uplands south of the river in low-lying situations, and it is possible that the soils in Profile 4 and Profile 16 are as old as those dated from the south side of the river. If archeological materials are present around the Profile 3 fluvial deposits, then it is most likely that artifacts would be contained in this buried soil flanking the channel margin.

\section{CONCLUSIONS}

The results of the geoarcheological investigations suggest that archeological materials may be contained in some upland sediments with well-preserved archeological contexts. This was especially true for 41GR600 where an archeological occupation on a gradual slope was covered by colluvial and possibly eolian deposits. On this site, the introduction of organic materials by the human occupants has apparently assisted in the preservation of faunal remains. However, a number of sites in the wildlife mitigation area at the canyon edge are disturbed by erosion, and many sites above the canyon rim are in areas that were root plowed during the last $20-30$ years. These processes detrimentally affect the context of archeological remains at some sites.

Additionally, a number of depositional environments have been identified. Previous geoarcheological investigations had identified the eolian deposition of sediments in the upland sand sheet and suggested that some of the soils in sand sheet sediments have been in place for up to $4,000-5,000$ years. Additional depositional environments were identified during the present project; these include playas with associated dunes, possible Pleistocene pond deposits, and upland channel deposits. Unfortunately, no archeological remains were found in association with these geological sites. Nevertheless, these new depositional environments could prove to be important sources of paleoenvironmental data such as pollen or phytoliths, which may be dated by radiocarbon assay. 


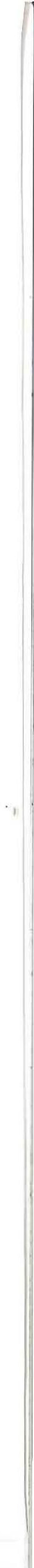




\section{SUMMARY AND CONCLUSIONS}

by Douglas K. Boyd

The archeological survey of the 2,240-acre wildlife mitigation area documented 1 historic and 32 prehistoric sites. The historic site, a turn-of-thecentury homestead, represents one of the more intact and discrete ranching complexes in the region. It contains remains of structures and features that were in continuous use for only a short period of time, ca. 1900-1915.

The 32 documented prehistoric sites is close to the predicted site density of 35 sites for the project area based on the results of the survey in the reservoir. The prehistoric resources include a single lithic scatter (41GR573), a faunal locality (41GR575), and six sites with evidence of lithic procurement only (41GR572, 41GR576, 41GR577, 41GR581, 41GR594, and 41GR595). The remaining 24 sites are prehistoric campsites, 12 of which also contain evidence of lithic procurement. The lithic scatter is, by definition, a relatively insignificant site. The faunal locality provided no definite evidence of cultural affiliation and most likely represents an isolated mature bison that died naturally and was subsequently buried in an alluvial terrace. The bulk of the prehistoric data, then, are derived from the open campsites and, to a lesser degree, from the lithic procurement areas.

Gravels of the Quaternary Lingos formation are abundant in the project area, as they are throughout the main reservoir area (Boyd et al. 1989:Figure 23). They occur as sporadic gravel outcrops which vary in the size, quantity, and quality of lithic materials, but collectively they provided a significant lithic source for the prehistoric inhabitants of the region and were intensively utilized. Eighteen sites in the wildlife mitigation area have evidence of lithic procurement activities. This density of lithic procurement areas, 18 sites in ca. 1,000 acres of canyonlands (excluding uplands), is comparable to that noted in the reservoir survey of 118 sites in ca. 8,600 acres (Boyd et al. 1989:107-110). These lithic procurement areas retain low research potentials because of the surficial nature of the gravel outcrops, their continuous use for thousands of years, and the inability to separate obviously mixed components.

Of the prehistoric campsites in the wildlife mitigation area, only five can be temporally defined; one is undefined Archaic (41GR599), two are late Archaic (41GR583 and 41GR600), and two are Late Prehistoric (41GR585 and 41GR602). The absence of early sites (i.e., Paleoindian and early and middle Archaic) was expected based on prior survey results in the adjacent reservoir area. This phenomenon appears to be widespread in the Lower Plains region (Boyd et al. 1989:197-198) and is attributed to three factors. First, there probably were few early sites to begin with. Second, extensive erosion in the canyonland valleys and along the upland margins has removed most of the late Pleistocene and early Holocene sediments hosting early sites. Finally, the rare preserved early sites retain low archeological visibility (e.g., sparse cultural materials with few diagnostic artifacts).

Collectively, the prehistoric campsites suggest intensive use of the canyonlands in the project area, particularly near the springs where water was probably available year round. The largest and most intensively occupied campsites are clustered near major springs, a fact that is hardly surprising in a region that averages only 19 inches of rainfall a year. 
In contrast, an ephemeral use of the uplands is suggested. The occurrence of several upland sites (41GR588, 41GR593, 41GR598, 41GR601, 41GR602, and 41GR603) with very similar characteristics is intriguing. All of these sites have sparse, surficial cultural materials that appear to represent ephemeral occupations. Only one of these sites (41GR602) produced a diagnostic artifact (a Washita arrow point which indicates a Late Prehistoric occupation). The upland setting of these sites on prominent rises with good views of the surrounding terrain in all directions is similar. It also appears that most of these locations (all except 41GR602) were selected because they contain isolated outcrops of sandstone bedrock. Such outcrops are rare in the uplands, and the next-closest sources for stones are along the upland margin/canyon rims. A possible selection factor is that all of these sites have thin soils devoid of large vegetation, i.e., the thin soils cannot support mesquite trees. Another similarity is that all are located quite some distance, over $0.5 \mathrm{~km}$ in all cases, from major drainages or springs.

A plausible theory explaining these sites is that they are all Late Prehistoric II, Protohistoric, or Historic Indian encampments. They appear to represent very short term occupations, perhaps by nomadic bison hunters who exploited upland rather than canyonland resources. Several circumstantial lines of evidence support this theory. The relatively great distance from water sources suggests that the site occupants had some form of water containers, perhaps ceramics and most certainly skin water bags, and some form of transportation such as horses or dogs. Although formal tools are rare at these sites, they include unifacial scrapers, large choppers, and quartzite manos, which can be associated with hide and bone working. There also appears to be a high percentage of nonlocal lithic materials, mostly Edwards chert, represented. The presence of sandstone outcrops at most of these sites also suggests a need for easily accessible rocks for various activities such as hearths or for weighting down temporary structures such as tipis.

It is to notable that, in spite of the intensive survey coverage of the bluffs in the wildlife mitigation area, no occupied rockshelters or rock art sites were found. A single isolated find, a battered quartzite cobble (Isolated Find 8), was found in a small bluff edge overhang, but no occupational debris was associated. The lack of occupied shelters and rock art is probably due in part to differences in the bedrock strata of the wildlife mitigation area as compared to the reservoir area. In the wildlife area, the Triassic sandstone layer forming the canyon rim is relatively thin, and there appears to be much less shelter development. Shelter formation there is probably very rapid. Overhanging ledges may have developed into small shelters which were temporarily occupied, but they probably eroded away within the span of a few hundred years or less so that there is very little potential for preservation of any significant rockshelter deposits. It also appears that the friable Permian sandstone layers, which are abundant throughout the wildlife mitigation area but not in the main reservoir, are perhaps too soft to have been suitable for rock art or its preservation for any significant length of time.

Features observed in the project area are similar to those noted during the survey of the reservoir area (Boyd et al. 1989:112-123). The most common feature type, small clusters $(<1 \mathrm{~m}$ in diameter) of sandstone slabs, is generally thought to represent cooking/heating hearths. Clusters of fire-cracked Potter chert fragments are the next most common feature type, and they have been variously interpreted as boiling stone dumps, remnants of roasting pits, or residue that was discarded during the process of heat treating other lithic materials. In addition to these, 26 bedrock mortars were documented at six sites (Table 6). All were found in open campsites along stream channels, and all are of the pointed-oval type illustrated in Boyd et al. (1989:Figures 21 and 22). Of those found at campsites that can be temporally defined, the largest number are at late Archaic sites, although the 15 mortars at 41 GR583 are also in close proximity to Late Prehistoric site 41GR585. The occurrence of bedrock mortars near both late Archaic and Late Prehistoric sites also was noted in the reservoir area (Boyd et al. 1989:Table 13). It is presumed that these features served in some capacity related to the processing of vegetal materials.

The artifacts observed in the wildlife mitigation area are also similar to those reported in the reservoir (Boyd et al. 1989:123-126, Appendix A). Temporally diagnostic specimens collected during the survey include four dart points, two arrow points, a probable arrow point preform, and a beveled knife fragment. Other collected artifacts include gouges, several of which are of the Clear Fork type, and a few miscellaneous tools.

The dart points include two Marcos and an untyped (reworked) stemmed point. These appear 


\begin{tabular}{|l|l|l|}
\hline \multicolumn{3}{|c|}{ TABLE 6 } \\
& & Number of \\
Sedrock \\
Site No. & Temporal Affiliation & Mortars* \\
\hline 41GR582 & Undefined Prehistoric & 2 \\
41GR583 & Late Archaic & 15 \\
41GR584 & Undefined Prehistoric & 4 \\
41GR592 & Undefined Prehistoric & 2 \\
41GR599 & Undefined Archaic & 1 \\
41GR600 & Late Archaic & 2 \\
\hline TOTAL: & & 26 \\
\hline *All are pointed-oval shape. & \\
\hline
\end{tabular}

consistent with a late Archaic tradition in the Lower Plains that is characterized by several varieties of stemmed corner-notched points. Ensor, Lange, Marshall, and possible Marcos points were recovered at the late Archaic Summers Complex type site, 34GR12, in Southwestern Oklahoma (Leonhardy 1966:20-23, Figure 7). It is thought to be related to the late Archaic bison hunters in the Lower Plains (Hughes 1977:122) where bison-kill sites have yielded similar artifacts. Similar points also have been recovered from the Twilla, Bell, Collier, Sitter, Finch, and Hoover sites (Hughes 1977:Figures 5, 6, 7, 13, and 20). These are all interpreted as late Archaic bison kills, and the various points are classed into three varieties that are similar to the following types: Variety 1 points are most similar to Marcos but also resemble the Ellis and possibly Castroville types; Variety 2 points are most similar to Ellis and possibly the Palmillas and Williams types; and Variety 3 points are most similar to Ensor but also resemble the Palmillas and Trinity types (Hughes 1977:36, 125-126).

This late Archaic bison-hunting tradition seems to be well represented in the Lower Plains region but also appears to be manifest in West Texas at Bonfire Shelter in Val Verde County, over $385 \mathrm{~km}$ (ca. 240 miles) south of Garza County. Late Archaic Bone Bed 3 contained Castroville-like and Montell points (Dibble and Lorrain 1968:Table 4, Figures 23 and 24). Of particular note is the slight fishtail stem on one Bonfire specimen (Dibble and Lorrain 1968: Figure 23-k) that is very similar to the slightly expanding stem and concave base of the reworked point (untyped) from 41GR585. These specimens appear to be vaguely similar to the Martindale type (Suhm and Jelks 1962:213, Plate 107).

Artifacts diagnostic of the Late Prehistoric period include the three arrow points (one is a preform) and the beveled knife fragment. Only one of the arrow points could be typed; the specimen recovered from 41GR602 is a Washita, which is one of the more ubiquitous point types found throughout the Southern Plains. Washita is not a particularly sensitive time marker since its manufacture and use may span a relatively long time. The beveled knife fragment from 41GR585 is a unique Late Prehistoric bison-butchering (i.e., cutting and skinning) tool that developed distinctive alternating bevels as a result of repeated resharpening (Sollberger 1971). It also has a very wide distribution, apparently having been used by many different cultural groups. It is interesting to note that all four of the Late Prehistoric artifacts appear to be made of exotic lithic materials. The Washita arrow point and the arrow point preform are of different varieties of Edwards chert, while the untyped arrow point and the beveled knife fragment are of Alibates agate. Two other beveled knife fragments also made of Alibates agate were recovered from the reservoir area (Boyd et al. 1989:319). An increased use of nonlocal lithic materials, particularly Alibates agate, in the Late Prehistoric period is a phenomenon noted at Justiceburg Reservoir and throughout the region (Boyd et al. 1989:130-131).

Gouges are one of the most distinctive and abundant artifacts observed in the Justiceburg Reservoir vicinity, and 13 specimens were collected from the wildlife mitigation survey area. As expected, the gouges are all made of coarse-grained materials, predominantly Potter chert but also quartzite. Included are both bifacial and unifacial specimens of the Clear Fork type, which are generally thought to be Paleoindian and early and middle Archaic woodworking tools (Turner and Hester 1985:205-208). While this interpretation may hold true, the temporal range and function of gouges, particularly the Clear Fork type, have not yet been demonstrated for the Lower Plains region, and a general observation suggests that gouges were still in use during the late Archaic period. Clear Fork gouges have been recovered in apparent association with late Archaic materials at 34GR12 in southwestern Oklahoma (Leonhardy 1966:30-32).

The geoarcheological study (see Chapter 4) failed to locate any buried archeological sites but did 
provide geomorphic insights essential to interpreting the archeology of the region. The interpretations are in overall agreement with those of the previous geomorphic studies at Justiceburg Reservoir (Blum 1989; Abbott 1990).

The valley fill in the wildlife mitigation area appears to be relatively recent with rapidly deposited sediments indicating a dynamic fluvial system. Although no absolute dates were obtained for these sediments, very similar depositional sequences are well documented for the Double Mountain Fork of the Brazos River and its tributaries in the reservoir area. Interpretations of the upland sediments, however, go beyond the earlier interpretations because the present study concentrated on upland settings. These investigations found previously unrecognized upland depositional environments. Specifically, upland stream channel and/or pond sediments were documented in the wildlife mitigation area. Similar settings are likely to exist in the reservoir area, but the previous geomorphic work was very limited in the upland settings. The organic-rich upland stream and pond sediments potentially may contain buried archeological deposits and retain even greater potential for yielding extremely important paleoenvironmental data. Further, several large playa depressions located near the wildlife mitigation area (one bisected by the new access road) have excellent potential for providing paleoenvironmental data that are critical for understanding the prehistoric past.

The geomorphic study of the wildlife mitigation lands also demonstrates the existence of in situ prehistoric cultural deposits in the upland margin setting along the canyon rim. At 41GR600, extensive cultural deposits in primary archeological and geological context are preserved in upland sediments. Although prehistoric sites are common around the upland margin, intact buried deposits are rarely observed because severe recent erosion usually has extensively altered and deflated the archeological sites, rendering them highly visible. At 41GR600, the cultural materials were deposited in place, buried rather rapidly, and remain essentially undisturbed. The smooth, gently sloping bedrock bench provides limited potential for high-energy erosion at this site. The homogeneous fine-grained sediments represent an intact pedon with an A horizon enriched by culturally introduced organic materials, including well-preserved bones and mussel shells.

Collectively, the archeological survey, the historic archival research, and the geomorphic study provide a substantial archeological data base which builds upon the previous Justiceburg Reservoir cultural resources investigations. One historic and 32 prehistoric archeological sites have been documented in the wildlife mitigation area. These resources reveal much about the prehistory and history of the project area, particularly from the late Archaic period to the present. In addition, several upland geomorphic localities have been identified that have the potential to provide extremely useful paleoenvironmental data. The final chapter evaluates the 33 archeological sites relative to the criteria of the National Register of Historic Places and makes recommendations for the appropriate treatment of the significant resources. 


\section{ASSESSMENTS AND RECOMMENDATIONS}

by Douglas K. Boyd and Martha Doty Freeman

This final chapter deals with two separate but related issues. The first is the evaluation of the significance of the archeological sites within the wildlife mitigation tract and assessments of site eligibity for listing on the National Register of Historic Places. The second issue is the potential site impacts which may occur as the wildlife mitigation plan is developed and the recommended actions which should be implemented in order to protect and preserve or otherwise minimize or mitigate the impacts to the significant cultural resources.

\section{NATIONAL REGISTER ASSESSMENTS}

Eligibility for listing a property on the National Register of Historic Places is determined by the concept of significance. Cultural resources are considered significant in American history, architecture, engineering, or culture if they:

possess integrity of location, design, setting, materials, workmanship, feeling, and association, and

A. that are associated with events that have made a significant contribution to the broad patterns of our history; or

B. that are associated with the lives of persons significant in our past; or

C. that embody the distinctive characteristics of a type, period, or method of construction, or that rep- resent the works of a master, or that possess high artistic values, or that represent a significant and distinguishable entity whose components may lack individual distinction; or

D. that have yielded or may be likely to yield information important in prehistory or history [U.S. Department of the Interior, National Park Service, National Register Division 1982:1].

Cultural resources that possess sufficient integrity and meet one or more of the four criteria are considered significant and thus eligible for listing on the National Register of Historic Places. Hence, a significant resource is worthy of avoidance, protection, or mitigation through data recovery.

The evaluation of National Register significance of an individual property must take two factors into consideration: its overall integrity and its associations (i.e., with events, persons, and other similar properties). All different types of cultural resources are evaluated within the general framework described above but must be considered under slightly different orientations that are appropriate to specific property types. For example, a historic architectural or archeological site may be evaluated under any of the four criteria and assessed relative to a regional historic context, which serves "to place historic properties within the context of the broad patterns of history that created them, and to place any one 
example within a larger group of similar properties" (Maryland Historical Trust 1987:1). In contrast, prehistoric resources are generally evaluated only under Criterion D, especially in regions where the prehistoric cultural sequence is poorly understood. Under these circumstances, a prehistoric resource that has demonstrated integrity derives its significance through the important information that it may be likely to yield. Important information must be identified relative to the current understanding of a region's prehistory and to regional research questions. Thus, prehistoric research designs are analogous to historic contexts but are, out of necessity, of a more theoretical nature. A research design serves to place a region's prehistoric cultural sequence in theoretical perspective, identify research problems (i.e., hypotheses), and propose a plan for solving those problems (Goodyear et al. 1978:161).

One historic and 32 prehistoric archeological sites were documented during the survey of the Justiceburg Reservoir wildlife mitigation lands. Each of these sites is evaluated for National Register eligibility relative to the appropriate context or research orientation (Table 7).

\section{Historic Site}

The single historic resource, site 41GR586, is evaluated relative to the historic context "Agriculture in Texas: Ranching on the Western Rolling Plains, 1877-1945" (Freeman 1990b), which was developed during the Phase II cultural resources investigations at Justiceburg Reservoir (see Chapter 2). The registration requirements for historic properties under this context and all four of the National Register criteria are considered in the evaluation of this site, following the format defined by Freeman (1990c).

Registration requirements pertaining to the historic ranching context are straightforward (Freeman 1990c:121-123). Cattle-ranching sites in the western Rolling Plains must date from 1877-1945. Where standing structures are present, they should be good examples of their architectural type and should not have been substantially modified in the last 50 years. On sites where there are no standing structures, archeological deposits should retain sufficient integrity to indicate the locations, sizes, configurations, orientations, and uses of the features; such features should reflect the full range of ranching-related activities. The material culture should be sufficiently intact to address questions relating to market sources, activities and lifeways of inhabitants, and period and duration of site occupation.

Site 41GR586, which includes the remains of a homestead dugout, frame house, stone well, outbuilding, two trash deposits, and a corral, retains a high degree of integrity. The site was established in 1900 by William G. Williams, an employee of the Lexington Ranch Company and of Clark, Connell and Scharbauer, and it dates to the pivotal period in West Texas when the agricultural economy was changing from open to closed range. The site was established in response to the Four-Section Act of 1895 and testifies to the impact that the Act made on land-use practices in West Texas during the period 1895-1910. Dugouts such as the one at 41GR586 not only provided shelter for cowboys but also provided their employers with a mechanism to retain control of large areas of previously open range (Criterion A).

Dugouts such as that at the Williams homestead site were among the most widespread, utilitarian, vernacular, frontier architectural types in the late nineteenth and early twentieth centuries. They represented a direct response to mandates created by changing laws and to special functional requirements created by climate and availability of building materials. The later frame house which stood on the site was a representative example of the types of "second-generation" residences constructed on the plains. They testified to the growing availability and variety of building materials, and also to societal changes in the region as single, often transient, cowboy employees of large cattle companies married, acquired land, and contributed to nascent rural communities (Criterion C).

Finally, site 41GR586 is the location of one of a number of late nineteenth- and early twentiethcentury dugouts that have been recorded on the western Rolling Plains. More importantly, it appears to be one of the few within the vicinity of the Double Mountain Fork that was used for a discrete period of time (1900-1903) and then abandoned when the Williams family constructed and occupied a new residence on the site. The fact that the two structures were occupied sequentially and that the years of use encompass both the prerailroad and postrailroad periods may make it possible to discern the impacts that the railroad had on regional material culture. The relative topographic locations of the two main residential site features is interesting as well, as is the spatial relationship of the site and its components with other similar homestead sites in the context area. 


\begin{tabular}{|c|c|c|c|}
\hline \multicolumn{4}{|c|}{ TABLE 7} \\
\hline \multicolumn{4}{|c|}{ SUMMARY OF SITES AND NATIONAL REGISTER ASSESSMENTS } \\
\hline Site Number & Classification & Temporal Affiliation & $\begin{array}{l}\text { National Register } \\
\text { Eligibility }\end{array}$ \\
\hline 41GR481 & Campsite & Undefined Prehistoric & Not Eligible \\
\hline 41GR572 & Lithic procurement area & Undefined Prehistoric & Not Eligible \\
\hline 41GR573 & Lithic scatter & Undefined Prehistoric & Not Eligible \\
\hline 41GR574 & Campsite & Undefined Prehistoric & Not Eligible \\
\hline 41GR575 & Faunal locality & Undefined Prehistoric & Not Eligible \\
\hline 41GR576 & Lithic procurement area & Undefined Prehistoric & Not Eligible \\
\hline 41GR577 & Lithic procurement area & Undefined Prehistoric & Not Eligible \\
\hline 41GR578 & Campsite/lithic procurement area & Undefined Prehistoric & Not Eligible \\
\hline 41GR579 & Campsite/lithic procurement area & Undefined Prehistoric & Not Eligible \\
\hline 41GR580 & Campsite/lithic procurement area & Undefined Prehistoric & Not Eligible \\
\hline 41GR581 & Lithic procurement area & Undefined Prehistoric & Not Eligible \\
\hline 41GR582 & Campsite/lithic procurement area & Undefined Prehistoric & Unknown \\
\hline 41GR583 & Campsite/lithic procurement area & Late Archaic & Unknown \\
\hline 41GR584 & Campsite/lithic procurement area & Undefined Prehistoric & Unknown \\
\hline 41GR585 & Campsite & Late Prehistoric II & Unknown \\
\hline 41GR586 & Homestead & Historic & Eligible \\
\hline 41GR587 & Campsite/lithic procurement area & Undefined Prehistoric & Unknown \\
\hline 41GR588 & Campsite & Undefined Prehistoric & Not Eligible \\
\hline 41GR589 & Campsite/lithic procurement area & Undefined Prehistoric & Unknown \\
\hline $41 \mathrm{GR} 590$ & Campsite & Undefined Prehistoric & Not Eligible \\
\hline $41 G R 591$ & Campsite/lithic procurement area & Undefined Prehistoric & Not Eligible \\
\hline 41GR592 & Campsite/lithic procurement area & Undefined Prehistoric & Not Eligible \\
\hline 41 GR593 & Campsite & Undefined Prehistoric & Not Eligible \\
\hline 41GR594 & Lithic procurement area & Undefined Prehistoric & Not Eligible \\
\hline 41GR595 & Lithic procurement area & Undefined Prehistoric & Not Eligible \\
\hline 41GR596 & Campsite/lithic procurement area & Undefined Prehistoric & Not Eligible \\
\hline 41GR597 & Campsite & Undefined Prehistoric & Not Eligible \\
\hline 41GR598 & Campsite & Undefined Prehistoric & Not Eligible \\
\hline 41GR599 & Campsite & Undefined Archaic & Unknown \\
\hline 41GR600 & Campsite/lithic procurement area & Late Archaic & Unknown \\
\hline 41GR601 & Campsite & Undefined Prehistoric & Not Eligible \\
\hline 41GR602 & Campsite & Late Prehistoric & Not Eligible \\
\hline 41GR603 & Campsite & Undefined Prehistoric & Not Eligible \\
\hline
\end{tabular}

Finally, it may be instructive to compare employeeassociated sites of nineteenth-century cattle companies at both the "hand" and the managerial levels (Criterion D).

Because it meets three of the four National Register criteria and retains a high degree of archeological integrity, site 41GR586 is assessed to be eligible for listing on the National Register of Historic Places.

\section{Prehistoric Sites}

The 32 prehistoric archeological sites are evalu- ated relative to the "Model of Late Holocene Human Adaptation" (Boyd, Abbott et al. 1990:261-273) developed during the Phase II cultural resources investigations (see Chapter 2) and to the comprehensive research design (Boyd, Tomka et al. 1990; see Chapter 2) developed to guide the Phase III data recovery at Justiceburg Reservoir. Only National Register Criterion D is considered for evaluating these sites, and the important information that sites might yield is assessed relative to the general hypotheses and specific research questions presented in Chapter 2. Unfortunately, more often than not, survey-level information on prehistoric sites is not 
adequate to assess National Register eligibility relative to the research design.

Twenty-four of the prehistoric sites lack basic integrity of cultural deposits and cannot be expected to contribute significant information. These include six lithic procurement areas (41GR572, 41GR576, 41GR577, 41GR581, 41GR594, and 41GR595) which can, by the nature of their cultural deposits, contribute little important information. As discussed in Chapter 5 and demonstrated in previous investigations (Boyd et al. 1990:282), the lack of distinguishable components or periods of use negates the research potential of these sites. Similarly, a single lithic scatter (41GR573) is also, by definition, an insignificant site, and a single faunal locality (41GR575) contained minimal deposits and provided no definite evidence of cultural affiliation. The remaining 16 sites (41GR481, 41GR574, 41GR578, 41GR579, 41GR580, 41GR588, 41GR590, 41GR591, 41GR592, 41GR593, 41GR596, 41GR597, 41GR598, 41GR601, 41GR602, and 41GR603) are campsites or combination lithic procurement/campsites that fail to meet the minimum integrity requirements for prehistoric campsites described below. All 24 of the sites mentioned above are considered to have low research potentials and are assessed as not eligible for listing on the National Register of Historic Places (see Table 7).

Eight prehistoric campsites or combination lithic procurement/campsites (41GR582, 41GR583, 41GR584, 41GR585, 41GR587, 41GR589, 41GR599, and 41GR600) are of unknown eligibility for listing on the National Register. A National Registereligible prehistoric campsite must have cultural materials that can be isolated into components or reasonably discrete periods of use and must exhibit little or no evidence of disturbance of those deposits. Even though the age of the cultural deposits at some of these sites is not well defined, all eight appear to be relatively late (i.e., late Holocene) and contain discrete, undisturbed buried cultural components. Beyond meeting the minimum integrity requirements, all eight of these prehistoric campsites can potentially yield important information relevant to understanding changing human subsistence strategies and their relationship to changes in resource structure and abundance. The model of late Holocene human adaptation (Boyd, Abbott et al. 1990:261-273) provides the theoretical framework for assessing site significance. Each of these sites contains cultural deposits that might contribute not only to the general theoretical model of late Holocene human adaptation but also to specific research problems defined for the region (see Chapter 2). The following discussion summarizes the eight unknown eligibility sites and describes their specific research potentials.

Four of the prehistoric sites (41GR582, 41GR584, 41GR587, and 41GR589) cannot be assigned to a discrete time period since no diagnostic artifacts were recovered. All are located in an upland margin and/or lower bedrock bench setting, and all have somewhat similar buried archeological deposits. Given that the topographic settings and cultural materials of these sites are similar to other sites of known age, it is probable that these are late Archaic or Late Prehistoric I occupations. Therefore, these four sites potentially can contribute information relevant to any of the four general hypotheses and to specific research questions $1,2,4$, and 5-22 (see Chapter 2).

Two of the prehistoric sites (41GR583 and 41GR600) have buried cultural components that are tentatively dated to the late Archaic period. A third site (41GR599) is undefined Archaic, but based on similarities in cultural materials and setting, it may also be late Archaic. Thus, these sites also potentially can contribute information relevant to general hypotheses 1a, 2a, 3a, and $4 \mathrm{a}$, and to specific research questions 1, 4, 5-8, and 10-21 (see Chapter 2).

The final prehistoric site (41GR585) is considered to be a Late Prehistoric II campsite that could be a manifestation of the Garza Complex. This site potentially can contribute information relevant to general hypotheses $1 b, 2 b, 3 b$, and $4 b$ and to specific research questions 3-17 and 19-21 (see Chapter 2).

Under the comprehensive research design for Justiceburg Reservoir, each of these sites is likely to have a high potential for yielding data relevant to addressing the general theoretical hypotheses and the specific regional research questions. The surveylevel data, however, cannot confirm the exact nature of the various components represented or confidently assess their temporal or cultural affiliations. It is premature to fit these sites into the hypotheses and specific questions proposed in the research design based on the limited evidence available. Therefore, these eight sites must be considered to be of unknown eligibility for listing on the National Register of Historic Places. 


\section{RECOMMENDATIONS}

If the proposed wildlife mitigation area is developed, it will be subject not only to impacts related to the construction and maintenance of wildlife habitat but also to a variety of other impacts from ancillary land usage. Although no detailed plan for the development of the wildlife mitigation area has been compiled, it has been determined that it will probably include the following kinds of activities and corresponding impacts. Possible options to alleviate or minimize impacts are also considered.

Some crops will probably be planted in selected areas to provide wildlife with additional food and habitat. Seeding activities likely will be confined to level areas in the uplands and possibly along upland margins but are not likely to occur in the canyonlands or valley bottoms. Planting of crops will entail considerable ground disturbance to various depths, depending on the nature of the crops, planting techniques, and other factors. Crop planting could severely impact any cultural resources in the immediate vicinity, but it is also likely that seeding areas can be selected so as to avoid any impacts to significant resources.

Fencing as a means of subdividing the wildlife mitigation area for management purposes is likely to be done and could be quite extensive. Fencing of specific areas will entail a certain degree of ground disturbance, but fences can be intentionally placed so that significant resources will not be impacted. In fact, it is expected that fencing can be used to maximize the protection and preservation potential of significant sites by minimizing impacts from other sources. If fence construction in the immediate vicinity of significant archeological sites is unavoidable, this activity should be monitored by an archeologist.

In order to provide on-site management of the wildlife mitigation area, it is likely that a caretaker's residence and associated facilities (e.g., storage buildings) will be built. Construction of such facilities could have severe impacts on cultural resources. Such impacts should be avoided if at all possible, and it is likely that these facilities can easily be located in nonsite areas.

Some form of public access to the wildlife mitigation area will be incorporated into the longterm management plan. Public access is likely to include temporary, seasonal access to specific areas during various hunting seasons. It may also include full-time, relatively unresticted public access to all or parts of the wildlife mitigation area, possibly in the form of nature trails, picnic areas, scenic areas, and the like. Any such public access, especially if unrestricted throughout the project area, is likely to create severe impacts to the significant cultural resources. The sites, both prehistoric and historic, which would be most susceptible to impacts from public access are those which are most visible. Such high-visibility sites unfortunately invite vandalism. Sometimes it is only in the form of artifact collecting by people who are not aware that they may be harming valuable resources. All too often, however, it is in the form of organized relic hunting by artifact dealers who are aware of, but disregard, cultural resources laws, or it is in the form of wanton destruction of property by vandals who have nothing at all to gain.

Over the years, various strategies have been employed to insure that cultural resources in public areas are treated properly. Many resources have been lost because of failed strategies, but a great deal has been learned in the process. Three options are generally considered to be the most realistic and cost-effective methods for long-term management of significant and highly sensitive cultural resources in public areas. The first option is to restrict the public's access to the sensitive sites or areas to avoid impacts altogether, thus preserving the resource. This option is often the most cost effective and is the preferred solution in many cases. Occasional site monitoring (i.e., visits to the site to insure that the site is not being vandalized) is usually needed, even if public access is restricted.

The second option is to allow unrestricted access but only in conjunction with site monitoring on a regular basis. In addition, there are sometimes measures which can be implemented to reduce a site's high visibility (i.e., to hide the site) or inform visitors of laws regarding cultural resources on public property. This option is most feasible in areas where management or caretaker personnel monitor all resources on a regular basis, such as in parks and recreation areas. Regular site monitoring is not cost effective in the long run, however, if it cannot be supported by appropriate finances and personnel.

The third option is to mitigate a site, i.e., conduct archeolgical data recovery, so that unrestricted access can be allowed without fear of future impacts. This option has a relatively high initial cost, but no expenses are incurred after the mitigation is completed. 
These three options are certainly not the only ones for treatment of sensitive cultural resources on public property, but they are the most commonly employed and realistic choices. These options are not mutually exclusive, and all three or various combinations thereof may be applicable within a single project with multiple resources.

For the Justiceburg Reservoir wildlife mitigation area, nine sites have been assessed as eligible for listing on the National Register of Historic Places. The treatment of these nine sites must be given due consideration and the cultural resources must be incorporated into the long-term management plan for the wildlife mitigation area. For now, however, only a few recommendations are offered since the specific details of the development of this area are not yet known.

\section{Recommendation No. 1}

It is recommended that any ground-disturbing activities be avoided in or in the immediate vicinity of the one National Register-eligible and eight unknown eligibility sites. These cultural resources and their locations should be taken into consideration during the development of the management plan for the wildlife mititation area. It is likely that any ground-disturbing impacts to sites, from either crop planting, fencing, or facilities construction, can be easily avoided.

\section{Recommendation No. 2}

National Register-eligible site 41GR586 and unknown eligibility site 41 GR600 are considered to be particularly sensitive since they contain highly visible artifacts and features that will attract vandalism. It is not feasible to attempt to hide either of these fragile resources. Since these sites and another site of unknown eligibility, 41GR599, are clustered together near a major spring, it is recommended that an area which includes all three sites be fenced and placed off-limits to public access. Occasional monitoring of this area is also recommended. It is further recommended that the caretaker's residence and associated buildings be located near the site cluster and adjacent to or within the fenced compound so that it might further deter unauthorized access to this sensitive area. In addition, more-detailed documentation of these sensitive archeological sites should be completed prior to the design and construc- tion of a fenced caretaker's complex. Detailed transit maps should be completed to better define the extent of each site. These maps should be tied to the engineering plan maps and should include topographic data, modern features and disturbances, and archeological features, artifacts, etc. This work should give special attention to accurately mapping the site boundaries so that all impacts might be avoided. Several shovel tests will probably be needed to determine the extent of the buried deposits. Controlled surface collection (e.g., by grid unit or piece plotting) and analysis of the displaced artifacts in the eroded portions of the sites are needed to better define the site age and cultural affiliation.

\section{Recommendation No. 3}

The other six unknown eligibility sites (41GR582 through 41GR585, 41GR587, and 41GR589) have low to moderate archeological visibility. Two of these sites (41GR587 and 41GR589) are of very low visibility and will not require any special consideration beyond occasional monitoring. The other four sites (41GR582 through 41GR585) are moderatevisibility sites clustered in the proximity of a major spring area. They are not so highly visible that they are extremely sensitive, yet they are obvious enough to be subject to some vandalism impacts if public access is unrestricted and unmonitored. It is recommended that the entire area including all of these sites be fenced so that public access can be restricted to some degree (e.g., no nature trails or hunting) and that the sites be monitored occasionally. Perhaps the area(s) could be designated as something like a "habitat study area" so that only short-term access by a few individuals would be permitted.

\section{Recommendation No. 4}

It is recommended that the cultural resources be incorporated into the long-term management plan for the wildlife mitigation area. This plan should include, but not be limited to, the above protective measures. It should also include options that would further protect and enhance the value of the cultural resources. At historic site 41GR586, additional photographic documentation and scale drawings of the intact chimney and well features are warranted. Stabilization of these features may be needed at some point in the future. If capping of the well is required by safety laws, it should be done in such a way that 
the well's historic integrity is not destroyed. At prehistoric site 41GR600, some consideration should be given to protective measures that could slow or halt the headward gully erosion in the central portion of the site. In addition, the possibility of incorporating the cultural resources into some type of interpretive public display should be considered.

\section{Summary of Recommendations}

The above recommendations offer some degree of protection to all nine of the significant sites (evaluated as National Register eligible or unknown eligibility) in the wildlife mitigation area. Grounddisturbing activities should be avoided at all nine of these sites, and public access to these resources should be controlled and limited to some extent. In addition, special protective measures should be given to the most highly sensitive sites. These recommen- dations are considered to be adequate to protect these important, nonrenewable resources, and it is felt that if these recommendations are implemented, they will not significantly alter or detract from the overall wildlife mitigation plan. In fact, these recommendations should be rather easy to implement within the framework of an overall management plan and may even serve to enhance the primary mission of providing undisturbed wildlife habitat by limiting public access to two of the three major spring areas. The third major spring area is perhaps the most scenic, and since it does not conflict with any sensitive archeological resources, it is the most likely choice for a nature trail or a scenic and/or picnic area. It should also be emphasized that, if properly managed and protected, significant cultural resources (such as historic site 41GR586 and prehistoric site 41GR600) can be developed into important public attractions. 


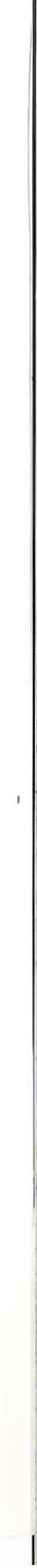




\section{REFERENCES CITED}

Abbott, James T.

1990 Geomorphic and Geoarcheological Investigations. Chapter 4 in Phase II Investigations at Prehistoric and Rock Art Sites, Justiceburg Reservoir, Garza and Kent Counties, Texas, by Douglas K. Boyd, James T. Abbott, William A. Bryan, Colin M. Garvey, Steve A. Tomka, and Ross C. Fields, pp. 23-62. Reports of Investigations No. 71, Volume I. Prewitt and Associates, Inc., Austin.

Alexander, Robert K.

1982 Archeological Site Reconnaissance in the Proposed Justiceburg Reservoir Area, Garza County, Texas. Grand River Consultants, Inc., Grand Junction, Colorado.

Banks, Larry D.

1990 From Mountain Peaks to Alligator Stomachs: A Review of Lithic Sources in the Trans-Mississippi South, the Southern Plains, and Adjacent Southwest. Memoir No. 4. Oklahoma Anthropological Society, Norman.

Barnes, Virgil E. (project director)

1967 Geologic Atlas of Texas, Lubbock Sheet. Bureau of Economic Geology, The University of Texas at Austin.

Bettis, E. Arthur, III

1984 New Conventions for the Designation of Soil Horizons and Layers. Plains Anthropologist 29:57-59.

Binford, Lewis R.

1980 Willow Smoke and Dog's Tails: Hunter-Gatherer Settlement Systems and Archaeological Site Formation. American Antiquity 45(1):4-20.

Birkeland, Peter W.

1984 Soils and Geomorphology. Oxford University Press, New York.
Blair, W. Frank

1950 The Biotic Provinces of Texas. Texas Journal of Science 2(1):93-117.

Blum, Michael D.

1989 Geoarcheological Investigations. Chapter 7 in Phase I Cultural Resources Investigations at Justiceburg Reservoir on the Double Mountain Fork of the Brazos River, Garza and Kent Counties, Texas, Vol. I, by Douglas K. Boyd, Martha Doty Freeman, Michael D. Blum, Elton R. Prewitt, and J. Michael Quigg, pp. 81-106. Reports of Investigations No. 66. Prewitt and Associates, Inc., Austin.

Bomar, George W.

1983 Texas Weather. University of Texas Press, Austin.

Boyd, Douglas K., James T. Abbott, William A. Bryan, Colin M. Garvey, Steve A. Tomka, and Ross C. Fields

1990 Phase II Investigations at Prehistoric and Rock Art Sites, Justiceburg Reservoir, Garza and Kent Counties, Texas. 2 vols. Reports of Investigations No. 71. Prewitt and Associates, Inc., Austin.

Boyd, Douglas K., Martha Doty Freeman, Michael D. Blum, Elton R. Prewitt, and J. Michael Quigg

1989 Phase I Cultural Resources Investigations at Justiceburg Reservoir on the Double Mountain Fork of the Brazos River, Garza and Kent Counties, Texas. 2 vols. Reports of Investigations No. 66. Prewitt and Associates, Inc., Austin.

Boyd, Douglas K., Steve A. Tomka, Ross C. Fields, and Elton R. Prewitt

1990 Research Design for Phase III Cultural Resources Investigations at Justiceburg Reservoir. Submitted to the City of Lubbock, Texas, by Prewitt and Associates, Inc., Austin. 
Campbell, Robert G.

1975 Archaeological Reconnaissance of Portions of the South Plains Planning Region. Report No. 1 . Texas Tech University, Lubbock.

1977 Archaeological Reconnaissance of Portions of the South Plains Planning Region. Report No. 2: Corrections and Additions. Texas Tech University, Lubbock.

Campbell, Robert G., and Sharon J. Judd

1977a Archaeological Reconnaissance of Portions of the South Plains Planning Region. Report No. 3: Tabulation of Archaeological Sites and Materials. Department of Anthropology, Texas Tech University, Lubbock.

1977b Archaeological Reconnaissance of Portions of the South Plains Planning Region. Report No. 4: Analysis of Archaeological Materials. Department of Anthropology, Texas Tech University, Lubbock.

Caran, S. Christopher, and Robert W. Baumgardner, Jr.

1988 The Lingos Formation, Western Rolling Plains of Texas. In Decade of North American Geology: Geological Society of America, South-Central Section, Centennial Field Guidebook 4:287-291. Edited by O. T. Hayward.

Dibble, David S., and Dessamae Lorrain

1968 Bonfire Shelter: A Stratified Bison Kill Site, Val Verde County, Texas. Miscellaneous Papers No.

1. Texas Memorial Museum, Austin.

Freeman, Martha Doty

1990a Natural Resources Exploitation and Development of Buffalo Hunting on the Rolling Plains, 18741879. Chapter 2 in Phase II Historical Investigations at Justiceburg Reservoir, Garza and Kent Counties, Texas, by Martha Doty Freeman and Douglas K. Boyd, pp. 5-48. Reports of Investigations No. 72. Prewitt and Associates, Inc., Austin.

1990b Agriculture in Texas: Ranching on the Western Rolling Plains, 1877-1945. Chapter 3 in Phase II Historical Investigations at Justiceburg Reservoir, Garza and Kent Counties, Texas, by Martha Doty Freeman and Douglas K. Boyd, pp. 49-97. Reports of Investigations No. 72. Prewitt and Associates, Inc., Austin.

1990c Outline of Property Types and National Register Assessments. Chapter 5 in Phase II Historical
Investigations at Justiceburg Reservoir, Garza and Kent Counties, Texas, by Martha Doty Freeman and Douglas K. Boyd, pp. 115-131. Reports of Investigations Ne. 72. Prewitt and Associates, Inc., Austin.

Freeman, Martha Doty, and Douglas K. Boyd

1990 Phase II Historical Investigations at Justiceburg Reservoir, Garza and Kent Counties, Texas. Reports of Investigations No. 72. Prewitt and Associates, Inc., Austin.

Garza County, Texas

Deed Records

Goodyear, Albert C., L. Mark Raab, and Timothy C. Klinger 1978 The Status of Archaeological Research Design in Cultural Resource Management. American Antiquity 43(2):159-173.

Gustavson, Thomas C. (editor)

1986 Geomorphology and Quaternary Stratigraphy of the Rolling Plains, Texas Panhandle. Guidebook 22. Bureau of Economic Geology, The University of Texas at Austin.

Gustavson, Thomas C., and William W. Simpkins

1989 Geomorphic Processes and Rates of Retreat Affecting the Caprock Escarpment, Texas Panhandle. Reports of Investigations No. 180. Bureau of Economic Geology, The University of Texas at Austin.

Hayden, Brian

1986 Resource Models of Inter-Assemblage Variability. Lithic Technology 15(3):82-89.

1987 Reply to Conaty. Lithic Technology 16(2-3):62.

Headstream, Mary Ellen

1990 Interview with Mary Ellen Headstream, August 25, 1990, Abilene, Texas, by Martha Doty Freeman.

Hendrix, John M.

1941 Texas Cow-Towns: Colorado City. The Cattleman 27(April):29-48, 53.

Holliday, Vance T., and Curtis M. Welty

1981 Lithic Tool Resources of the Eastem Llano Estacado. Bulletin of the Texas Archeological Society 52:201-214.

Howard, Calvin D.

1975 A Study of the Clear Fork Gouge. Bulletin of the Texas Archeological Society 44(for 1973):51-60. 
Hughes, David T.

1977 Analysis of Certain Prehistoric Bison Kills in the Texas Panhandle and Adjacent Areas. Master's thesis, University of Arkansas, Fayetteville.

Jones, Mrs. J. Lee, and O. W. Cline

1940 Frontier Days in Mitchell County and Colorado City. West Texas Historical Association Year Book 16(October):28-60.

Jones, Mrs. J. Lee, and Rupert N. Richardson

1943 Colorado City, the Cattlemen's Capital. West Texas Historical Association Year Book 19 (October):36-63.

Judd, Sharon J.

1977 Prehistoric Cultural Resources in the Central Llano Estacado and Western Rolling Plains of Texas. Master's thesis, Department of Anthropology, Texas Tech University, Lubbock.

Kelly, Robert L.

1980 Hunter-Gatherer Settlement Systems. Unpublished Master's thesis, Department of Anthropology, University of New Mexico, Albuquerque.

1983 Hunter-Gatherer Mobility Strategies. Journal of Anthropological Research 39(3):277-306.

Leonhardy, Frank C.

1966 Test Excavations in the Mangum Reservoir Area of Southwestern Oklahoma. Contributions of the Museum of the Great Plains, No. 2. Lawton, Oklahoma.

Mallouf, Robert J.

1981 A Case Study of Plow Damage to Chert Artifacts: The Brookeen Creek Cache, Hill County, Texas. Office of the State Archeologist Report No. 33. Texas Historical Commission, Austin.

Maryland Historical Trust

1987 How to Use Historic Contexts in Maryland: A Guide for Survey, Registration, Protection and Treatment Projects. Maryland Historical Trust, n.p.

Pass, Fred

1981 Texas Almanac and State Industrial Guide, 1982-1983. A. H. Belo, Dallas.

Richardson, Wayne E., Darrell G. Grice, and Lee A. Putnam 1975 Soil Survey of Garza County, Texas. U.S. Department of Agriculture, Soil Conservation Service, in cooperation with the Texas Agricultural Experiment Station.
Runkles, Frank A.

1964 The Garza Site: A Neo-American Campsite near Post, Texas. Bulletin of the Texas Archeological Society 35:101-125.

Scurry County, Texas

Probate Files

Snyder Daily News, The

Soil Survey Staff

1975 Soil Taxonomy: A Basic System of Soil Classification for Making and Interpreting Soil Surveys. Soil Conservation Service, U.S. Department of Agriculture, Washington, D.C.

Sollberger, J. B.

1971 A Technological Study of Beveled Knives. Plains Anthropologist 16(53):209-218.

Spring, Mrs. Bruce, and Vera Nowotny

n.d. Marriage Records, 1846-1874. Guadalupe County, Texas. Typescript copy in the Texas State Library and Archives, Austin.

Suhm, Dee Ann, and Edward B. Jelks

1962 Handbook of Texas Archeology: Type Descriptions. Texas Archeological Society Special Publication No. 1 and Texas Memorial Museum Bulletin No. 4. Austin.

Texas. General Land Office

1873 Fannin Scrip File 6076. Abstract 58. H\&GN Railway Company. Patented to original, December 27,1873 .

1933 Garza County. File 59305. Abstract 988. H\&GN Railway Company Certificate Number 6/1034. Patented to Will Williams, March 7, 1933.

1939a Garza County. File 59304. Abstract 987. H\&GN Railway Company Certificate Number 6/1035. Patented to Will Williams, October 17, 1939.

1939b Garza County. File 59306. Abstract 990. H\&GN Railway Company Certificate Number 6/1038. Patented to Will Williams, October 17, 1939.

Tumer, Ellen S., and Thomas R. Hester

1985 A Field Guide to Stone Artifacts of Texas Indians. Texas Monthly Press, Austin. 


\section{U.S. Bureau of the Census}

1880 Guadalupe County, Texas.

1900 Garza County, Texas.

1910 Garza County, Texas.

U.S. Department of the Interior, National Park Service, National Register Division

1982 How to Apply the National Register Criteria for Evaluation. National Park Service, Department of the Interior, Washington, D.C.

Wendorf, Fred, and James J. Hester

1975 Late Pleistocene Environments of the Southern
High Plains. Fort Burgwin Research Center Report No. 9. Southem Methodist University, Dallas.

Willey, Patrick S., and Jack T. Hughes

1978 The Deadman's Shelter Site. In Archeology at McKenzie Reservoir, edited by Jack T. Hughes and Patrick S. Willey, pp. 149-190. Archeological Survey Report No. 24. Texas Historical Commission, Austin.

Williams, William Wayne, and John Ward

1987 Interview with William Wayne Williams and John Ward, May 27, 1987, in Justiceburg, Texas, by Martha Doty Freeman. 


\title{
APPENDIX: Geologic Profile Descriptions
}

\author{
C. Britt Bousman
}


Zone

Depth $(\mathrm{cm})$

41GR600 (cutbank)

1

$0-0.5$

2

$0.5-15$

3

$15-30$

4

$30-60+$

Profile 1 (roadcut)

1

$0-35$.

2

$35-60 / 75$

3

$60 / 75$

Profile 2 (backhoe trench, 41GR598)

1

$0-2$

2

2-20

3

20-40
Description

Yellow (10YR 7/6) loose sand, wind blown, forms light discontinuous deposit over surface of site, extremely abrupt smooth lower boundary, $\mathrm{C}$ horizon.

Dark grayish brown (10YR 4/2) friable loam, weak coarse subangular blocky structure, fire-cracked rocks, cobbles, pebbles, lithic artifacts, charcoal, bones, and mussel shells observed, few to common insect burrows, clear smooth lower boundary, midden deposit, Ab horizon.

Brown (10YR 5/3) friable silt loam with weak coarse subangular blocky structure, friable white $\mathrm{CaCO}^{3}$ concretions, many insect burrows, few pebbles, gradual smooth lower boundary, Bkb horizon.

White (10YR $8 / 2)$ calcareous silt loam with moderate fine granular structure, lower boundary not observed, weathered bedrock, $\mathrm{K}$ horizon.

Brown (7.5YR 5/4) friable sand with common $\mathrm{CaCO}^{3}$ concretions, abrupt smooth lower boundary, Ak horizon.

Light brownish gray to gray (10YR $6 / 2$ to $5 / 1$ ) clay loam with strong medium blocky structure, few $\mathrm{CaCO}^{3}$ concretions, abrupt wavy lower boundary, $2 \mathrm{Bkb}$ horizon.

Stratified sandstone bedrock with $\mathrm{CaCO}^{3}$ skin on upper surface, $\mathrm{R}$ horizon.

Brown (7.5YR 5/4) friable sandy loam, few roots and rootlets, few insect burrows, mud cracks on top surface, very abrupt wavy lower boundary, A horizon.

Strong brown (7.5YR 5/6) friable sandy loam, fewer roots and rootlets, common $\mathrm{CaCO}^{3}$ concretions, gradual smooth lower boundary, Bwk1 horizon.

Strong brown (7.5YR 5/6) sandy loam, many small $\mathrm{CaCO}^{3}$ concretions, few roots and rootlets, rare small decomposing sandstone cobbles, gradual smooth lower boundary, Bwk2 horizon. 
Zone

4

Depth (cm)

$40-60$

5

$60-70+$

\section{Description}

Strong brown (7.5YR 5/6.5) sandy loam, $\mathrm{CaCO}^{3}$ concretions frequencies increase down-profile, rare roots and rootlets, small to large common sandstone cobbles, abrupt irregular lower boundary, Bwk3 horizon.

Brown to light olive brown (7.5YR 5/4 to 2.5 Y 5/4) silt loam with moderate fine crumb structure, interlocking sandstone slabs and quartzite pebbles, many $\mathrm{CaCO}^{3}$ concretions and skins on rocks and pebbles, lower boundary not observed, Bk4 horizon.

Brown (10YR 4/3) silt loam, common roots and rootlets, dense surface grass cover, abrupt wavy lower boundary, A horizon.

Dark brown (10YR 3/3) firm clay loam with moderate medium subangular blocky structure with sand on ped faces, common rootlets, rare roots, few fine very faint strong brown (7.5YR 5/6) mottles, gradual smooth lower boundary, 2Btb1 horizon.

3

$30-60$

4

$60-75$

5

75-94

6

94-100+

Profile 4 (backhoe trench)

1

$0-9$

2

9-55
Very dark grayish brown (10YR 3/2) firm clay loam, moderate medium blocky structure, few rootlets and roots, very small quartzite pebbles, ped faces have pressure surfaces, few medium faint strong brown (7.5YR 5/6) mottles, gradual smooth lower boundary, 2Btb2 horizon.

Very dark grayish brown to strong brown (10YR $3 / 2$ to $7.5 \mathrm{YR} 5 / 6$ ) very firm clay loam, moderate medium blocky structure, few small quartzite pebbles, clear smooth lower boundary, 2Btb3 horizon.

Strong brown (7.5YR 5/8) firm clay loam with moderate medium subangular blocky structure, common $\mathrm{CaCO}^{3}$ concretions, rare roots and rootlets, very abrupt wavy lower boundary, 3Btb horizon.

Brownish yellow (10YR 6/6) friable sandstone bedrock, $R$ horizon.
Strong brown (7.5YR 4/6) friable to firm loam, common rootlets, moderate surface grass cover, clear smooth lower boundary, A horizon.

Reddish brown (5YR 4/4) firm clay loam with moderate medium subangular blocky structure, well-formed pressure faces, very small quartzite pebbles, few rootlets, gradual smooth lower boundary, 2Btb1 horizon. 
Zone

3

Depth (cm)

$55-74$

4

74-85+

Profile 5 (backhoe trench)

1

$0-50$

2

$50-61$

3

61-87

4

$87-90$

5

90-100+

Profile 6 (backhoe trench)

1

$0-15$

2

3

$57-75$

4

$75-77+$

Profile 7 (backhoe trench, 41GR582)

1

$0-30$

2

\section{Description}

Yellowish red (5YR 5/6) very firm clay loam with moderate medium subangular blocky structure, abrupt irregular lower boundary, 2Btb2 horizon.

Pink (5YR 8/4) $\mathrm{CaCO}^{3}$ with crumb structure and small quartzite pebbles, $2 \mathrm{~K}$ horizon.

Yellowish brown (10YR 5/6) silty sand, common rootlets, few $\mathrm{CaCO}^{3}$ concretions, large sandstone slab in bottom of zone, very abrupt irregular lower boundary, Ap horizon.

White (10YR 8/1) $\mathrm{CaCO}^{3}$ deposit, abrupt very irregular lower boundary, $\mathrm{K}$ horizon.

Brownish yellow (10YR 6/6) silty sand, abundant $\mathrm{CaCO}^{3}$ concretions, abrupt irregular lower boundary, $\mathrm{Ck}$ horizon.

White (N8) $\mathrm{CaCO}^{3}$ layer, abrupt irregular lower boundary, $\mathrm{K}$ horizon.

Yellowish brown (10YR 5/6) decomposed sandstone, R horizon.

Strong brown (7.5YR 4/6) loam, light grass cover, mud cracks on surface, few roots and insect burrows, clear smooth lower boundary, Ap horizon.

Yellowish red (5YR 4/6) silt loam, common thin $\mathrm{CaCO}^{3}$ filaments throughout, abrupt irregular lower boundary, Bk horizon.

White (N8) $\mathrm{CaCO}^{3}$ concretions and skins, abrupt irregular lower boundary, $\mathrm{K}$ horizon.

Yellow (10YR 7/6) sandstone bedrock, R horizon.

Strong brown (7.5YR 4/6) loam, moderate grass cover, mud cracks on surface, few roots, rootlets, and insect burrows, common quartzite pebbles on surface and in sediments, fire-cracked rock at $23 \mathrm{~cm}$, abrupt irregular lower boundary, A horizon.

Pinkish white (7.5YR 8/2) $\mathrm{CaCO}^{3}$ cementing pebbles, gravels, and small cobbles, $\mathrm{K}$ horizon. 
Zone

Depth (cm)

Profile 8 (backhoe trench)

1

2

3

$50-190$

4

190-200+

Profile 9 (backhoe trench)

1

$0-45$

2

$45-80$

3

$80-100+$

Profile 10 (backhoe trench, 41GR597)

1

$0-15$

2

$15-30$

3

$30-75$

4

75-100+

\section{Description}

Light yellowish brown (10YR 6/4) silty sand, light surface grass cover, mud cracks on surface, common quartzite and quartz pebbles on surface and buried, gradual smooth lower boundary, Ac horizon.

Light brown (7.5YR 6/4) silty sand, common quartzite pebbles and gravels, light $\mathrm{CaCO}^{3}$ films and filaments throughout, fire-cracked rock at $30 \mathrm{~cm}$, clear smooth lower boundary, Ck1 horizon.

Reddish yellow (7.5YR 7/6) silty sand, common $\mathrm{CaCO}^{3}$ concretions, quartzite pebbles, gravels, and cobbles, $\mathrm{Ck} 2$ horizon.

Reddish yellow (5YR 6/6) oxidized gravel, no matrix, 2C horizon.

Strong brown (7.5YR 4/6) loam, moderate surface grass cover, many quartzite pebbles on surface and buried, common rootlets, gradual smooth lower boundary, Ap horizon.

Strong brown (7.5YR 5/6) loam with slightly more silt than overlying zone, very thin dispersed $\mathrm{CaCO}^{3}$ filaments, few rootlets and roots, abrupt irregular lower boundary, Bk horizon.

Pink (7.5YR 8/4) $\mathrm{CaCO}^{3}$-cemented gravel, $2 \mathrm{Ck}$ horizon.

Strong brown (7.5YR 4/6) sandy loam, moderate surface grass cover, common roots and rootlets, common quartzite pebbles, clear smooth lower boundary, Ap horizon.

Brown (7.5YR 4/4) sandy loam, common rootlets, few $\mathrm{CaCO}^{3}$ filaments, common quartzite pebbles, rare snail shells, diffuse lower boundary, Ak horizon.

Strong brown (7.5YR 5/6) loam, common $\mathrm{CaCO}^{3}$ filaments, common quartzite gravels that increase in frequency down-profile, abrupt wavy lower boundary, Bk horizon.

Pinkish white (7.5YR 8/2) $\mathrm{CaCO}^{3}$-cemented gravels in a loam matrix, 2Ck horizon. 
Zone

Depth (cm)

Profile 11 (backhoe trench, 41GR601)

1

$0-44$

2

$44-100$

3

$100-120+$

Profile 12 (backhoe trench, 41GR603)

1

0-14

2

14-35

3

$35-70$

4

$70-100+$
Description

Strong brown (7.5YR 5/6) friable sandy loam, light surface grass cover, common $\mathrm{CaCO}^{3}$ concretions (ca. $<5 \mathrm{~cm}$ diameter) and filaments, few roots, few quartzite pebbles, disturbed by plowing, small chert core on surface, clear smooth lower boundary, Ap horizon.

Strong brown (7.5YR 5/6) sandy loam, common small $\mathrm{CaCO}^{3}$ concretions, very abrupt irregular lower boundary, $\mathrm{Ck}$ horizon.

Light gray (10YR 7/2) decomposing friable sandstone bedrock, $R$ horizon.

Yellowish red (5YR 4/6) friable sandy loam, moderate grass cover, common rootlets and insect burrows, common lithic artifacts on surface, few quartzite pebbles in zone, gradual smooth lower boundary, Ap horizon.

Dark brown (7.5YR 4/4) friable loam, few rootlets, rare quartzite pebbles, gradual smooth lower boundary, A horizon.

Reddish brown (5YR 4/4) loam, common $\mathrm{CaCO}^{3}$ flecks, small burrows at bottom contact, abrupt irregular lower boundary, Bk horizon.

Reddish yellow (7.5YR 8/6) quartzite gravels cemented with $\mathrm{CaCO}^{3}$ in a silty sand matrix, $2 \mathrm{Ck}$ horizon.

Yellowish red (5YR 5/6) friable sandy loam, thin discontinuous pebble-gravel lenses, abrupt wavy to smooth lower boundary, C horizon.

Yellowish red (5YR 5/6) sandy loam, thin $\mathrm{CaCO}^{3}$ filaments, clear smooth lower boundary, $2 \mathrm{Ck}$ horizon.

Yellowish red (5YR 5.5/6) loam with moderate coarse subangular blocky structure, few $\mathrm{CaCO}^{3}$ filaments, common quartzite pebbles and granules, thin ( $1 \mathrm{~cm}$ thick) wavy discontinuous ash lenses at ca. $115 \mathrm{~cm}$, diffuse lower boundary, 3Btkb horizon. 
Zone

Depth (cm)

4

$160-240+$

Profile 14 (backhoe trench, 41GR481)

1

$0-10$

2

$10-70$

3

70-95

4

95-100+

Profile 15 (backhoe trench)

1

$0-5$

2

$5-51$

3

$51-80$

4

$80-100+$

\section{Description}

Yellowish red (5YR 5/6) silty sand, few $\mathrm{CaCO}^{3}$ filaments, discontinuous pebbles lenses with distinct gravel lens at $190 \mathrm{~cm}, 3 \mathrm{Ckb}$ horizon.

Brown (7.5YR 5/4) loose sandy loam, light surface grass cover, common rootlets, common quartzite pebbles and gravels, clear smooth lower boundary, Ap horizon.

Strong brown (7.5YR 4/6) sandy loam, common quartzite pebbles and gravels, $\mathrm{CaCO}^{3}$ filaments and concretions increase downprofile, $\mathrm{CaCO}^{3}$ skins on gravels, clear smooth lower boundary, $\mathrm{Bk} 1$ horizon.

Strong brown (7.5YR 5/6) sandy loam, very many quartzite pebbles and gravels, $\mathrm{CaCO}^{3}$ skins on gravels, very abrupt wavy lower boundary, $\mathrm{Bk} 2$ horizon.

Pinkish white (7.5YR 8/2) pebbles and gravel cemented by $\mathrm{CaCO}^{3}$, 2Ck horizon.

Brown (7.5YR 5/4) loose sandy loam, light surface grass cover, common rootlets, few small $\mathrm{CaCO}^{3}$ concretions, clear smooth lower boundary, Ak horizon.

Dark brown (7.5YR 4.5/4) friable sandy loam, common small $\mathrm{CaCO}^{3}$ concretions, few rootlets and rodents burrows, abrupt highly irregular lower boundary, Bk horizon.

Light yellowish brown (10YR 6/4) friable sandy loam, large interlocking sandstone slabs, common large $\mathrm{CaCO}^{3}$ concretions, few rootlets and roots, clear irregular lower boundary, $\mathrm{Ck}$ horizon.

Pale yellow (2.5Y 7/4) friable sand, decomposing sandstone bedrock, common $\mathrm{CaCO}^{3}$ concretions, $\mathrm{R}$ horizon.

Dark yellowish brown (10YR 4/4) friable sandy loam, thick surface grass cover, many rootlets, clear smooth lower boundary, Ap horizon. 
Zone

2

4

5

6
Depth (cm)

$5-40$

$40-50$

$50-90$

$90-155$

$155+$
Description

Dark brown (7.5YR 3/2) slightly firm loam, common $\mathrm{CaCO}^{3}$ concretions, charcoal at $18 \mathrm{~cm}$, common rootlets, few insect burrows, rare quartzite pebbles, gradual smooth lower boundary, Ak horizon.

Strong brown (7.5YR 4/6) firm loam, common $\mathrm{CaCO}^{3}$ concretions, few rootlets and quartzite pebbles, gradual smooth lower boundary, Bk horizon.

Yellowish red (5YR 5/6) firm clay loam, many small $\mathrm{CaCO}^{3}$ concretions, few rootlets, diffuse smooth lower boundary, 2Btkb1 horizon.

Dark reddish brown (5YR 3/4) firm clay loam with moderate fine subangular blocky to crumb structure, very many $\mathrm{CaCO}^{3}$ concretions, rare rootlets, very abrupt smooth lower boundary, $2 \mathrm{Btkb} 2$ horizon.

Yellow (2.5Y 8/6) $\mathrm{CaCO}^{3}, 2 \mathrm{~K}$ horion. 


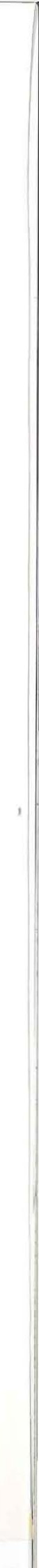




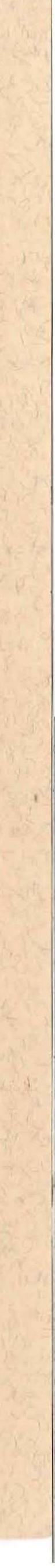

